\title{
Extension of use of nicotinamide riboside chloride as a novel food pursuant to Regulation (EU) 2015/2283
}

\author{
EFSA Panel on Nutrition, Novel Foods and Food Allergens (NDA),
} Dominique Turck, Torsten Bohn, Jacqueline Castenmiller, Stefaan De Henauw, Karen Ildico Hirsch-Ernst, Alexandre Maciuk, Inge Mangelsdorf, Harry J McArdle, Androniki Naska, Carmen Pelaez, Kristina Pentieva, Alfonso Siani, Frank Thies, Sophia Tsabouri, Marco Vinceti, Francesco Cubadda, Thomas Frenzel, Marina Heinonen, Miguel Prieto Maradona, Rosangela Marchelli, Monika Neuhäuser-Berthold, Morten Poulsen, Josef Rudolf Schlatter, Henk van Loveren, Océane Albert, Agnès de Sesmaisons Lecarré and Helle Katrine Knutsen

\begin{abstract}
Following a request from the European Commission, the EFSA Panel on Nutrition, Novel Foods and Food Allergens (NDA) was asked to deliver an opinion on the safety of an extension of use of the novel food (NF) nicotinamide riboside chloride (NRC) pursuant to Regulation (EU) 2015/2283. The assessment addresses the use of NRC in 'meal replacement products' and 'nutritional drink mixes' at levels up to $300 \mathrm{mg} /$ day for the general population, and in food for special medical purposes (FSMP) and total diet replacement for weight control (TDRWC) (as per Regulation (EU) No 609/2013) at levels up to $500 \mathrm{mg} /$ day in adults. Benchmark dose modelling was carried out on data from the 90-day oral toxicity studies in rats relevant to the safety assessment. Considering the lack of tolerable upper intake level (UL) for nicotinamide in infants and the narrow margin of exposure between the estimated intake in infants and the lower confidence bound of the benchmark doses $\left(\mathrm{BMDL}_{05}\right)$ estimated by the models, the Panel concludes that the safety of the NF has not been established for use in 'meal replacement products' and 'nutritional drink mixes' under the proposed conditions of use. For FSMP and TDRWC, the proposed maximum use level corresponds to an intake of $210 \mathrm{mg}$ nicotinamide per day, which is below the current UL for nicotinamide of $900 \mathrm{mg} /$ day for adults. The Panel considers that the NF is as safe as pure nicotinamide for use in FSMP and TDRWC. The Panel, however, notes experimental data which indicate several pathways by which intakes of nicotinamide (or its precursors), at levels that are substantially higher than the physiological requirement, might cause adverse effects. The Panel considers that further investigations are required and that a re-evaluation of the UL for nicotinamide may be warranted.
\end{abstract}

(C) 2021 European Food Safety Authority. EFSA Journal published by John Wiley and Sons Ltd on behalf of European Food Safety Authority.

Keywords: nicotinamide, nicotinamide riboside chloride, niacin, novel food, nutrient source, extension of use

Requestor: European Commission

Question number: EFSA-Q-2020-00289

Correspondence: nda@efsa.europa.eu 
Panel members: Dominique Turck, Torsten Bohn, Jacqueline Castenmiller, Stefaan De Henauw, Karen Ildico Hirsch-Ernst, Helle Katrine Knutsen, Alexandre Maciuk, Inge Mangelsdorf, Harry J McArdle, Androniki Naska, Carmen Pelaez, Kristina Pentieva, Alfonso Siani, Frank Thies, Sophia Tsabouri and Marco Vinceti.

Declarations of interest: The declarations of interest of all scientific experts active in EFSA's work are available at https://ess.efsa.europa.eu/doi/doiweb/doisearch.

Suggested citation: EFSA NDA Panel (EFSA Panel on Nutrition, Novel Foods and Food Allergens), Turck D, Bohn T, Castenmiller J, De Henauw S, Hirsch-Ernst KI, Maciuk A, Mangelsdorf I, McArdle HJ, Naska A, Pelaez C, Pentieva K, Siani A, Thies F, Tsabouri S, Vinceti M, Cubadda F, Frenzel T, Heinonen $M$, Prieto Maradona M, Marchelli R, Neuhäuser-Berthold M, Poulsen M, Schlatter JR, van Loveren $H$, Albert O, de Sesmaisons Lecarré A and Knutsen HK, 2021. Scientific Opinion on the extension of use of nicotinamide riboside chloride as a novel food pursuant to Regulation (EU) 2015/2283. EFSA Journal 2021;19(11):6843, 47 pp. https://doi.org/10.2903/j.efsa.2021.6843

ISSN: $1831-4732$

(C) 2021 European Food Safety Authority. EFSA Journal published by John Wiley and Sons Ltd on behalf of European Food Safety Authority.

This is an open access article under the terms of the Creative Commons Attribution-NoDerivs License, which permits use and distribution in any medium, provided the original work is properly cited and no modifications or adaptations are made.

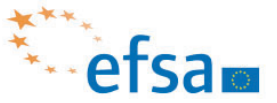

The EFSA Journal is a publication of the European Food Safety Authority, a European agency funded by the European Union.

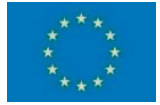




\section{Table of contents}

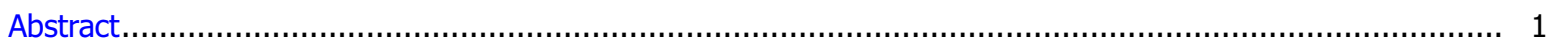

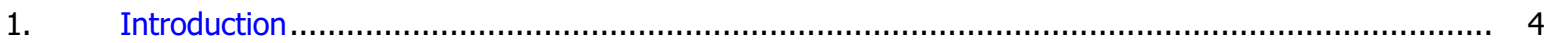

1.1. Background and Terms of Reference as provided by the European Commission .......................... 4

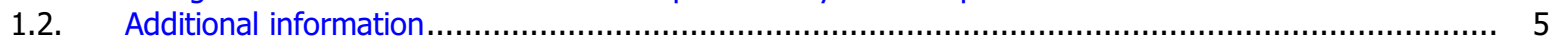

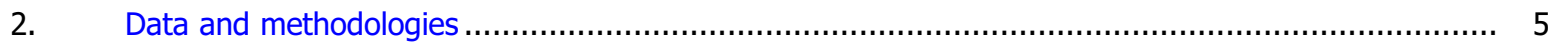

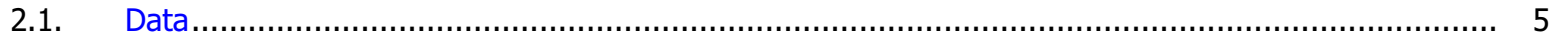

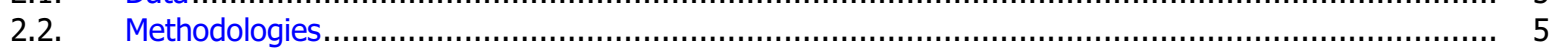

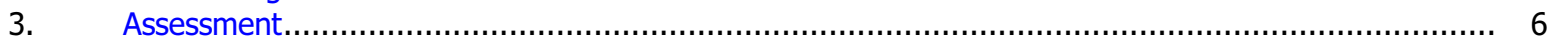

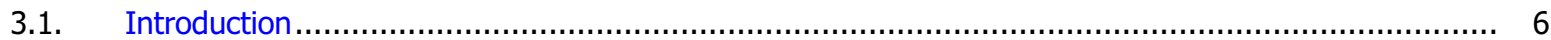

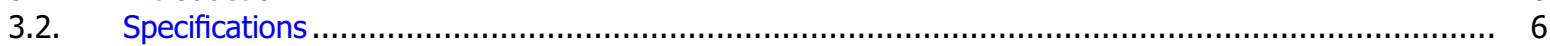

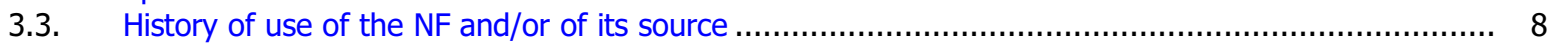

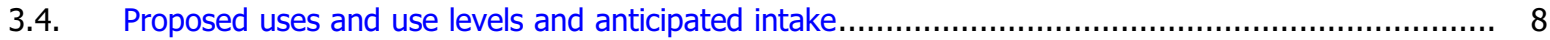

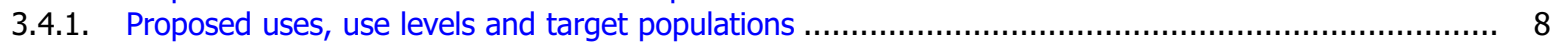

3.4.1.1. Food for special medical purposes (FSMP) as defined by Regulation (EU) No 609/2013 ................ 8

3.4.1.2. Total Diet Replacement for Weight Control (TDRWC) as defined by Regulation (EU) No 609/2013..... 9

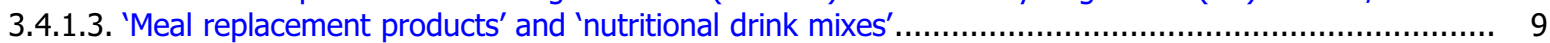

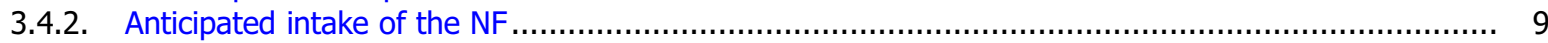

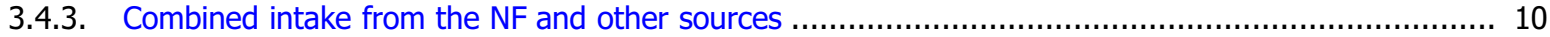

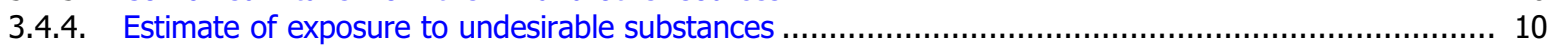

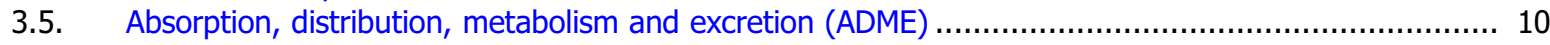

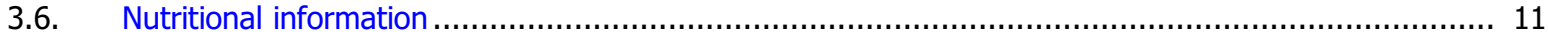

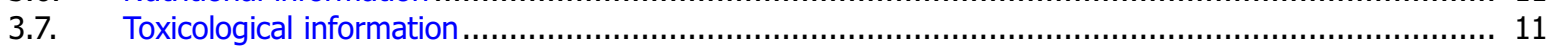

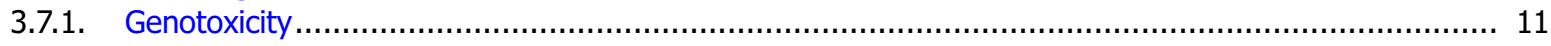

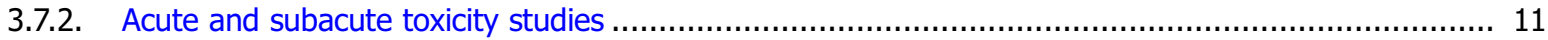

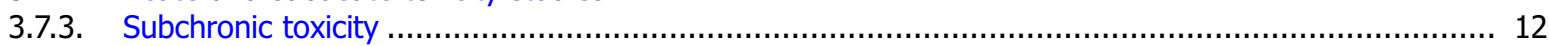

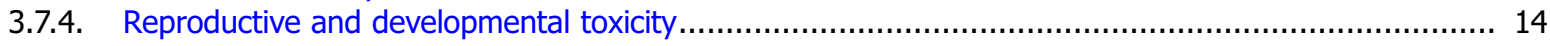

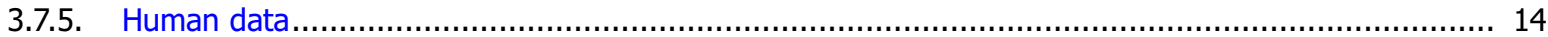

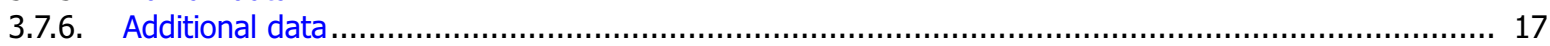

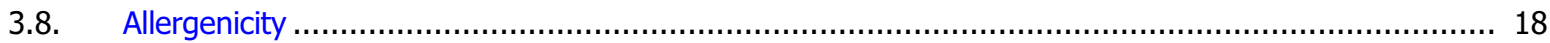

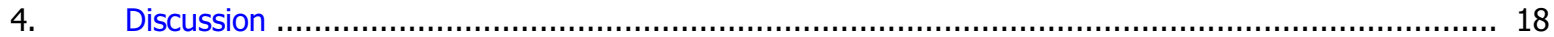

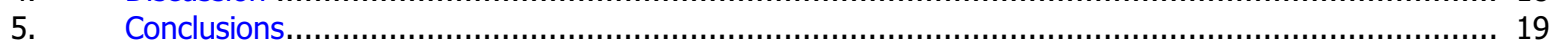

5.1. Protection of Proprietary data in accordance with Article 26 of Regulation (EU) $2015 / 2283 \ldots \ldots \ldots \ldots . . .20$

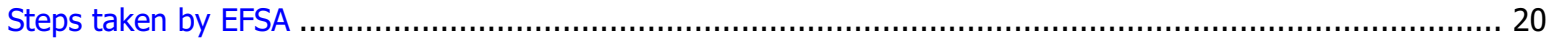

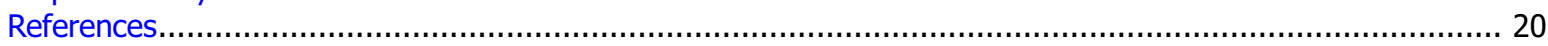

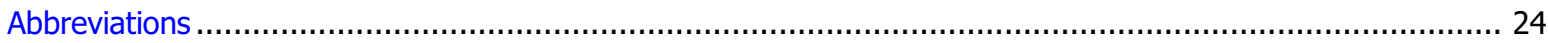

Appendix A - Overview of toxicological studies on the NF....................................................... 25

Appendix $B$ - Literature search on health effects of the intake of nicotinamide riboside chloride, nicotinamide

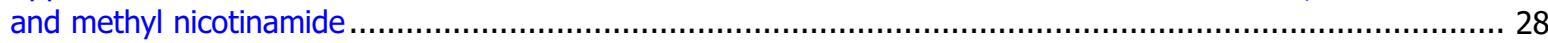

Appendix C - Animal experiments on nicotinamide effect on chemical- and UV-induced tumours.................. 35

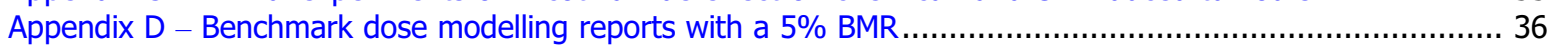




\section{Introduction}

\subsection{Background and Terms of Reference as provided by the European Commission}

The European Union legislation lists nutritional substances that may be used for nutritional purposes in certain categories of foods as sources of certain nutrients.

The relevant Union legislative measures are:

- Regulation (EU) 2015/2283 of the European Parliament and of the Council on novel foods. ${ }^{1}$

- Directive 2002/46/EC of the European Parliament and of the Council lays down requirements on food supplements. ${ }^{2}$

- Regulation (EU) No 609/2013 of the European Parliament and of the Council on food intended for infants and young children, food for special medical purposes, and total diet replacement for weight control. ${ }^{3}$

- Regulation (EC) 1925/2006 on the addition of vitamins and mineral and of certain other substances to foods. ${ }^{4}$

Nicotinamide riboside chloride has been authorised for placing on the Union market as a novel food by Commission Implementing Regulation (EU) 2020/16 for use as a source of niacin in food supplements for the general adult population. ${ }^{5}$ On 2 March 2020, the company ChromaDex Inc. submitted a request to the European Commission to change the conditions of use of the novel food nicotinamide riboside chloride within the meaning of Article 10(1) of Regulation (EU) 2015/2283.

The application requested to extend the use of nicotinamide riboside chloride in additional food categories as follows: food for special medical purposes as defined by Regulation (EU) No 609/2013; total diet replacement for weight control as defined by Regulation (EU) No 609/2013; meal replacement products; and nutritional drink mixes.

The applicant has also requested data protection under Article 26 of Regulation (EU) 2015/2283.

In accordance with Article 29(I)(a) of Regulation (EC) No 178/20026, the European Commission asks EFSA to provide a scientific opinion:

- by carrying out the assessment for an extension of use of nicotinamide riboside chloride as a novel food in accordance with Article 10(3) of Regulation (EU) 2015/2283;

- following the outcome of the novel food assessment, by evaluating the safety and bioavailability of nicotinamide riboside chloride when added for nutritional purposes as a source of niacin to food for special medical purposes, total diet replacement for weight control and food for the general population, in the context of Regulation (EU) No 609/2013 and Regulation (EC) No 1925/2006.

In addition, the European Food Safety Authority is requested to include in its scientific opinion a statement as to if, and if so to what extent, the proprietary data for which the applicant is requesting data protection was used in elaborating the opinion in line with the requirements of Article 26(2)(c) of Regulation (EU) 2015/2283.

\footnotetext{
${ }^{1}$ Regulation (EU) 2015/2283 of the European Parliament and of the Council of 25 November 2015 on novel foods, amending Regulation (EU) No 1169/2011 of the European Parliament and of the Council and repealing Regulation (EC) No 258/97 of the European Parliament and of the Council and Commission Regulation (EC) No 1852/2001.

2 Directive 2002/46/EC of the European Parliament and of the Council of 10 June 2002 on the approximation of the laws of the Member States relating to food supplements.

3 Regulation (EU) No 609/2013 of the European Parliament and of the Council of 12 June 2013 on food intended for infants and young children, food for special medical purposes, and total diet replacement for weight control and repealing Council Directive 92/52/EEC, Commission Directives 96/8/EC, 1999/21/EC, 2006/125/EC and 2006/141/EC, Directive 2009/39/EC of the European Parliament and of the Council and Commission Regulations (EC) No 41/2009 and (EC) No 953/2009.

${ }^{4}$ Regulation (EC) No 1925/2006 of the European Parliament and of the Council of 20 December 2006 on the addition of vitamins and minerals and of certain other substances to foods.

${ }^{5}$ Commission Implementing Regulation (EU) 2020/16 of 10 January 2020 authorising the placing on the market of nicotinamide riboside chloride as a novel food under Regulation (EU) 2015/2283 of the European Parliament and of the Council and amending Commission Implementing Regulation (EU) 2017/2470.

${ }^{6}$ Regulation (EC) No 178/2002 of the European Parliament and of the Council of 28 January 2002 laying down the general principles and requirements of food law, establishing the European Food Safety Authority and laying down procedures in matters of food safety.
} 


\subsection{Additional information}

In 2019, the NDA Panel established the safety of nicotinamide riboside chloride as a novel food pursuant to Regulation (EU) $2015 / 2283$ for use in food supplements for the adult population, and the bioavailability of nicotinamide from this source, in the context of Directive 2002/46/EC (EFSA NDA Panel, 2019). The European Commission authorised the placing on the market of nicotinamide riboside chloride on 10 January $2020 .^{7}$

In 2002, the Scientific Committee on Food (SCF) published an opinion on the Tolerable Upper Intake level (UL) for niacin [nicotinic acid (NA) and nicotinamide (NAM)] (EFSA, 2006). An UL of $900 \mathrm{mg} /$ day was established for NAM for adults, excluding pregnant and lactating women in view of the lack of data for these population groups.

In 2014, the NDA Panel published an opinion on dietary reference values for niacin (EFSA NDA Panel, 2014).

\section{Data and methodologies}

\subsection{Data}

Administrative and scientific requirements for NF applications referred to in Article 10 of Regulation (EU) 2015/2283 are listed in the Commission Implementing Regulation (EU) 2017/2469 .

A common and structured format on the presentation of NF applications is described in the EFSA guidance on the preparation and presentation of an NF application (EFSA NDA Panel, 2016). As indicated in this guidance, it is the duty of the applicant to provide all of the available (proprietary, confidential and published) scientific data (including both data in favour and not in favour) that are pertinent to the safety of the NF.

The assessment of the safety of the NF at the new proposed uses and use levels is based on the data provided by the applicant and the scientific opinion on the safety of nicotinamide riboside chloride (NRC) as a novel food pursuant to Regulation (EU) 2015/2283 and bioavailability of nicotinamide from this source, in the context of Directive 2002/46/EC (EFSA NDA Panel, 2019).

The safety assessment of this NF is based on data supplied in the application and information submitted by the applicant following EFSA's requests for supplementary information.

During the assessment, the Panel identified additional data which were not included in the application, by means of a literature search following a search strategy and standard operating procedure as described by the University of Chemistry and Technology of Prague (Dibusz and Vejvodova, 2020).

This NF application includes a request for protection of proprietary data in accordance with Article 26 of Regulation (EU) 2015/2283. The data requested by the applicant to be protected comprise a human study evaluating the safety and dose-dependent effects of NRC supplementation in generally healthy adults aged $\geq 55$ years (Maki et al., 2020).

\subsection{Methodologies}

The assessment follows the methodology set out in the EFSA guidance on NF applications (EFSA NDA Panel, 2016) and the principles described in the relevant existing guidance documents from the EFSA Scientific Committee. The legal provisions for the assessment are laid down in Article 11 of Regulation (EU) 2015/2283 and in Article 7 of the Commission Implementing Regulation (EU) 2017/2469.

Additional information which was not included in the application was retrieved by literature search following a search strategy and standard operating procedure as described by UCT Prague (Dibusz and Vejvodova, 2020).

This assessment concerns only the risks that might be associated with consumption of the NF under the proposed conditions of use and is not an assessment of the efficacy of the NF with regard to any claimed benefit.

\footnotetext{
7 Commission Implementing Regulation (EU) 2020/16 of 10 January 2020 authorising the placing on the market of nicotinamide riboside chloride as a novel food under Regulation (EU) 2015/2283 of the European Parliament and of the Council and amending Commission Implementing Regulation (EU) 2017/2470. OJ L7, 13.1.2020.

8 Commission Implementing Regulation (EU) 2017/2469 of 20 December 2017 laying down administrative and scientific requirements for applications referred to in Article 10 of Regulation (EU) 2015/2283 of the European Parliament and of the Council on novel foods. OJ L 351, 30.12.2017, pp. 64-71.
} 
The evaluation of bioavailability of the nutrient niacin from the source nicotinamide riboside chloride was conducted in line with the principles contained in the 'Guidance on safety evaluation of sources of nutrients and bioavailability of nutrient from the sources' (EFSA ANS Panel, 2018).

\section{Assessment}

\subsection{Introduction}

The NF which is the subject of the application is nicotinamide riboside chloride, a synthetic form of nicotinamide riboside. The NF is proposed to be used as a source of niacin. Niacin is a generic term for nicotinic acid (NA) and nicotinamide (NAM), which are water-soluble organic compounds that belong to the group of B vitamins (EFSA NDA Panel, 2014).

The NF falls under the following category, as defined in Art. 3 of Regulation (EU) 2015/2283: ix) Vitamins, minerals and other substances used in accordance with Directive 2002/46/EC, Regulation (EC) No 1925/2006 and Regulation (EU) No 609/2013.

On 7 August 2019, the EFSA NDA Panel concluded that nicotinamide riboside chloride is safe to be used in food supplements for the healthy adult population, pursuant to Regulation (EU) 2015/2283. In the present application, the applicant seeks to extend the use of the NF to four food categories, i.e. foods for special medical purposes (FSMP) and total diet replacement products for weight control (TDRWC), as defined by Regulation (EU) No 609/2013, as well as 'meal replacement products' and 'nutritional drink mixes'. The target population for these products is the adult population, excluding pregnant and lactating women. The applicant indicates that the products are not intended to be consumed by children.

The NF under assessment is identical to the previously evaluated NF. There is no change regarding the production process and compositional data of the NF.

In its previous evaluation, the Panel concluded that the NF is likely to be absorbed mainly as NAM following hydrolysis in the gut based on the data on absorption, distribution, metabolism and elimination available in mice, rats, dogs and humans. If a fraction of the NF were absorbed intact, it would be expected to be rapidly metabolised to NAM in the blood. Upon absorption, the NF contributes to the NAM body pool, i.e. acts as a precursor of NAD ${ }^{+}$in cells and is primarily metabolised in the liver to 1-methylnicotinamide (1-MNM) through methylation and subsequently to N-methyl-2pyridone-carboxamide and $\mathrm{N}$-methyl-4-pyridone-carboxamide, following oxidation. These metabolites are then excreted in the urine. The Panel confirmed the bioavailability of nicotinamide, a form of niacin, from that source, in the context of Directive 2002/46/EC (EFSA NDA Panel, 2019).

No concerns regarding genotoxicity of the NF were identified by the Panel in its previous evaluation, considering available genotoxicity studies (Appendix $A$ ) and the nature of the NF.

A no observed adverse effect level (NOAEL) of $300 \mathrm{mg} / \mathrm{kg}$ bw per day was derived from the available repeated dose toxicity studies with rats and dogs conducted with the NF. Reproductive and developmental toxicity studies in rats were also provided, from which the Panel derived an NOAEL for fertility and reproductive performance of $675 \mathrm{mg} / \mathrm{kg}$ bw per day in males and $1,088 \mathrm{mg} / \mathrm{kg}$ bw per day in females and an NOAEL for maternal and embryo/fetotoxicity of $325 \mathrm{mg} / \mathrm{kg}$ bw per day (Appendix A).

One single-dose pharmacokinetic study and four clinical trials conducted in healthy adult subjects (NRC doses from $100 \mathrm{mg}$ for 1 day up to $2,000 \mathrm{mg} /$ day for up to 12 weeks) were provided. Findings from these studies did not raise safety concerns.

The proposed maximum use level in food supplements was $300 \mathrm{mg} /$ day (i.e. $4.3 \mathrm{mg} / \mathrm{kg}$ bw in a $70-$ $\mathrm{kg}$ adult). In the light of the human data available on nicotinamide riboside chloride and nicotinamide, the Panel considered that the margin of exposure $(\mathrm{MoE})$ of 70 was sufficient for the adult population, excluding pregnant and lactating women. An NOAEL of $325 \mathrm{mg} / \mathrm{kg}$ bw per day for maternal and embryo/fetotoxicity was identified from reproductive and developmental toxicity studies in rats. In the absence of data which could justify accepting an MoE lower than 100 for pregnant and lactating women, the Panel concluded that an intake of $230 \mathrm{mg} / \mathrm{day}$ of the NF was safe for these two population groups. The European Commission authorised the placing on the market of nicotinamide riboside chloride on 10 January $2020 .^{7}$

\subsection{Specifications}

The specifications proposed by the applicant are indicated in Table 1. In addition to the specifications currently authorised as per the Union List, ${ }^{7}$ the specifications include maximum levels for 
mercury, cadmium and lead. No maximum levels for heavy metals are established for the food categories which are the subject of this application (Commission Regulation (EC) No 1881/2006 ${ }^{9}$ ).

Table 1: Specifications of the NF

Description: The novel food is a synthetic form of nicotinamide riboside. The novel food contains $\geq \mathbf{9 0 \%}$ nicotinamide riboside chloride, predominantly in its $\beta$ form, the remaining components being residual solvents, reaction by-products and degradation products.

Nicotinamide riboside chloride:

CAS number: 23111-00-4

EC number: 807-820-5

IUPAC name: 1-[(2R,3R,4S,5R)-3,4-dihydroxy-5-(hydroxymethyl)oxolan-2-yl]pyridin-1-ium-3-

carboxamide;chloride

Chemical formula: C11H15N205CI

Molecular weight: $290.7 \mathrm{~g} / \mathrm{mol}$

\begin{tabular}{|c|c|c|}
\hline Parameter & Specification & Method of analysis \\
\hline Colour & White to Light Brown & Visual \\
\hline Form & Powder & Visual \\
\hline Identification & Conforms by NMR & NMR \\
\hline Nicotinamide riboside chloride & $\geq 90$ wt $\%$ & HPLC-UV* \\
\hline Water content & $\leq 2.0 \%$ & Karl Fischer Titration (USP < $921>$ )* \\
\hline \multicolumn{3}{|l|}{ Residual solvents } \\
\hline Acetone & $\leq 5,000 \mathrm{mg} / \mathrm{kg}$ & GC Headspace (USP < $467>$ ) \\
\hline Methanol & $\leq 1,000 \mathrm{mg} / \mathrm{kg}$ & GC Headspace (USP < $467>$ ) \\
\hline Acetonitrile & $\leq 50 \mathrm{mg} / \mathrm{kg}$ & GC Headspace (USP < $467>$ ) \\
\hline Methyl tert-butyl ether & $\leq 500 \mathrm{mg} / \mathrm{kg}$ & GC Headspace (USP < $467>$ ) \\
\hline \multicolumn{3}{|l|}{ Reaction by-products } \\
\hline Methyl acetate & $\leq 1,000 \mathrm{mg} / \mathrm{kg}$ & GC Headspace (USP < $467>$ ) \\
\hline Acetamide & $\leq 27 \mathrm{mg} / \mathrm{kg}$ & GC-FID* \\
\hline Acetic acid & $\leq 5,000 \mathrm{mg} / \mathrm{kg}$ & GC-FID* \\
\hline \multicolumn{3}{|l|}{ Heavy metals } \\
\hline Arsenic & $\leq 1 \mathrm{mg} / \mathrm{kg}$ & ICP-MS (USP $<232>,<233>,<2232>$ ) \\
\hline Mercury & $\leq 0.1 \mathrm{mg} / \mathrm{kg}$ & ICP-MS (USP $<232>,<233>,<2232>$ ) \\
\hline Cadmium & $\leq 1 \mathrm{mg} / \mathrm{kg}$ & ICP-MS (USP $<232>,<233>,<2232>$ ) \\
\hline Lead & $\leq 0.5 \mathrm{mg} / \mathrm{kg}$ & ICP-MS (USP $<232>,<233>,<2232>$ ) \\
\hline \multicolumn{3}{|l|}{ Microbiological limits } \\
\hline Total plate count & $\leq 1000 \mathrm{CFU} / \mathrm{g}$ & $\mathrm{AOAC}$ or equivalent \\
\hline Yeast and mould & $\leq 100 \mathrm{CFU} / \mathrm{g}$ & AOAC or equivalent \\
\hline Escherichia coli & Absent $/ 10 \mathrm{~g}$ & AOAC or equivalent \\
\hline
\end{tabular}

AOAC: Association of Analytical Communities; CFU: colony forming units; GC: gas chromatography; GC-FID: gas chromatography coupled with a flame ionisation detector; HPLC-UV: high-performance liquid chromatography-ultraviolet spectroscopy; ICP-MS: inductively coupled plasma mass spectrometry; NMR: nuclear magnetic resonance; USP: United States Pharmacopeia.

*: In-house validated analytical methods.

Although the average nicotinamide riboside chloride purity of the NF is approximately $96 \%$ at the time of production, a specification of not less than $90 \%$ has been set to account for the degradation of nicotinamide riboside chloride over the course of shelf-life. Specifications have also been set to control the amounts of residual solvents, reaction by-products and heavy metals. Forced degradation studies indicate that during shelf-life, NF-containing products will accumulate small amounts of NAM, ribose and chloride.

The Panel previously concluded that the information provided on the specifications of the NF was sufficient and did not raise safety concerns (EFSA NDA Panel, 2019).

\footnotetext{
${ }^{9}$ Commission Regulation (EC) No 1881/2006 of 19 December 2006 setting maximum levels for certain contaminants in foodstuffs.
} 


\subsection{History of use of the NF and/or of its source}

The NF has a generally recognised as safe (GRAS) status in the USA since 2016 for addition to vitamin waters, protein shakes, nutrition bars, gum and chews, as a source of niacin. ${ }^{10}$ The intended maximum use level is $0.027 \%$ by weight. It was also filed to the U.S. Food and Drug Administration as a new dietary ingredient (NDI) for use in dietary supplements in 2015 (daily dose: $180 \mathrm{mg}$ ), without objection ${ }^{11}$; the NDI status was updated in 2017 with new proposed intake level (daily dose $300 \mathrm{mg}$ ) and product specifications. ${ }^{12}$

In 2018, the NF was included in the Licensed Natural Health Products Database (LNHPD) by Health Canada. ${ }^{13}$

The NF is authorised for use in food supplements on the EU market as of January $2020 .^{7}$

\subsection{Proposed uses and use levels and anticipated intake}

\subsubsection{Proposed uses, use levels and target populations}

The applicant applies for an extension of authorised conditions of use for the NF to the four food categories described below.

\subsubsection{Food for special medical purposes (FSMP) as defined by Regulation (EU) No 609/2013}

The applicant intends to use the NF as a source of niacin in FSMP, as defined in Article 2.2(g) of Regulation (EU) No 609/2013 14 and further regulated by Commission delegated Regulation (EU) No 2016/128. ${ }^{15}$ The proposed maximum use level in FSMP is $500 \mathrm{mg}$ of the NF per day. The applicant indicates that the extension of use covers products for adults only. Children, pregnant and lactating women are excluded.

Commission delegated Regulation (EU) $2016 / 128^{16}$ stipulates a limit of maximum $3 \mathrm{mg}$ Niacin Equivalent (NE) per $100 \mathrm{kcal}$ in products defined as per Art 2(1)(a), i.e. 'nutritionally complete food with a standard nutrient formulation which, used in accordance with the manufacturer's instructions, may constitute the sole source of nourishment for the persons for whom it is intended'. Products defined as per Art 2(1)(b), i.e. 'nutritionally complete food with a nutrient-adapted formulation specific for a disease, disorder or medical condition which, used in accordance with the manufacturer's instructions, may constitute the sole source of nourishment for the persons for whom it is intended' and Art 2(1)(c), i.e. 'nutritionally incomplete food with a standard formulation or a nutrient-adapted formulation specific for a disease, disorder or medical condition which is not suitable to be used as the sole source of nourishment' shall comply with the maximum amounts of vitamins and mineral substances as specified in Annex I, Part B of Regulation (EU) 2016/128, without prejudice to modifications for one or more of these nutrients rendered necessary by the intended use of the product.

${ }^{10}$ GRAS No 635, available at https://www.accessdata.fda.gov/scripts/fdcc/index.cfm?set=GRASNotices\&id=635

11 NDIN 882, available at https://www.regulations.gov/document?D=FDA-2015-S-0023-0087

12 NDIN 1062, available at https://www.regulations.gov/document?D=FDA-2018-S-0023-0032

13 NPN 80088977, available at https://health-products.canada.ca/Inhpd-bdpsnh/info.do?licence $=80088977$

${ }^{14}$ Regulation (EU) No 609/2013 of the European Parliament and of the Council of 12 June 2013 on food intended for infants and young children, food for special medical purposes, and total diet replacement for weight control and repealing Council Directive 92/52/EEC, Commission Directives 96/8/EC, 1999/21/EC, 2006/125/EC and 2006/141/EC, Directive 2009/39/EC of the European Parliament and of the Council and Commission Regulations (EC) No 41/2009 and (EC) No 953/2009. OJ L 181, 29.6.2013.

15 Commission Delegated Regulation (EU) 2016/128 of 25 September 2015 supplementing Regulation (EU) No 609/2013 of the European Parliament and of the Council as regards the specific compositional and information requirements for food for special medical purposes. OJ L 25, 2.2.2016.

16 Commission Delegated Regulation (EU) 2016/128 of 25 September 2015 supplementing Regulation (EU) No 609/2013 of the European Parliament and of the Council as regards the specific compositional and information requirements for food for special medical purposes [https://eur-lex.europa.eu/legal-content/EN/ALL/?uri=CELEX\%3A32016R0128]. 


\subsubsection{Total Diet Replacement for Weight Control (TDRWC) as defined by Regulation (EU) No 609/2013}

The applicant intends to use the NF in TDRWC, as defined in Article 2.2(h) of Regulation (EU) No $609 / 2013^{17}$ and further regulated by Commission delegated Regulation (EU) No 2017/1798 ${ }^{18}$. The proposed maximum use level in TDRWC is $500 \mathrm{mg}$ of the NF per day. As defined by Regulation (EU) No 609/2013, TDRWC are intended for healthy overweight or obese adults who intend to achieve weight reduction.

\subsubsection{3. 'Meal replacement products' and 'nutritional drink mixes'}

The applicant intends to use the NF as an ingredient in 'meal replacement products' and 'nutritional drink mixes' at a proposed maximum use level of $300 \mathrm{mg} /$ day.

The target population proposed by the applicant is adults only, excluding children, pregnant and lactating women. However, as the NF is intended to be used as an ingredient in standard food categories, it cannot be excluded that the NF would also be consumed by other groups of the population. Therefore, the safety data and the exposure assessment shall cover all population groups (Commission Implementing Regulation (EU) 2017/2469, article 5(6) ${ }^{19}$ ).

The applicant indicates that 'meal replacement products' are foods presented as a replacement for one or more meals of the daily diet. The applicant notes that indication as meal replacement for weight control is subject to the conditions of use of two health claims authorised under the provisions of Regulation (EC) No 1924/2006 20 .

The applicant indicates that 'nutritional drink mixes' are intended primarily as nutritional supplement to the daily diet of elderly people.

\subsubsection{Anticipated intake of the NF}

On the basis of the proposed uses and use levels (Sections 3.4.1), the Panel considers the following maximum anticipated intake of the NF for the safety evaluation:

- $300 \mathrm{mg} /$ day from meal replacement products or nutritional drink mixes for the general population, including infants, children, pregnant and lactating women.

- $500 \mathrm{mg} /$ day from FSMP or TDRWC for adult consumers of these products, excluding pregnant and lactating women.

Estimated maximum intake of nicotinamide riboside chloride in children, relative to body weight (bw), is presented in Table 2.

Table 2: Estimated maximum intake of nicotinamide riboside chloride in children, relative to body weight, from meal replacement products or nutritional drink mixes

\begin{tabular}{l|c|c}
\hline & $\begin{array}{c}\text { Mean body } \\
\text { weight }^{(\mathbf{a})} \mathbf{( \mathbf { k g } )}\end{array}$ & $\begin{array}{c}\text { Nicotinamide riboside chloride intake } \\
\text { (b) }\end{array}$ \\
\hline Infants, < 1 year & 5 & 60 \\
\hline Toddlers, 1-2 years & 12 & 25 \\
\hline Other children, 3-9 years & 23 & 13 \\
\hline Adolescents, 10-13 years & 43 & 7 \\
\hline Adolescents, 14-18 years & 61 & 5 \\
\hline
\end{tabular}

17 Regulation (EU) No 609/2013 of the European Parliament and of the Council of 12 June 2013 on food intended for infants and young children, food for special medical purposes and total diet replacement for weight control and repealing Council Directive 92/52/EEC, Commission Directives 96/8/EC, 1999/21/EC, 2006/125/EC and 2006/141/EC, Directive 2009/39/EC of the European Parliament and of the Council and Commission Regulations (EC) No 41/2009 and (EC) No 953/2009. OJ L 181, 29.6.2013.

${ }^{18}$ Commission Delegated Regulation (EU) 2017/1798 of 2 June 2017 supplementing Regulation (EU) No 609/2013 of the European Parliament and of the Council as regards the specific compositional and information requirements for total diet replacement for weight control. OJ L 259, 7.10.2017.

${ }^{19}$ Commission Implementing Regulation (EU) 2017/2469 of 20 December 2017 laying down administrative and scientific requirements for applications referred to in Article 10 of Regulation (EU) 2015/2283 of the European Parliament and of the Council on novel foods. C/2017/8874. OJ L 351, 30.12.2017, p. 64-71.

${ }^{20}$ Regulation (EC) No 1924/2006 of the European Parliament and of the Council of 20 December 2006 on nutrition and health claims made on foods. OJ L 404, 30.12.2006, p. 9-25. 
(a): Mean body weight of children (males and females) for each age group reported in the Scientific Committee Guidance on selected default values to be used by the EFSA Scientific Committee, Scientific Panels and Units in the absence of actual measured data (EFSA Scientific Committee, 2012). EFSA Journal 2012;10(3):2579.

(b): Considering a maximum intake of $300 \mathrm{mg} /$ day.

\subsubsection{Combined intake from the NF and other sources}

The Panel previously concluded that the contribution of nicotinamide riboside from food sources other than the NF is too small to be relevant for the safety assessment (EFSA NDA Panel, 2019).

Doses of 300 and $500 \mathrm{mg} /$ day of the NF would deliver $126 \mathrm{mg}$ and $210 \mathrm{mg}$ nicotinamide per day, respectively, under the assumption that the NF is fully metabolised (see Section 3.5).

Mean intakes of niacin from the background diet were estimated to range from 42.2 to $50.1 \mathrm{mg}$ niacin equivalents ${ }^{21}(\mathrm{NE})$ per day in adult men and $27.5-35.5 \mathrm{mg} \mathrm{NE} /$ day in adult women, across EU countries (EFSA NDA Panel, 2014). Estimates of 95th percentile intakes were up to $78.2 \mathrm{mg} \mathrm{NE} /$ day in adult men. Mean total niacin intakes ranged from 8 to $11 \mathrm{mg} \mathrm{NE} /$ day in infants, from 12 to $20 \mathrm{mg}$ $\mathrm{NE} /$ day in toddlers (1-2 years), from 14 to $32 \mathrm{mg} \mathrm{NE} /$ day in other children aged 3-9 years and from 25 to $41 \mathrm{mg} \mathrm{NE}$ /day in adolescents aged 10-17 years. Estimates of 95th percentile intakes were up to $24 \mathrm{mg} \mathrm{NE} /$ day in male infants and $34 \mathrm{mg} \mathrm{NE} /$ day in male toddlers. These estimates were calculated considering the food contents of preformed niacin (i.e. NAM and NA) as well as of tryptophan (i.e. tryptophan content divided by a factor of 60 ).

\section{4,4. Estimate of exposure to undesirable substances}

The applicant provided estimates of the maximum exposure to potential degradants of NRC, i.e. furfural, ribose and chloride, based on the results of stability studies (Table 3 ).

Table 3: Estimated exposure to NRC's degradants

\begin{tabular}{|c|c|c|c|}
\hline \multirow[b]{2}{*}{ Substance } & \multirow[b]{2}{*}{ Conditions } & \multicolumn{2}{|c|}{ Exposure estimate (mg/day) } \\
\hline & & $\begin{array}{c}\text { For } 300 \mathrm{mg} \text { of } \\
\text { the NF }\end{array}$ & $\begin{array}{c}\text { For } 500 \mathrm{mg} \text { of } \\
\text { the NF }\end{array}$ \\
\hline \multirow[t]{3}{*}{ Furfural } & $\begin{array}{l}\text { Assuming } 0.16 \% \mathrm{w} / \mathrm{w} \text { after } 24 \text { months storage } \\
\left(25^{\circ} \mathrm{C} / 60 \% \mathrm{RH}\right)\end{array}$ & 0.5 & 0.8 \\
\hline & $\begin{array}{l}\text { Assuming } 0.32 \% \mathrm{w} / \mathrm{w} \text { after storage in accelerated } \\
\text { conditions (worst case scenario) }\end{array}$ & 1.9 & 3.2 \\
\hline & $\begin{array}{l}\text { Assuming } 7 \%\left(\%^{(a)} \text { of NRC degraded into equimolar }\right. \\
\text { amounts of free nicotinamide, ribose and chloride }\end{array}$ & 10.5 & 17.5 \\
\hline Chloride & $\begin{array}{l}\text { Assuming } 7 \%^{(a)} \text { of NRC degraded into equimolar } \\
\text { amounts of free nicotinamide, ribose and chloride }\end{array}$ & 2.1 & 3.5 \\
\hline
\end{tabular}

(a): Considering that the product may contain $90 \%$ NRC, $2 \%$ water, $1.25 \%$ residual solvents and reaction by-products, as per its specifications.

For the proposed maximum intake of the NF of $500 \mathrm{mg} /$ day, maximum intake estimates of $3.2 \mathrm{mg}$ furfural per day and $17.5 \mathrm{mg}$ ribose per day were estimated. These estimates are below the acceptable daily intake (ADI) for furfural of $0.5 \mathrm{mg} / \mathrm{kg}$ body weight/day (EFSA, 2004) and the maximum level of ribose of $36 \mathrm{mg} / \mathrm{kg}$ bw per day considered as safe (EFSA NDA Panel, 2018). The consumption of the NF under the proposed use levels does not contribute significantly to the overall exposure to chloride through the diet.

The Panel identifies no concern from the information provided on the exposure to undesirable substances under the new proposed conditions of use.

\subsection{Absorption, distribution, metabolism and excretion (ADME)}

A new human study, which assessed metabolic effects of NRC supplementation, was submitted as part of the present application (Remie et al., 2020) (see also Section 3.7.5). In a randomised, doubleblind, crossover design, 13 healthy overweight or obese participants (seven women; six men) received

\footnotetext{
${ }^{21}$ Values relate to niacin in the form of nicotinamide and nicotinic acid. Niacin can be synthesised in the human body from the indispensable amino acid tryptophan. $1 \mathrm{mg}$ niacin equivalent $(\mathrm{NE})=1 \mathrm{mg}$ nicotinamide $=1 \mathrm{mg}$ nicotinic acid $=60 \mathrm{mg}$ dietary tryptophan.
} 
a placebo or the NF at a dose of 1,000 mg/day for two periods of 6 weeks separated by 4-7 weeks of wash out. Skeletal muscle biopsies were taken at the end of each period. NAD ${ }^{+}$was amplified and quantified by a cycling assay involving alcohol dehydrogenase and malic acid (Kato et al., 1973) and related metabolites were quantified by mass spectrometry. No effect was observed on the concentration of $\mathrm{NAD}^{+}$of skeletal muscle $(\mathrm{n}=8)$. Compared to the control period, significant increases in the concentration of nicotinic acid adenine dinucleotide (NAAD), a precursor of $\mathrm{NAD}^{+}$ $(+677 \pm 155 \%, \mathrm{p}<0.01, \mathrm{n}=12)$ and of 1-MNM $(+299 \pm 62 \%, \mathrm{p}<0.01, \mathrm{n}=12)$, were observed at the end of the supplementation period. The concentrations of NADH, NADP, NADPH, nicotinamide adenosine mononucleotide and nicotinamide mononucleotide in muscle samples were not affected. Plasma levels of these metabolites were not measured. The Panel notes that, in contrast to the increase in plasma concentration of $\mathrm{NAD}^{+}$observed in human studies with daily supplementation of NRC (Airhart et al., 2017; Conze et al., 2019; EFSA NDA Panel, 2019), no effect was found on the $\mathrm{NAD}^{+}$concentration of muscle cells in this experiment in a small group of overweight and obese adults at a daily dose of $1,000 \mathrm{mg} \mathrm{NRC}$ for 6 weeks.

\subsection{Nutritional information}

No new information has been submitted by the applicant.

The Panel notes that, at the maximum use level of 300 and $500 \mathrm{mg} /$ day in the respective food categories, the NF would deliver 126 and $210 \mathrm{mg}$ NAM/day, respectively, under the assumption that nicotinamide riboside chloride is fully metabolised to NAM. This largely exceeds the physiological requirement for niacin (population reference intake (PRI) $=1.6 \mathrm{mg} \mathrm{NE} / \mathrm{MJ}$ per day ${ }^{22}$ ) for all population groups (EFSA NDA Panel, 2014).

In 2002, the SCF established an UL for NAM of $900 \mathrm{mg} /$ day $(12.5 \mathrm{mg} / \mathrm{kg}$ bw per day) for the adult population, excluding pregnant and lactating women (EFSA, 2006). ULs for toddlers, children and adolescents were extrapolated from the UL for adults based on body weight (Table 4).

Table 4: Tolerable upper intake level for nicotinamide

\begin{tabular}{l|c}
\hline Age (years) & UL for nicotinamide (mg per day) \\
\hline $1-3$ & 150 \\
\hline $4-6$ & 220 \\
\hline $7-10$ & 350 \\
\hline $11-14$ & 500 \\
\hline $15-17$ & 700 \\
\hline $18+($ excluding pregnant and lactating women) & 900 \\
\hline
\end{tabular}

Source: EFSA (2006)

The Panel notes that $300 \mathrm{mg}$ NRC per day would deliver $126 \mathrm{mg}$ nicotinamide per day, which is close to the UL for nicotinamide in toddlers of $150 \mathrm{mg} /$ day established by the SCF (EFSA, 2006). The Panel also notes that no UL for nicotinamide has been established for infants ( $<1$ year of age).

\subsection{Toxicological information}

Toxicological studies on the NF evaluated as part of the previous evaluation are summarised in Appendix A (EFSA NDA Panel, 2019).

\subsubsection{Genotoxicity}

No new data were submitted.

\subsubsection{Acute and subacute toxicity studies}

No new data were submitted.

\footnotetext{
${ }^{22}$ Niacin requirement is related to energy requirement and therefore expressed in $\mathrm{mg} N E / M J$. PRIs for niacin expressed in $\mathrm{mg}$ $\mathrm{NE} /$ day can be calculated based on the energy requirement of the population group considered, depending on the age, sex and physical activity level. See Appendices G, H, I and J of NDA Panel, 2014; available at: https://efsa.onlinelibrary.wiley.com/ doi/10.2903/j.efsa.2014.3759
} 


\subsubsection{Subchronic toxicity}

In the previous assessment of the NF (EFSA NDA Panel, 2019), the applicant provided a 90-day repeated dose toxicity study in the rat [Study No. 14022, unpublished, good laboratory practice (GLP), OECD TG 408; Bhoite et al., 2015; Conze et al., 2016]. Briefly, the NF was administered by oral gavage at doses of $0,300,1,000$ and $3,000 \mathrm{mg} / \mathrm{kg}$ bw per day to both male and female Sprague Dawley rats (10/sex per group) (Appendix A). One additional group was given NAM at $1,260 \mathrm{mg} / \mathrm{kg}$ bw per day (equimolar to $3,000 \mathrm{mg} / \mathrm{kg}$ bw per day of the NF). Lower body weights were noted in all male rats that received the test items compared to the control. At the time, the Panel noted that the effects were related to reduced food consumption and not very pronounced in the low and mid dose and were not considered as being adverse. Substance-related effects that were considered adverse by the Panel involved haematology endpoints, liver, kidneys, genital organs and the hormonal system. Effects were observed at 1,000 and $3,000 \mathrm{mg} / \mathrm{kg}$ bw per day, with a steep dose-response relationship. Histopathological examination also revealed adverse effects in several organs at 3,000 mg/kg bw per day. Notably, the same effects were observed in the group which received a dose of NAM of $1,260 \mathrm{mg} / \mathrm{kg}$ bw. An NOAEL of $300 \mathrm{mg} / \mathrm{kg}$ bw per day was identified from this study.

As part of the request for extension of uses, the applicant provided an additional GLP-, OECDcompliant 90-day subchronic rat toxicity study to the Panel on NRC produced by another company (Marinescu et al., 2020). The test substance used in the study is described as 'a synthetic, natureidentical nicotinamide riboside chloride (CAS \#23111-00-4) designated as NR-E manufactured using a proprietary process under the guidelines of good manufacturing practice (GMP) 21 CFR 111/210 (C.F.R. $\S 111$ (2007), C.F.R. $\S 210(1978))^{\prime}$. The test substance was not available to the applicant. To ascertain the nature of the test substance, the applicant compared the NF with NRC produced by the other company in its commercially available form, which is a combination with pterostilbene. The commercial combination was analysed by high-performance liquid chromatography (HPLC) and nuclear magnetic resonance (NMR). HPLC chromatograms were similar, although the impurities present in traces were not identified. The molecular identity of NRC was confirmed by ${ }^{1} \mathrm{H}$ and ${ }^{13} \mathrm{C}$ NMR and by ${ }^{1} \mathrm{H}^{-1} \mathrm{H}$ COSY (correlated spectroscopy) two-dimensional NMR. Both products are crystalline and of high purity. The Panel considers that the study from Marinescu et al. (2020) is relevant to the safety assessment of the NF.

In this study (Marinescu et al., 2020), Sprague Dawley rats were exposed to 0, 300, 500 or $1,200 \mathrm{mg} / \mathrm{kg}$ bw per day of synthetic NRC by daily oral gavage (10 per sex for each dose group) for 90 days, followed by a 28-day recovery for five rats per sex for each dose group.

There was no mortality in the study. Both males and females displayed a treatment-related decrease in body weight gain. The mean body weight was lower (statistically significant) in males from the high-dose group on day $92(-13 \%)$. The body weight difference persisted during the recovery period (not statistically significant). Decreases in food consumption and food efficiency were also observed in the high dose-treated male rats (not statistically significant).

A dose-dependent increase in mean relative brain, liver, kidney, adrenal and testis weights was reported for males on day 94 (statistically significant in the high-dose group for brain, liver, kidneys and adrenals). After recovery, a dose-dependent increase in mean relative testicular weight was reported (statistically significant in the high-dose group), while mean relative heart and kidney weights displayed a statistically significant increase in the high-dose group. In females, a dose-dependent increase in relative liver and kidney weights was observed (significant for liver in the high-dose group), as well as dose-dependent decreases in uterus and spleen weights. Trends were not maintained after recovery. Observations were consistent with those reported by Conze et al. (2016). The Panel, however, notes that the numerical values of the relative organ weights reported in the paper appear to be inflated, probably by a constant factor.

Clinical chemistry analyses revealed a decrease in plasma total cholesterol and triglyceride concentrations in all treated males, both before and after recovery, with statistical significance in the low- and high-dose groups as compared to controls. Although there was no dose response, due to the consistent occurrence in all treated males in combination with the increase in liver weight, the decrease in body weight gain and decreased food consumption and efficiency, the Panel considers these changes in blood lipids as treatment-related.

Haematological analysis revealed a decrease in white blood cell counts in all treated males reaching statistical significance after recovery in the high-dose group $(-30.5 \%)$, as well as a dose-related decrease in lymphocyte counts after recovery (reaching $-27.6 \%$ in the high-dose group; $p<0.05$ ). In all treated females, before recovery, both neutrophil and monocyte counts were increased, with 
stronger, statistically significant effects in the middle-dose group $(62.6 \%$ and $65 \%$ increases, respectively; $p<0.05)$. After recovery, neutrophil counts remained non-significantly increased in all dose groups. Considering the magnitude of the effects in the context of the large variability of the data and the absence of dose-response, the Panel considers these effects non-adverse.

Considering the decreased body weight and body weight gain in the high-dose male group as adverse effects of NRC, the authors identified an NOAEL of $500 \mathrm{mg} / \mathrm{kg}$ bw from the study.

The Panel considers that the study by Marinescu et al. (2020) shows similar findings to the study conducted with the NF (Bhoite et al., 2015; Conze et al., 2016), such as decreased body weights, increased relative liver and kidney weights and effects on the haematopoietic system. In light of this, the Panel reconsidered the validity of its conclusions regarding the adversity of the effect on body weight observed in the Conze study.

Table 5: Values for terminal body weight, relative kidney weight, relative liver weight from the 90day toxicity studies in rats on NRC - absolute mean \pm SD (percent change)

\begin{tabular}{|c|c|c|c|c|c|}
\hline \multicolumn{6}{|c|}{ Conze et al. (2016) } \\
\hline \multicolumn{2}{|c|}{ Dose (mg/kg bw per day) } & $\mathbf{0}$ & 300 & 1,000 & 3,000 \\
\hline \multirow[t]{3}{*}{ Males } & $\begin{array}{l}\text { Terminal body } \\
\text { weight }(\mathrm{g})\end{array}$ & $395.70 \pm 18.36$ & $\begin{array}{c}363.56 \pm 23.22 \\
(-8 \%)^{(a)}\end{array}$ & $\begin{array}{c}354.22 \pm 21.86 \\
(-10 \%)^{(a)}\end{array}$ & $\begin{array}{c}317.21 \pm 25.80 \\
(-20 \%)^{(a)}\end{array}$ \\
\hline & $\begin{array}{l}\text { Relative kidney } \\
\text { weight }\end{array}$ & $0.715 \pm 0.047$ & $\begin{array}{c}0.701 \pm 0.033 \\
(-2 \%)\end{array}$ & $\begin{array}{c}0.777 \pm 0.020 \\
(+9 \%)^{(a)}\end{array}$ & $\begin{array}{c}0.876 \pm 0.063 \\
(+23 \%)^{(a)}\end{array}$ \\
\hline & $\begin{array}{l}\text { Relative liver } \\
\text { weight }\end{array}$ & $2.958 \pm 0.143$ & $\begin{array}{c}3.013 \pm 0.163 \\
(+2 \%)\end{array}$ & $\begin{array}{c}3.200 \pm 0.180 \\
(+8 \%)^{(a)}\end{array}$ & $\begin{array}{c}3.600 \pm 0.272 \\
(+22 \%)^{(a)}\end{array}$ \\
\hline \multirow[t]{3}{*}{ Females } & $\begin{array}{l}\text { Terminal body } \\
\text { weight }(\mathrm{g})\end{array}$ & $232.29 \pm 8.10$ & $\begin{array}{c}234.43 \pm 23.28 \\
(+1 \%)\end{array}$ & $\begin{array}{c}219.51 \pm 9.92 \\
(-6 \%)\end{array}$ & $\begin{array}{c}216.19 \pm 14.75 \\
(-7 \%)\end{array}$ \\
\hline & $\begin{array}{l}\text { Relative kidney } \\
\text { weight }\end{array}$ & $0.676 \pm 0.053$ & $\begin{array}{c}0.645 \pm 0.060 \\
(-5 \%)\end{array}$ & $0.678 \pm 0.058(-)$ & $\begin{array}{c}0.822 \pm 0.044 \\
(+22 \%)^{(a)}\end{array}$ \\
\hline & $\begin{array}{l}\text { Relative liver } \\
\text { weight }\end{array}$ & $2.902 \pm 0.191$ & $\begin{array}{c}3.003 \pm 0.327 \\
(+3 \%)\end{array}$ & $\begin{array}{c}3.295 \pm 0.181 \\
(+14 \%)^{(a)}\end{array}$ & $\begin{array}{c}4.046 \pm 0.174 \\
(+39 \%)^{(a)}\end{array}$ \\
\hline \multicolumn{6}{|c|}{ Marinescu et al. (2020) } \\
\hline \multicolumn{2}{|c|}{ Dose (mg/kg bw per day) } & 0 & 300 & 500 & 1,200 \\
\hline Males & $\begin{array}{l}\text { Terminal body } \\
\text { weight }(g)\end{array}$ & $534.3 \pm 72.4$ & $\begin{array}{c}518.6 \pm 39.2 \\
(-3 \%)\end{array}$ & $\begin{array}{c}506.1 \pm 39.4 \\
(-5 \%)\end{array}$ & $\begin{array}{c}463.6 \pm 40.3 \\
(-13 \%)^{(a)}\end{array}$ \\
\hline Females & $\begin{array}{l}\text { Terminal body } \\
\text { weight }(\mathrm{g})\end{array}$ & $288.3 \pm 28.8$ & $\begin{array}{c}274.9 \pm 29.5 \\
(-5 \%)\end{array}$ & $\begin{array}{c}270.5 \pm 29.1 \\
(-6 \%)\end{array}$ & $\begin{array}{c}275.4 \pm 35.7 \\
(-4 \%)\end{array}$ \\
\hline
\end{tabular}

(a): Statistically significant change compared to control group.

The applicant conducted a benchmark dose (BMD) modelling based on combined data from the two above-described 90-day subchronic toxicity studies (Conze et al., 2016; Marinescu et al., 2020), using male body weight as an endpoint. The Panel notes the difference in body weights of the rats involved (i.e. $119-135 \mathrm{~g}$ vs. $222-293 \mathrm{~g}$ at study start for the respective studies), in spite of the fact that rats of the same strain (Sprague Dawley) and age (i.e. 6-8 weeks at study start) were used. Because of such heterogeneity, the Panel considers that the two data sets cannot be combined and modelled together, and that the BMD modelling provided by the applicant cannot be used to identify a reference point for establishing a safe level of intake for the NF.

EFSA carried out BMD analyses of terminal body weight for the two studies separately, following the EFSA Guidance on the use of the benchmark dose approach in risk assessment (EFSA Scientific Committee, 2017). Upon visual evaluation of the consistency of the trends observed in both sexes in the respective studies (Table 5), the Panel decided to model the data for males and females combined for the study by Conze et al. (2016), and to model the data for males only for the study by Marinescu et al. (2020). In the latter, there was no indication of a dose-dependent effect in female rats on this endpoint.

The modelling was also applied to the changes in kidney-to-body weight and liver-to-body weight observed in male and female rats in the study by Conze et al. (2016). These data sets were selected based on the dose-dependent effects observed on these endpoints in both sexes (Table 5). Because of the inaccuracies in the values for relative organ weights reported in the study by Marinescu et al. (2020), they could not be used for BMD modelling. 
A benchmark response (BMR) of 5\% was used for all endpoints and model averaging was applied. Results are reported in Table 6 and Appendix D.

Table 6: Results of BMD modelling on body weight, relative liver weight and relative kidney weight

\begin{tabular}{l|l|c|c|c}
\hline \multirow{2}{*}{ Reference } & Sex & \multicolumn{2}{c}{ Body weight } & \multicolumn{2}{c}{ Relative liver weight Relative kidney weight } \\
\cline { 2 - 5 } & & BMDL $_{\mathbf{0 5}}-\mathbf{B M D U}_{\mathbf{0 5}}$ & BMDL $_{\mathbf{0 5}}-\mathbf{B M D U}_{\mathbf{0 5}}$ & BMDL $_{\mathbf{0 5}}-\mathbf{B M D U}_{\mathbf{0 5}}$ \\
\hline Conze et al. (2016) & $\begin{array}{l}\text { Males and } \\
\text { females }\end{array}$ & $55-563$ & $226-721$ & $425-1040$ \\
\hline Marinescu et al. (2020) & Males $^{(\mathrm{a})}$ & $104-1110$ & - & - \\
\hline
\end{tabular}

$\mathrm{BMDL}_{05}$ : benchmark dose $95 \%$ one-sided lower confidence limit using a benchmark response of $5 \%$; $\mathrm{BMDU}_{05}$ : benchmark dose $95 \%$ one-sided upper confidence limit using a benchmark response of $5 \%$.

(a): There is no dose-dependent effect on body weight in female rats in the study.

The $95 \%$ one-sided lower confidence limits of the benchmark dose $\left(\mathrm{BMDL}_{05}\right)$ for body weight were 55 and $104 \mathrm{mg} / \mathrm{kg}$ bw per day based on the study by Conze et al. (2016) and Marinescu et al. (2020), respectively. The $B M D L_{05}$ for relative liver weight and relative kidney weight were 226 and $425 \mathrm{mg} / \mathrm{kg}$ bw per day, respectively, based on the study by Conze et al. (2016).

The Panel notes that BMD modelling of terminal body weight provides the lowest $B M D L_{05}(55 \mathrm{mg} / \mathrm{kg} \mathrm{bw}$ based on the data from the study by Conze et al.), but results in wide confidence intervals (BMDU/BMDL ratios $>10$ ) for both studies, indicating high uncertainty. In addition, the central estimate of the BMD of $190 \mathrm{mg} / \mathrm{kg}$ bw per day based on the data set from Conze et al. is below the lowest dose of $300 \mathrm{mg} / \mathrm{kg} \mathrm{bw}$ per day tested in that study (Appendix D). Extrapolation below the lowest dose implies additional uncertainty.

The Panel also notes that, among the two other endpoints, the lowest $\mathrm{BMDL}_{05}$, which was obtained for relative liver weight based on Conze et al. (226 mg/kg bw per day), showed a narrower confidence interval (BMDU/BMDL ratio 3.2) compared to the endpoint bw.

\subsubsection{Reproductive and developmental toxicity}

No new data were submitted.

\subsubsection{Human data}

In its previous submission, the applicant provided one single dose pharmacokinetic study (Wilson, 2015; Trammell et al., 2016) and four clinical trials (Airhart et al., 2017; Martens, 2017; Dollerup et al., 2018; Martens et al., 2018; Schacter, 2018; Conze et al.,) in which safety-related parameters following the consumption of the NF were addressed. These studies were conducted with healthy, adult human subjects and doses of the NF from $100 \mathrm{mg}$ for 1 day up to $2,000 \mathrm{mg} /$ day for 12 weeks. The Panel noted that the changes in haematology and clinical chemistry reported in these studies remained within reference ranges and that no dose-dependent adverse effects in the safety parameter examined were observed (EFSA NDA Panel, 2019).

As part of the present evaluation, the applicant provided the results of a post hoc analysis of the study by Conze et al. (2019) and Schacter (2018) to determine if 8 weeks of NRC supplementation at doses of 100,300 and $1,000 \mathrm{mg} /$ day affected circulating levels of pro- and anti-inflammatory cytokines (IL6, INF $\gamma$, IL-1 $\beta$, IL-2, IL-4, IL-5, IL-8, IL-10, IL-12p70, IL-13, IL-18, TNF $\alpha$, hs-CRP). The trial involved 140 healthy men and women ( $n=30$ per dose group) aged 40-60 years and with BMI $25-30.1 \mathrm{~kg} / \mathrm{m}^{2}$. No significant changes were observed for any of the parameters.

Two additional human studies on NRC were provided by the applicant as part of the present evaluation (Maki et al., 2020; Remie et al., 2020). They are summarised in Table 7.

The applicant also provided a clinical trial on a combination of nicotinamide riboside and pterostilbene, a polyphenol found in blueberries (Dellinger et al., 2017). The Panel considers that the study cannot be used for the safety assessment of the NF as nicotinamide riboside was combined with another substance.

The Panel concludes that the available human studies on NRC do not raise safety concerns. 
Table 7: Overview of human studies provided as part of the present request for extension of uses

\begin{tabular}{|c|c|c|c|c|c|c|}
\hline Reference & Study design & $\begin{array}{l}\text { Study } \\
\text { population }\end{array}$ & $\begin{array}{l}\text { Duration of } \\
\text { study }\end{array}$ & Doses & $\begin{array}{l}\text { Safety-related } \\
\text { parameters } \\
\text { investigated }\end{array}$ & Summary of results \\
\hline $\begin{array}{l}\text { Maki et al. } \\
\text { (2020) }\end{array}$ & $\begin{array}{l}\text { Randomised, } \\
\text { double-blind, } \\
\text { placebo } \\
\text { controlled, } \\
\text { 3-period } \\
\text { crossover study }\end{array}$ & $\begin{array}{l}36 \text { healthy adults } \\
\text { (BMI of } 18.5- \\
34.99 \mathrm{~kg} / \mathrm{m}^{2} \text { ) and } \\
\text { score of } \geq 80 \text { on } \\
\text { the Executive } \\
\text { Function domain } \\
\text { of the Central } \\
\text { Nervous System } \\
\text { Vital Signs (CNS } \\
\text { VS) Test Battery } \\
\text { Age } \geq 55 \text { years }\end{array}$ & $\begin{array}{l}\text { Each subject } \\
\text { received each } \\
\text { of the two } \\
\text { treatment or } \\
\text { placebo twice } \\
\text { daily for } \\
8 \text { weeks } \\
\text { No washout } \\
\text { period was } \\
\text { included; } \\
\text { carryover not } \\
\text { expected. }\end{array}$ & $\begin{array}{l}300 \mathrm{mg} \\
\mathrm{NRC} \\
1,000 \mathrm{mg} \\
\text { NRC } \\
\text { Placebo } \\
\\
\end{array}$ & $\begin{array}{l}\text { Anthropometric } \\
\text { measures, } \\
\text { haematology and } \\
\text { clinical chemistry } \\
\text { (CBC, Na, K, Cl, } \\
\text { creatinine, BUN, } \\
\text { AST, ALT, ALP, } \\
\text { bilirubin, albumin, } \\
\text { globulin, total } \\
\text { protein, Ca, carbon } \\
\text { dioxide, glucose } \\
\text { and eGFR) } \\
\text { Resting BP and } \\
\text { heart rate } \\
\text { Monitoring of AEs }\end{array}$ & $\begin{array}{l}\text { AEs classified as possibly related to the treatment } \\
1,000 \mathrm{mg} \text { NRC group ( } 2 \text { AEs): Difficulty sleeping, } \\
\text { withdrawn) } \\
300 \mathrm{mg} \text { NRC group: none } \\
\text { Placebo group ( } 3 \mathrm{AEs} \text { ): Brittle nails, dry skin, elevated creatinine } \\
\text { (subject withdrawn) } \\
\text { Haematology and clinical chemistry } \\
\text { No significant between-group differences reported in haematology } \\
\text { values (including platelet count) or serum chemistry values, except for } \\
\text { a small difference for fasting serum glucose between } 300 \mathrm{mg} \text { and } \\
1,000 \text { mg NRC and placebo [median (IQL) values in mg/dL: placebo, } \\
91.5(82.0,102.5) ; 300 \text { mg/day NR, } 94.0(86.0,110.0) ; 1000 \mathrm{mg} / \mathrm{day} \\
\text { NR, } 93.0 \text { ( } 89.0,106.5)], \text { which reached statistical significance } \\
\text { between the placebo and high-dose group. } \\
\text { Median fasting glucose concentrations were lower at the end of } \\
\text { intervention than at baseline, in all groups and within the normal } \\
\text { clinical reference range. } \\
\text { Vital signs } \\
\text { No significant differences between treatments in heart rate, systolic } \\
\text { and diastolic BP. }\end{array}$ \\
\hline
\end{tabular}




\begin{tabular}{|c|c|c|c|c|c|c|}
\hline Reference & Study design & $\begin{array}{l}\text { Study } \\
\text { population }\end{array}$ & $\begin{array}{l}\text { Duration of } \\
\text { study }\end{array}$ & Doses & $\begin{array}{l}\text { Safety-related } \\
\text { parameters } \\
\text { investigated }\end{array}$ & Summary of results \\
\hline $\begin{array}{l}\text { Remie et al. } \\
(2020)\end{array}$ & $\begin{array}{l}\text { Randomised, } \\
\text { double-blind, } \\
\text { placebo- } \\
\text { controlled } \\
\text { crossover } \\
\text { intervention } \\
\text { study } \\
\text { The sample size } \\
\text { was determined } \\
\text { based on } \\
\text { demonstrating } \\
\text { the statistical } \\
\text { superiority of NR } \\
\text { on insulin- } \\
\text { stimulated } \\
\text { skeletal muscle } \\
\text { glucose disposal } \\
\text { compared with } \\
\text { placebo }\end{array}$ & $\begin{array}{l}13 \text { healthy } \\
\text { overweight or } \\
\text { obese participants } \\
\left.\text { (7o; } 6 \sigma^{\prime}\right) \\
\text { Age: } 59 \pm 5 \text { years } \\
\text { BMI: } \\
30.2 \pm 2.6 \mathrm{~kg} / \mathrm{m}^{2}\end{array}$ & $\begin{array}{l}6 \text { weeks } \rightarrow \\
4-7 \text { weeks } \\
\text { washout } \\
\text { period } \rightarrow \\
6 \text { weeks of } \\
\text { other } \\
\text { treatment }\end{array}$ & $\begin{array}{l}\text { Placebo or } \\
1,000 \mathrm{mg} / \\
\text { day NRC }\end{array}$ & $\begin{array}{l}\text { Insulin sensitivity } \\
\text { via } \\
\text { hyperinsulinaemic- } \\
\text { euglycaemic clamp; } \\
\text { intrahepatic and } \\
\text { intramuscular lipid } \\
\text { content by MRS } \\
\text { PCr:ATP ratio by } \\
\text { P-MRS, left } \\
\text { ventricular ejection } \\
\text { fraction, ambulatory } \\
\text { BP } \\
\text { Plasma } \\
\text { concentrations of } \\
\text { glucose, FFAs, TG, } \\
\text { cholesterol, HDL, } \\
\text { inflammatory } \\
\text { cytokine } \\
\text { concentrations } \\
\text { ( } \mathrm{n}=7 \text { participants) } \\
\text { Monitoring of AEs }\end{array}$ & $\begin{array}{l}\text { No AEs or side effects reported. } \\
\text { No effects on insulin sensitivity, hepatic and intramyocellular lipid } \\
\text { content, measures of cardiac function, plasma markers of } \\
\text { inflammation, glucose or lipids }\end{array}$ \\
\hline
\end{tabular}

AE: adverse event; ALP: alkaline phosphatase; ALT: alanine transaminase; AST: aspartate transaminase; BP: blood pressure; BMI: body mass index; BUN: blood urea nitrogen; Ca: calcium; CBC: complete blood count; Cl: chloride; eGFR: estimated glomerular filtration rate; FFAs: free fatty acids; HDL: high density lipoprotein; K: potassium; P-MRS: proton magnetic resonance spectroscopy; Na: sodium; NR: nicotinamide riboside chloride; PCr:ATP ratio: creatine phosphate:adenosine triphosphate ratio; RBC: red blood cell; TG: triglycerides; WBC: white blood cell. 


\subsubsection{Additional data}

EFSA commissioned a literature search (LS) from the University of Chemistry and Technology of Prague (Dibusz and Vejvodova, 2020), with the aim of identifying studies investigating the effect of nicotinamide riboside chloride intake on health outcomes in vivo with a focus on hepatic function, haematology parameters, methyl balance and carcinogenicity. These outcomes were prioritised considering the animal toxicity data available on NRC (Section 3.7) and potential adverse effects of high-dose nicotinamide and its precursors discussed in the literature (Knip et al., 2000; Poljsak, 2016; Sun et al., 2017; Zhang et al., 2018; Demarest et al., 2019; Braidy and Liu, 2020; Hwang and Song, 2020).

In view of the metabolism of nicotinamide riboside chloride (Section 3.5), data on nicotinamide and 1-methyl nicotinamide were considered relevant for the risk assessment of nicotinamide riboside chloride. Thus, these compounds were also covered by the search.

Appendix B presents the details of the search strategy, number of hits, workflow and outcome of the LS. Several papers discussed the potential adverse effects of high intake of nicotinamide or its precursors in the light of current knowledge of nicotinamide metabolism. Several routes have been proposed by which high intake of nicotinamide could lead to adverse health effects, including: (i) through affecting methyl group transfers in a variety of metabolic pathways and epigenetic mechanisms; (ii) through modulating $\mathrm{NAD}^{+}$metabolism; (iii) through an elevated circulation and renal excretion of nicotinamide metabolites, 1-methyl nicotinamide, 2-PYR (1-methyl-2-pyridone-5carboxamide), 4-PYR (1-methyl-4-pyridone-5-carboxamide) and the potential toxicity of these compounds. Mechanistic studies and related reviews on these topics are not described here.

No relevant additional data were retrieved through the LS in relation to potential adverse effects of nicotinamide or its precursors on hepatic function.

Cases of thrombocytopaenia have been reported in clinical trials in which supplemental doses of NAM were given to haemodialysis patients as a treatment for hyperphosphataemia. In a systematic review conducted by Zhang et al. (2018), seven randomised controlled trials on nicotinamide supplementation in haemodialysis patients were included (doses ranged between 400 and $1,500 \mathrm{mg}$ NAM/day, for 8-24 weeks). A higher risk of thrombocytopaenia was reported in the supplemented groups compared to placebo (15 cases in the NAM groups, receiving $500 \mathrm{mg}$ NAM/day or more, vs. five cases in the placebo groups) (Zhang et al., 2018). No serious adverse reactions were observed. The Panel notes that cases of thrombocytopenia were observed in patients undergoing haemodialysis treatment upon nicotinamide supplementation at doses of $500 \mathrm{mg} /$ day and above. In an 8-day openlabelled pharmacokinetics study in which increasing doses of NRC were administered orally to eight healthy adults (from $250 \mathrm{mg}$ on days 1 and 2 to $2,000 \mathrm{mg}$ on days 7 and 8), a slight decrease in mean platelet count was observed $(220,000 / \mu \mathrm{L}$ on day $1 \mathrm{vs}$. $200,000 / \mu \mathrm{L}$ on day $9, \mathrm{p}=0.031$ ) (Airhart et al., 2017). No effect on platelet counts was observed in the four placebo-controlled supplementation trials available on the NF (dose range: $100-1,000 \mathrm{mg} /$ day NRC) (Martens, 2017; Dollerup et al., 2018; Martens et al., 2018; Schacter, 2018; Conze et al., 2019; EFSA NDA Panel, 2019; Maki et al., 2020).

As discussed in the previous assessment, experimental studies in animal models (Kazgan et al., 2014; Tian et al., 2014) and acute loading studies in humans (Sun et al., 2012; Tian et al., 2013; Sun et al., 2017) suggest that high NAM intake, that undergoes methylation-mediated degradation, could affect the methyl group pool balance. The Panel considered, in 2019, that no conclusions could be drawn on potential adverse effects from the data available (EFSA NDA Panel, 2019). No relevant additional data were retrieved through the LS.

The LS did not retrieve human epidemiological studies on the association between NAM intake and risk of cancer. A role of nicotinamide in carcinogenicity has been subject of numerous experiments in animals.

In one mouse carcinogenicity study, NAM was found not to be carcinogenic when administered to mice as $1 \%$ NAM solution ( $900 \mathrm{mg} / \mathrm{kg} \mathrm{bw}^{23}$ ) in drinking water (corresponding to an average daily intake of $66.3 \mathrm{mg} /$ day in female mice and $100.5 \mathrm{mg} /$ day in male mice), during their lifespan (Toth, 1983).

An overview of animal experiments investigating the effect of NAM on chemical- and UVR-induced tumours is provided in Appendix C. Three experiments reported a promoting effect of NAM

\footnotetext{
${ }^{23}$ Applying a conversion factor of 0.09 to calculate doses in $\mathrm{mg} / \mathrm{kg}$ bw per day from concentrations in drinking water in $\mathrm{mg} / \mathrm{L}$, for chronic studies in mice (EFSA Scientific Committee, 2012. Guidance on selected default values to be used by the EFSA Scientific Committee, Scientific Panels and Units in the absence of actual measured data. EFSA Journal 2012;10(3):2579, 32 pp. https://doi.org/10.2903/j.efsa.2012.2579).
} 
administration on chemical-induced tumours (Rakieten et al., 1971; Schoental, 1977; Rosenberg et al., 1985). NAM was administered intraperitoneally in two of these studies and orally in one. NAM doses of $0.082 \%\left(41 \mathrm{mg} / \mathrm{kg} \mathrm{bw}^{24}\right)$ and $0.37 \%(183 \mathrm{mg} / \mathrm{kg} \mathrm{bw})$ administered in drinking water to rats for 20 months increased the incidence of diethylnitrosamine (DEN)-induced kidney tumours to $28 \%$ and $59 \%$, respectively, compared to $5 \%$ in controls (DEN only). NAM by itself had no effect on tumour formation (Rosenberg et al., 1985). High doses of nicotinamide $(350-500 \mathrm{mg} / \mathrm{kg}$ bw intraperitoneal, multiple dosing) inhibited DEN-induced liver tumours (34\% reduction), but promoted DEN-induced kidney neoplasia (44\% increase) in Wistar rats (Schoental, 1977). Intraperitoneal NAM $(350 \mathrm{mg} / \mathrm{kg}$ ) increased the incidence of streptozotocin-induced pancreatic islet cell tumours in F344 rats from $4 \%$ in controls (streptozotocin only) to 64\% (Rakieten et al., 1971), but it decreased the incidence of renal adenomas from $77 \%$ to $18 \%$ (Rakieten et al., 1976).

In CBA mice inoculated with an immunogenic mouse sarcoma line (adenotype 12 virus, A12B3) or the sarcoma $\mathrm{F}$ line, NAM between 100 and $1,000 \mathrm{mg} / \mathrm{kg}$ bw administered i.p. caused a high level of in vivo DNA strand breaks in tumours and normal tissues in mice bearing the immunogenic sarcoma, but not in the non-immunogenic sarcoma $\mathrm{F}$ line. The DNA repair process was delayed in association with an accumulation of NAM and NAD. No effect was observed at a dose of $10 \mathrm{mg} / \mathrm{kg}$ bw (Olsson et al., 1996).

One study was retrieved regarding the NAD+ precursor nicotinamide mononucleotide (NMN). In a pancreatic cancer mouse model, daily intraperitoneal injections of $500 \mathrm{mg} / \mathrm{kg}$ bw NMN administered to mice developing pancreatic intraepithelial neoplasia significantly decreased the proportion of normal acinar area in pancreas compared to controls, indicative of an increase in the amount of precancerous and cancerous lesions. This was accompanied by an increase in the amount of desmoplastic tissue in pancreas compared to controls (Nacarelli et al., 2019).

Overall, while the majority of animal studies report no or even protective effects of the administration of NAM or other $\mathrm{NAD}^{+}$precursors on cancer, some studies indicate that nicotinamide administration influences carcinogenesis in a dose-dependent and organ-specific manner, specifically in the presence of carcinogens and/or premalignant conditions.

The Panel notes that these studies were primarily designed to investigate the mechanisms of nicotinamide involved in various physiological and pathophysiological conditions and not to derive safe levels of intake with regard to potential risks for detrimental metabolic and epigenetic changes or tumour promotion. The Panel notes a lack of studies addressing these concerns. In particular, with regard to vulnerable population groups such as children, pregnant and lactating women and individuals with premalignant conditions, the available studies do not provide sufficient evidence to conclude on a safe high level of intake.

\subsection{Allergenicity}

The NF is a synthetic product containing $>90 \%$ nicotinamide riboside chloride. Potential process impurities have been well characterised. Since the NF does not contain any protein, the risk of allergenicity is low (EFSA NDA Panel, 2019).

\section{Discussion}

The evaluation addresses a request for an extension of use of nicotinamide riboside chloride. The NDA Panel previously concluded that nicotinamide riboside chloride is safe to be used in food supplements for the healthy adult population at doses up to $300 \mathrm{mg} /$ day and for pregnant and lactating women at doses up to $230 \mathrm{mg} /$ day (EFSA NDA Panel, 2019). The Panel confirmed the bioavailability of nicotinamide, a form of niacin, from that source. The Panel also noted the similar toxicity profiles of nicotinamide riboside chloride and nicotinamide demonstrated in a toxicity study in rats.

The applicant requests to use the NF in 'meal replacement products' and 'nutritional drink mixes' at a maximum use level of $300 \mathrm{mg}$ of NRC per day, which corresponds to an intake of $126 \mathrm{mg}$ nicotinamide per day. The applicant requested to exclude infants, children, pregnant or lactating women from the target population for the consumption of 'meal replacement products' and 'nutritional

\footnotetext{
${ }^{24}$ Applying a conversion factor of 0.05 to calculate doses in $\mathrm{mg} / \mathrm{kg}$ bw per day from concentrations in drinking water in $\mathrm{mg} / \mathrm{L}$, for chronic studies in rats (EFSA Scientific Committee, 2012. Guidance on selected default values to be used by the EFSA Scientific Committee, Scientific Panels and Units in the absence of actual measured data. EFSA Journal 2012;10(3):2579, 32 pp. https://doi.org/10.2903/j.efsa.2012.2579).
} 
drink mixes', but the Panel notes that such consumption cannot be excluded for these population groups. The applicant also requests to use the NF in foods for special medical purposes (FSMP) and total diet replacements products for weight control (TDRWC) at a maximum use level of $500 \mathrm{mg}$ of NRC per day (i.e. $7.1 \mathrm{mg} / \mathrm{kg}$ bw in a 70-kg adult), which corresponds to an intake of $210 \mathrm{mg}$ nicotinamide per day. The target population for these products are adults only, excluding pregnant and lactating women.

The Panel notes that the proposed use levels greatly exceed the physiological requirement for niacin for all population groups.

In the previous evaluation, an NOAEL of $300 \mathrm{mg} / \mathrm{kg}$ bw per day was identified from the available repeated dose toxicity studies with rats and dogs conducted with the NF. An NOAEL for maternal and embryo/fetotoxicity of $325 \mathrm{mg} / \mathrm{kg}$ bw per day was identified from an embryo-fetal developmental toxicity study on the NF.

One additional 90-day toxicity study in rats was provided (Marinescu et al., 2020) as part of the present application. The study was conducted with NRC produced by another company, which the Panel considers representative of the NF. The findings reported in this new study were similar to the findings in the 90-day toxicity study conducted with the NF (Bhoite et al., 2015; Conze et al., 2016).

The Panel applied BMD analyses to terminal body weight, relative kidney weight and relative liver weight of the study by Conze et al. (2016), where dose-dependent effects in male and female rats were observed. The Panel also applied a BMD analysis to terminal body weight of the study by Marinescu et al. (2020), where a dose-dependent effect in male rats was observed. The most sensitive adverse effect was a decrease in body weight, providing a $\mathrm{BMDL}_{05}$ of $55 \mathrm{mg} / \mathrm{kg}$ bw, based on the data from the study by Conze et al. (2016). The Panel noted the high modelling uncertainty for this endpoint, and that the modelling uncertainty was lower for the increase in relative liver weight, providing a $\mathrm{BMDL}_{05}$ of $226 \mathrm{mg} / \mathrm{kg}$ bw per day.

Regarding the request for extension of use in 'meal replacement products' and 'nutritional drink mixes', the Panel notes the lack of an UL for nicotinamide in infants. The Panel also notes that the MoE between the estimated intake of $60 \mathrm{mg} \mathrm{NRC} / \mathrm{kg}$ bw per day in infants and the BMDL 05 of 55 and $226 \mathrm{mg} / \mathrm{kg}$ bw per day estimated for the selected endpoints in the animal toxicity studies would be $<4$. In the absence of data that could be used to establish a safe level of intake of NRC in infants, the Panel considers that the safety of use of the NF in 'meal replacement products' and 'nutritional drink mixes' under the proposed conditions of uses is not established.

Regarding the request for extension of use in FSMP and TDRWC, the Panel notes the proposed maximum use level of $500 \mathrm{mg}$ of NRC per day $(7.1 \mathrm{mg} / \mathrm{kg} \mathrm{bw})$, corresponding to an intake of $210 \mathrm{mg}$ nicotinamide per day, which is below the current UL for nicotinamide of $900 \mathrm{mg} /$ day for adults. The Panel considers that, in the context of this UL, the NF can be considered as safe as pure nicotinamide, which is authorised for use in FSMP and TDRWC (Annex of Regulation (EC) No 609/2013 ${ }^{25}$ ). The Panel notes that the MoE between the estimated intake, based on the proposed maximum use level, and the $\mathrm{BMDL}_{05}$ of 55 and $226 \mathrm{mg} / \mathrm{kg}$ bw per day estimated for the selected endpoints in the animal toxicity studies are 8 and 32 , respectively.

The Panel also notes that the scientific evidence on the toxicity of nicotinamide has increased since the SCF established the UL. Experimental data indicate several pathways by which intakes of nicotinamide that are substantially higher than the physiological requirement, or its precursors, might cause adverse effects. The Panel considers that further investigations are required to elucidate the effects of nicotinamide, or its precursors, at doses which are substantially higher than the physiological requirement for niacin, the results of which may necessitate a re-evaluation of the UL for nicotinamide.

\section{Conclusions}

The Panel concludes that the safety of the novel food, nicotinamide riboside chloride, has not been established for use in 'meal replacement products' and 'nutritional drink mixes'.

The Panel concludes that the NF, nicotinamide riboside chloride, is as safe as pure nicotinamide, for use in FSMP and TDRWC (Annex of Regulation (EC) No 609/201325). The maximum use level of $500 \mathrm{mg}$ of NRC per day corresponds to a maximum intake of $210 \mathrm{mg}$ nicotinamide per day.

\footnotetext{
${ }^{25}$ Regulation (EU) No 609/2013 of the European Parliament and of the Council of 12 June 2013 on food intended for infants and young children, food for special medical purposes, and total diet replacement for weight control and repealing Council Directive 92/52/EEC, Commission Directives 96/8/EC, 1999/21/EC, 2006/125/EC and 2006/141/EC, Directive 2009/39/EC of the European Parliament and of the Council and Commission Regulations (EC) No 41/2009 and (EC) No 953/2009. OJ L 181, 29.6.2013, p. 35-56.
} 


\subsection{Protection of Proprietary data in accordance with Article 26 of Regulation (EU) 2015/2283}

The Panel could not have reached the conclusion on the safety of the NF under the proposed conditions of use without the following data claimed as proprietary by the applicant: an in vitro study evaluating the metabolism of nicotinamide riboside in blood (Study No. 160312); an oral 7-day dose range finding toxicity study in juvenile dogs (study No. SN17-921); a 28-day repeated-dose oral toxicity study in juvenile dogs (Study No. SN17-940); a 90-day repeated-dose oral toxicity study in Sprague-Dawley rats (Study No. S14022); a reproductive toxicity study (Study No. G10959) and a developmental toxicity study (Study No. G10957) in rats.

\section{Steps taken by EFSA}

1) On 8 June 2020, EFSA received a letter from the European Commission with the request for a scientific opinion on the extension of use of nicotinamide riboside chloride as NF (Ref. Ares (2020)2952737).

2) On 8 June 2020, a valid application on the extension of use of nicotinamide riboside chloride as NF, which was submitted by ChromaDex Inc., was made available to EFSA by the European Commission through the Commission e-submission portal (NF 2020/1613) and the scientific evaluation procedure was initiated.

3) On 23 October 2020, EFSA requested the applicant to provide additional information to accompany the application and the scientific evaluation was suspended.

4) On 22 December 2020, additional information was provided by the applicant through the Commission e-submission portal and the scientific evaluation was restarted.

5) On 18 January 2021, EFSA requested the applicant to provide further clarifications to the additional information provided.

6) On 09 February 2021, additional clarifications were provided by the applicant through the Commission e-submission portal and the scientific evaluation was restarted.

7) On 12 February 2021, EFSA requested the applicant to provide additional information to accompany the application and the scientific evaluation was suspended.

8) On 13 March 2021, additional information was provided by the applicant through the Commission e-submission portal and the scientific evaluation was restarted.

9) During its meeting on 14 September 2021, the NDA Panel, having evaluated the data, adopted a scientific opinion on the safety of the extension of use of nicotinamide riboside chloride as a NF pursuant to Regulation (EU) 2015/2283.

\section{References}

Airhart SE, Shireman LM, Risler LJ, Anderson GD, Nagana Gowda GA, Raftery D, Tian R, Shen DD and O'Brien KD, 2017. An open-label, non-randomized study of the pharmacokinetics of the nutritional supplement nicotinamide riboside (NR) and its effects on blood NAD ${ }^{+}$levels in healthy volunteers. PLoS One, 12, e0186459. https://doi. org/10.1371/journal.pone.0186459

Al-Gayyar MMH, Bagalagel A, Noor AO, Almasri DM and Diri R, 2019. The therapeutic effects of nicotinamide in hepatocellular carcinoma through blocking IGF-1 and effecting the balance between Nrf2 and PKB. Biomedicine \& Pharmacotherapy, 112. https://doi.org/10.1016/j.biopha.2019.108653

Bartleman AP, Jacobs R and Kirkland JB, 2008. Niacin supplementation decreases the incidence of alkylationinduced nonlymphocytic leukemia in Long-Evans rats. Nutrition and Cancer, 60, 251-258. https://doi.org/10. 1080/01635580701649628

Bhoite P and Jayachandra K (Syngene International Limited), 2014. Single Dose Oral Toxicity Study of Niagen in Sprague Dawley Rats. Bangalore, India. $60 \mathrm{pp}$.

Bhoite P, Jayachandra K and Suman M (Syngene International Limited), 2015. Comparative 90-Day Oral Toxicity Study of Niagen and Nicotinamide in Sprague Dawley Rats. Bangalore, India. $291 \mathrm{pp}$.

Braidy $\mathrm{N}$ and Liu $\mathrm{Y}$, 2020. Can nicotinamide riboside protect against cognitive impairment? Current Opinion in Clinical Nutrition and Metabolic Care, 23, 413-420. https://doi.org/10.1097/MCO.0000000000000691

Conze DB, Crespo-Barreto J and Kruger CL, 2016. Safety assessment of nicotinamide riboside, a form of vitamin B3. Human and Experimental Toxicology, 35, 1149-1160. https://doi.org/10.1177/0960327115626254

Conze D, Brenner C and Kruger CL, 2019. Safety and metabolism of long-term administration of NIAGEN (nicotinamide riboside chloride) in a randomized, double-blind, placebo-controlled clinical trial of healthy overweight adults. Scientific Reports, 9, 9772. https://doi.org/10.1038/s41598-019-46120-z 
Dellinger RW, Santos SR, Morris M, Evans M, Alminana D, Guarente L and Marcotulli E, 2017. Repeat dose NRPT (nicotinamide riboside and pterostilbene) increases $\mathrm{NAD}(+)$ levels in humans safely and sustainably: a randomized, double-blind, placebo-controlled study. NPJ Aging and Mechanisms of Disease, 3, 17. https://doi. org/10.1038/s41514-017-0016-9

Demarest TG, Babbar M, Okur MN, Dan X, Croteau DL, Fakouri NB, Mattson MP and Bohr VA, 2019. NAD metabolism in aging and cancer. Annual Review of Cancer Biology, 3, 105-130. https://doi.org/10.1146/ annurev-cancerbio-030518-055905

Dibusz $\mathrm{K}$ and Vejvodova $\mathrm{P}, 2020$. Systematic literature search to assist EFSA in the preparatory work for the safety assessment of Novel Food applications and Traditional Food notifications. EFSA Supporting Publications, 17, 1774E. https://doi.org/10.2903/sp.efsa.2019.EN-1774

Dollerup OL, Christensen B, Svart M, Schmidt MS, Sulek K, Ringgaard S, Stodkilde-Jorgensen H, Moller N, Brenner C, Treebak JT and Jessen N, 2018. A randomized placebo-controlled clinical trial of nicotinamide riboside in obese men: safety, insulin-sensitivity, and lipid-mobilizing effects. American Journal of Clinical Nutrition, 108, 343-353. https://doi.org/10.1093/ajcn/nqy132

EFSA (European Food Safety Authority), 2004. Opinion of the Scientific Panel on food additives, flavourings, processing aids and materials in contact with food (AFC) on a request from the Commission related to Furfural and Furfural Diethylacetal. EFSA Journal 2004;2:67, 26 pp. https://10.2903/j.efsa.2004.67

EFSA (European Food Safety Authority), 2006. Opinion of the Scientific Committee on Food on the tolerable upper intake level of nicotinic acid and nicotinamide (Niacin): expressed on 17 April 2002. In: SCF (Scientific Committee on Food) and EFSA NDA Panel (Scientific Panel on Dietetic Products, Nutrition and Allergies). Tolerable upper intake levels for vitamins and minerals. EFSA, s.I. 121-134. pp. Available online: https://www. efsa.europa.eu/sites/default/files/efsa_rep/blobserver_assets/ndatolerableuil.pdf

EFSA ANS Panel (EFSA Panel on Food Additives and Nutrient Sources added to Food), Younes M, Aggett $P$, Aguilar F, Crebelli R, Dusemund B, Filipicč M, Frutos MJ, Galtier P, Gundert-Remy U, Kuhnle GG, Lambré C, Leblanc J-C, Lillegaard IT, Moldeus P, Mortensen A, Oskarsson A, Stankovic I, Waalkens-Berendsen I, Woutersen RA, Wright M, Di Domenico A, Fairweather-Tait S, McArdle H, Smeraldi C and Gott D, 2018. Guidance on safety evaluation of sources of nutrients and bioavailability of nutrient from the sources. EFSA Journal 2018;16:5294. https://doi. org/10.2903/j.efsa.2018.5294

EFSA NDA Panel (EFSA Panel on Dietetic Products, Nutrition and Allergies), 2014. Scientific opinion on dietary reference values for niacin. EFSA Journal 2014;12(7):3759, 42 pp. https://10.2903/j.efsa.2014.3759

EFSA NDA Panel, (EFSA Panel on Dietetic Products, Nutrition and Allergies), Turck D, Bresson J-L, Burlingame B, Dean T, Fairweather-Tait S, Heinonen $M$, Hirsch-Ernst KI, Mangelsdorf I, McArdle $H$, Naska A, NeuhäuserBerthold M, Nowicka G, Pentieva K, Sanz Y, Siani A, Sjödin A, Stern M, Tomé D, Vinceti M, Willatts P, Engel K$H$, Marchelli R, Pöting A, Poulsen M, Salminen S, Schlatter J, Arcella D, Gelbmann W, de Sesmaisons-Lecarré A, Verhagen $\mathrm{H}$ and van Loveren $\mathrm{H}, 2016$. Guidance on the preparation and presentation of an application for authorisation of a novel food in the context of Regulation (EU) 2015/2283. EFSA Journal 2016;14(11):e04594, 24 pp. https://doi.org/10.2903/j.efsa.2016.4594

EFSA NDA Panel (EFSA Panel on Dietetic Products, Nutrition and Allergies), Turck D, Bresson J-L, Burlingame B, Dean T, Fairweather-Tait S, Heinonen $M$, Hirsch-Ernst $K$, Mangelsdorf I, McArdle $H$, Naska A, NeuhäuserBerthold M, Nowicka G, Pentieva K, Sanz Y, Siani A, Sjödin A, Stern M, Tomé D, Vinceti M, Willatts P, Engel K$H$, Marchelli R, Pöting A, Poulsen M, Schlatter J, Germini A and Van Loveren $H, 2018$. Scientific opinion on safety of d-ribose as a novel food pursuant to Regulation (EU) 2015/2283. EFSA Journal 2018;16(5):5265, 75 pp. https://doi.org/10.2903/j.efsa.2018.5265

EFSA NDA Panel (EFSA Panel on Dietetic Products, Nutrition and Allergies), Turck D, Castenmiller J, de Henauw $S$, Hirsch-Ernst KI, Kearney J, Maciuk A, Mangelsdorf I, McArdle HJ, Naska A, Pelaez C, Pentieva K, Siani A, Thies F, Tsabouri S, Vinceti M, Cubadda F, Engel KH, Frenzel T, Heinonen M, Marchelli R, Neuhauser-Berthold M, Poting A, Poulsen M, Sanz Y, Schlatter JR, van Loveren Agnes de Sesmaisons-Lecarre H, Germini A and Knutsen HK, 2019. Safety of nicotinamide riboside chloride as a novel food pursuant to Regulation (EU) 2015/ 2283 and bioavailability of nicotinamide from this source, in the context of Directive 2002/46/EC. EFSA Journal 2019;17(8):e05775, 45 pp. https://doi.org/10.2903/j.efsa.2019.5775

EFSA Scientific Committee, 2012. Guidance on selected default values to be used by the EFSA Scientific Committee, Scientific Panels and Units in the absence of actual measured data. EFSA Journal 2012;10(3):2579, 32 pp. https://doi.org/10.2903/j.efsa.2012.2579

EFSA Scientific Committee, Hardy A, Benford D, Halldorsson T, Jeger MJ, Knutsen KH, More S, Mortensen A, Naegeli H, Noteborn H, Ockleford C, Ricci A, Rychen G, Silano V, Solecki R, Turck D, Aerts M, Bodin L, Davis A, Edler L, Gundert-Remy U, Sand S, Slob W, Bottex B, Abrahantes JC, Marques DC, Kass G and Schlatter JR, 2017. Update: guidance on the use of the benchmark dose approach in risk assessment. EFSA Journal 2017;15 (1):4658, 41 pp. https://doi.org/10.2903/j.efsa.2017.4658

French FA, 1977. The influence of nutritional factors on pulmonary adenomas in mice. Advances in Experimental Medicine and Biology, 91, 281-292. https://doi.org/10.1007/978-1-4684-0796-9_19

Ganiger S (Advinus Therapeutics Limited), 2016. Nicotinamide Riboside Chloride: One Generation Reproduction Toxicity Study Through Diet in Sprague-Dawley Rats. Bangalore, India. 313 pp. 
Geetha Rao G (Advinus Therapeutics Limited), 2016. Nicotinamide Riboside Chloride: Embryo-Fetal Developmental Toxicity Study in Sprague Dawley Rats by Oral Route. Bangalore, India. 319 pp.

Gensler HL, 1997. Prevention of photoimmunosuppression and photocarcinogenesis by topical nicotinamide. Nutrition and Cancer, 29, 157-162. https://doi.org/10.1080/01635589709514618

Gensler HL, Williams T, Huang AC and Jacobson EL, 1999. Oral niacin prevents photocarcinogenesis and photoimmunosuppression in mice. Nutrition and Cancer, 34, 36-41. https://doi.org/10.1207/ S15327914NC340105

Gotoh H, Nomura T, Nakajima $H$, Hasegawa $C$ and Sakamoto $Y, 1988$. Inhibiting effects of nicotinamide on urethane-induced malformations and tumors in mice. Mutation Research, 199, 55-63. https://doi.org/10.1016/ 0027-5107(88)90230-8

Gotoh H, Nomura T and Hasewaga C, 1993. Growth-inhibition of transplanted murine-breast cancer by nicotinamide in $\mathrm{C} 3 \mathrm{H} / \mathrm{HEJ}$ mice. Cancer Research Therapy \& Control, 3, 121-126.

Horsman MR, Khalil AA, Chaplin DJ and Overgaard J, 1995. The ability of nicotinamide to inhibit the growth of a C3H mouse mammary carcinoma. Acta Oncologica, 34, 443-446. https://doi.org/10.3109/02841869509094006

Hwang ES and Song SB, 2020. Possible adverse effects of high-dose nicotinamide: mechanisms and safety assessment. Biomolecules, 10, 687. https://doi.org/10.3390/biom10050687

Kamath G (Syngene International Limited), 2015. Bacterial Reverse Mutation Test with Niagen. Bangalore, India. 71 pp.

Kamath G (Syngene International Limited), 2016. In Vitro Mammalian Chromosome Aberration Test Using Human Peripheral Blood Lymphocyte with Niagen. Bangalore, India. 69 pp.

Kato T, Berger SJ, Carter JA and Lowry $\mathrm{OH}, 1973$. An enzymatic cycling method for nicotinamide-adenine dinucleotide with malic and alcohol dehydrogenases. Analytical Biochemistry, 53, 86-97. https://doi.org/10. 1016/0003-2697(73)90409-0

Kazgan N, Metukuri MR, Purushotham A, Lu J, Rao A, Lee S, Pratt-Hyatt M, Lickteig A, Csanaky IL, Zhao Y, Dawson PA and Li X, 2014. Intestine-specific deletion of SIRT1 in mice impairs DCoH2-HNF-1alpha-FXR signaling and alters systemic bile acid homeostasis. Gastroenterology, 146, 1006-1016. https://doi.org/10. 1053/j.gastro.2013.12.029

Kim SK, Yun SJ, Kim J, Lee OJ, Bae SC and Kim WJ, 2011a. Identification of gene expression signature modulated by nicotinamide in a mouse bladder cancer model. PLoS One, 6, e26131, https://doi.org/10.1371/journal.pone. 0026131

Kim WJ, Lee JW, Quan C, Youn HJ, Kim HM and Bae SC, 2011b. Nicotinamide inhibits growth of carcinogen induced mouse bladder tumor and human bladder tumor xenograft through up-regulation of RUNX3 and p300. Journal of Urology, 185, 2366-2375. https://doi.org/10.1016/j.juro.2011.02.017

Knip M, Douek IF, Moore WP, Gillmor HA, McLean AE, Bingley PJ and Gale EA; and European Nicotinamide Diabetes Intervention Trial G, 2000. Safety of high-dose nicotinamide: a review. Diabetologia, 43, 1337-1345. https://10.1007/s001250051536

Ludwig A, Dietel M, Schafer G, Muller K and Hilz H, 1990. Nicotinamide and nicotinamide analogues as antitumor promoters in mouse skin. Cancer Research, 50, 2470-2475.

Maki KC, Dicklin MR, Sanders LM, Palacios OM, Wilcox M, and Maki CE (MB Clinical Research), 2020. Safety and Metabolic Effects of Nicotinamide Riboside in a Randomized, Double-blind, Crossover, Placebo-controlled Trial of Men and Women $\geq 55$ Years of Age. Boca Raton, Florida, United States. Unpublished study report, 25 pp.

Marinescu AG, Chen J, Holmes HE, Guarente L, Mendes O, Morris M and Dellinger RW, 2020. Safety assessment of high-purity, synthetic nicotinamide riboside (NR-E) in a 90-day repeated dose oral toxicity study, with a 28-day recovery arm. International Journal of Toxicology, 39, 307-320. https://doi.org/10.1177/1091581820927406

Martens C (The Integrative Physiology of Aging Laboratory, University of Colorado Boulder), 2017. NIAGEN@ Supplementation for Improving Physical and Metabolic Function in Midlife and Older Adult Humans. Boulder, CO, USA, 28 pp.

Martens CR, Denman BA, Mazzo MR, Armstrong ML, Reisdorph N, McQueen MB, Chonchol M and Seals DR, 2018. Chronic nicotinamide riboside supplementation is well-tolerated and elevates $N A D(+)$ in healthy middle-aged and older adults. Nature Communications, 9, 1286. https://doi.org/10.1038/s41467-018-03421-7

Nacarelli T, Lau L, Fukumoto T, Zundell J, Fatkhutdinov N, Wu S, Aird KM, Iwasaki O, Kossenkov AV, Schultz D, Noma KI, Baur JA, Schug Z, Tang HY, Speicher DW, David G and Zhang R, 2019. NAD(+) metabolism governs the proinflammatory senescence-associated secretome. Nature Cell Biology, 21, 397-407. https://doi.org/10. 1038/s41556-019-0287-4

Olsson AR, Sheng Y, Pero RW, Chaplin DJ and Horsman MR, 1996. DNA damage and repair in tumour and non-tumour tissues of mice induced by nicotinamide. British Journal of Cancer, 74, 368-373. https://doi.org/ 10.1038/bjc.1996.367

Pamukcu AM, Milli U and Bryan GT, 1981. Protective effect of nicotinamide on bracken fern induced carcinogenicity in rats. Nutrition and Cancer, 3, 86-93. https://doi.org/10.1080/01635588109513707

Pandey A (Syngene International Limited), 2016. In vivo Mammalian Erythrocyte Micronucleus Test in Rat with Niagen. Bangalore, India. $78 \mathrm{pp}$.

Poljsak $\mathrm{B}, 2016 . \mathrm{NAD}^{+}$in cancer prevention and treatment: pros and cons. Journal of Clinical \& Experimental Oncology, 2016, 1-15. 
Pour PM and Lawson T, 1984. Modification of pancreatic carcinogenesis in the hamster model. XV. Preventive effect of nicotinamide. Journal of the National Cancer Institute, 73, 767-770.

Rakieten N, Gordon BS, Beaty A, Cooney DA, Davis RD and Schein PS, 1971. Pancreatic islet cell tumors produced by the combined action of streptozotocin and nicotinamide. Proceedings of the Society for Experimental Biology and Medicine, 137, 280-283. https://doi.org/10.3181/00379727-137-35561

Rakieten N, Gordon BS, Beaty A, Cooney DA, Schein PS and Dixon RL, 1976. Modification of renal tumorigenic effect of streptozotocin by nicotinamide: spontaneous reversibility of streptozotocin diabetes. Proceedings of the Society for Experimental Biology and Medicine, 151, 356-361. https://doi.org/10.3181/00379727-15139209

Remie CME, Roumans KHM, Moonen MPB, Connell NJ, Havekes B, Mevenkamp J, Lindeboom L, de Wit VHW, van de Weijer T, Aarts S, Lutgens E, Schomakers BV, Elfrink HL, Zapata-Perez R, Houtkooper RH, Auwerx J, Hoeks J, Schrauwen-Hinderling VB, Phielix E and Schrauwen P, 2020. Nicotinamide riboside supplementation alters body composition and skeletal muscle acetylcarnitine concentrations in healthy obese humans. American Journal of Clinical Nutrition, 112, 413-426. https://doi.org/10.1093/ajcn/nqaa072

Roe FJ, 1962. Effect of massive doses of riboflavin, and other vitamins of the B group, on skin carcinogenesis in mice. British Journal of Cancer, 16, 252-257. https://doi.org/10.1038/bjc.1962.29

Rosenberg MR, Novicki DL, Jirtle RL, Novotny A and Michalopoulos G, 1985. Promoting effect of nicotinamide on the development of renal tubular cell tumors in rats initiated with diethylnitrosamine. Cancer Research, 45, 809-814.

SCF (Scientific Committee on Food), 2002. Opinion of the Scientific Committee on Food on the tolerable upper intake level of nicotinic acid and nicotinamide (niacin). $13 \mathrm{pp}$.

Schacter G (KGK Science, Inc.), 2018. A Randomized, Double-Blind, Placebo-Controlled Parallel Study Investigating the Effects of NIAGEN ${ }^{\circledR}$ (Nicotinamide Riboside Chloride) on NIAGEN $®$ Metabolites in Healthy Adults. London, Ontario, Canada. 313 pp.

Schmahl D and Stackelberg S, 1968. [The effect of lactoflavin, nicotinic acid amide or dipyridamol on the cancerogenic action of diethylnitrosamine in rats]. Arzneimittel-Forschung, 18, 318-320.

Schoental R, 1977. The role of nicotinamide and of certain other modifying factors in diethylnitrosamine carcinogenesis: fusaria mycotoxins and "spontaneous" tumors in animals and man. Cancer, 40, 1833-1840. https://doi.org/10.1002/1097-0142(197710)40:4+<1833:aid-cncr2820400810>3.0.c0;2-I

Sun WP, Li D, Lun YZ, Gong XJ, Sun SX, Guo M, Jing LX, Zhang LB, Xiao FC and Zhou SS, 2012. Excess nicotinamide inhibits methylation-mediated degradation of catecholamines in normotensives and hypertensives. Hypertension Research, 35, 180-185. https://doi.org/10.1038/hr.2011.151

Sun WP, Zhai MZ, Li D, Zhou Y, Chen NN, Guo M and Zhou SS, 2017. Comparison of the effects of nicotinic acid and nicotinamide degradation on plasma betaine and choline levels. Clinical Nutrition, 36, 1136-1142. https:// doi.org/10.1016/j.clnu.2016.07.016

Surjana D, Halliday GM and Damian DL, 2010. Role of nicotinamide in DNA damage, mutagenesis, and DNA repair. Journal of Nucleic Acids, 2010. https://doi.org/10.4061/2010/157591

Thorsrud B (Experimur), 2017. Oral 7-Day Dose Range Finding Toxicity Study in Juvenile Dogs with NIAGEN ${ }^{\circledR}$. Chicago, IL, USA. 172 pp.

Thorsrud B (Experimur), 2018. Oral 28-Day Toxicity Study in Juvenile Dogs with NIAGEN ${ }^{\circledR}$. Chicago, IL, USA. 388 pp.

Tian YJ, Li D, Ma Q, Gu XY, Guo M, Lun YZ, Sun WP, Wang XY, Cao Y and Zhou SS, 2013. Excess nicotinamide increases plasma serotonin and histamine levels. Sheng Li Xue Bao: [Acta Physiologica Sinica], 65, 33-38.

Tian YJ, Luo N, Chen NN, Lun YZ, Gu XY, Li Z, Ma Q and Zhou SS, 2014. Maternal nicotinamide supplementation causes global DNA hypomethylation, uracil hypo-incorporation and gene expression changes in fetal rats. British Journal of Nutrition, 111, 1594-1601. https://doi.org/10.1017/S0007114513004054

Toth B, 1983. Lack of carcinogenicity of nicotinamide and isonicotinamide following lifelong administration to mice. Oncology, 40, 72-75. https://doi.org/10.1159/000225695

Trammell SA, Schmidt MS, Weidemann BJ, Redpath P, Jaksch F, Dellinger RW, Li Z, Abel ED, Migaud ME and Brenner $C$, 2016. Nicotinamide riboside is uniquely and orally bioavailable in mice and humans. Nature Communications, 7, 12948. https://doi.org/10.1038/ncomms12948

Wilson D (KGK Synergize, Inc.), 2015. Randomized, Double-blind, Cross-over Study of the Pharmacokinetics of Three Dosages of Niagen ${ }^{\mathrm{TM}}$ in Healthy Subjects. London, Ontario, Canada. $212 \mathrm{pp}$.

Zhang Y, Ma T and Zhang P, 2018. Efficacy and safety of nicotinamide on phosphorus metabolism in hemodialysis patients: a systematic review and meta-analysis. Medicine (Baltimore), 97. https://doi.org/10.1097/MD. 0000000000012731

\title{
Abbreviations
}

\author{
1-MNM 1-methylnicotinamide \\ 2-PYR 1-methyl-2-pyridone-5-carboxamide \\ 4-PYR 1-methyl-4-pyridone-5-carboxamide \\ ADI acceptable daily intake
}


ADME absorption, distribution, metabolism and excretion

AOAC Association of Official Analytical Chemists

BMD benchmark dose

BMDL benchmark dose lower confidence limit

BMDU benchmark dose upper confidence limit

BMR benchmark response

bw body weight

CFU colony forming units

DEN diethylnitrosamine

DNA deoxyribonucleic acid

FID Flame Ionisation Detector

FSMP foods for special medical purposes

GC Gas Chromatography

GLP Good Laboratory Practice

GMP Good Manufacturing Practice

GRAS generally recognised as safe

HPLC High Performance Liquid Chromatography

ICP-MS Inductively Coupled Plasma mass Spectrometry

LNHPD Licensed Natural Health Products Database

LS literature search

MoE margin of exposure

NA nicotinic acid

NAAD nicotinic acid adenine dinucelotide

NAD+ nicotinamide adenine dinucleotide

NAM nicotinamide

NDA Panel on Nutrition, Novel Foods and Food Allergens

NDI new dietary ingredient

$\mathrm{NE} \quad$ niacin equivalent

NF novel food

NMN nicotinamide mononucleotide

NMR Nuclear Magnetic Resonance

NOAEL no observed adverse effect level

NRC nicotinamide riboside chloride

OECD Organisation for Economic Co-operation and Development

$\mathrm{RH} \quad$ relative humidity

RP reference point

SCF Scientific Committee on Food

TDRWC total diet replacements products for weight control

UCT University of Chemistry and Technology (Prague)

UL tolerable upper intake level

USP United States Pharmacopeia

UV ultra violet 


\section{Appendix A - Overview of toxicological studies on the NF}

\begin{tabular}{|c|c|c|c|c|}
\hline Reference & Type of study & Test system & Dose of NRC & Findings and conclusions $^{(a)}$ \\
\hline $\begin{array}{l}\text { Study No. S15004 (Unpublished) } \\
\text { (Kamath, 2015; Conze et al., 2016) }\end{array}$ & $\begin{array}{l}\text { Bacterial reverse mutation } \\
\text { test (GLP, OECD TG 471) }\end{array}$ & $\begin{array}{l}\text { Salmonella Typhimurium and } \\
\text { Escherichia coli }\end{array}$ & $\begin{array}{l}\text { Up to } 5 \mathrm{mg} / \text { plate (absence } \\
\text { and presence of S9 mix) }\end{array}$ & Not mutagenic \\
\hline $\begin{array}{l}\text { Study No. S15005 (Unpublished) } \\
\text { (Conze et al., 2016; Kamath, 2016) }\end{array}$ & $\begin{array}{l}\text { In vitro mammalian } \\
\text { chromosome aberration test } \\
(\mathrm{GLP}, \mathrm{OECD} T \mathrm{TG} 473)\end{array}$ & $\begin{array}{l}\text { Human peripheral blood } \\
\text { lymphocyte }\end{array}$ & Up to $5 \mathrm{mg} / \mathrm{mL}$ & Not clastogenic \\
\hline $\begin{array}{l}\text { Study No. S15006 (Unpublished) } \\
\text { (Conze et al., 2016; Pandey, 2016) }\end{array}$ & $\begin{array}{l}\text { In vivo mammalian } \\
\text { erythrocyte micronucleus } \\
\text { test (GLP, OECD TG 474) }\end{array}$ & Sprague-Dawley rats & Up to $2,000 \mathrm{mg} / \mathrm{kg} \mathrm{bw}$ & $\begin{array}{l}\text { No bone marrow toxicity; does not } \\
\text { induce micronuclei }\end{array}$ \\
\hline $\begin{array}{l}\text { Study No. S13101 (Unpublished) } \\
\text { (Bhoite and Jayachandra, 2014; } \\
\text { Conze et al., 2016) }\end{array}$ & $\begin{array}{l}\text { Single dose oral toxicity } \\
\text { study (GLP) }\end{array}$ & $\begin{array}{l}\text { Sprague-Dawley rats ( } 5 / \text { sex per } \\
\text { group) }\end{array}$ & $5,000 \mathrm{mg} / \mathrm{kg} \mathrm{bw}$ & $\begin{array}{l}\text { f: } \downarrow(3 \%) \text { cumulative bw gain in vs. } \\
\text { control group }\end{array}$ \\
\hline $\begin{array}{l}\text { Study No. SN17-921 (Unpublished) } \\
\text { (Thorsrud, 2017) }\end{array}$ & $\begin{array}{l}\text { 7-day dose range finding } \\
\text { oral toxicity study (GLP) }\end{array}$ & Juvenile dogs (2/sex per group) & $\begin{array}{l}0,100,300 \text { and } 1,000 \mathrm{mg} / \\
\mathrm{kg} \text { bw per day }\end{array}$ & No toxicologically relevant findings \\
\hline $\begin{array}{l}\text { Study No. S13120 (Unpublished) } \\
\text { (Bhoite and Jayachandra, 2014; } \\
\text { Conze et al., 2016) }\end{array}$ & $\begin{array}{l}\text { 14-day dose range finding } \\
\text { oral toxicity study (non-GLP) }\end{array}$ & $\begin{array}{l}\text { Sprague-Dawley rats ( } 5 / \text { sex per } \\
\text { group) }\end{array}$ & $\begin{array}{l}0,750,1,500,2,500, \text { or } \\
5,000 \mathrm{mg} / \mathrm{kg} \text { bw per day, by } \\
\text { gavage }\end{array}$ & $\begin{array}{l}\mathrm{m}: \text { bw } \downarrow \text { in dose groups } 1,500,2,500 \\
\text { and } 5,000 \mathrm{mg} / \mathrm{kg} \text { bw per day vs. control } \\
\text { group at different time points; overall } \\
\text { food consumption } \downarrow \text { in dose group } \\
5,000 \mathrm{mg} / \mathrm{kg} \text { bw per day }\end{array}$ \\
\hline $\begin{array}{l}\text { Study No. SN17-940 (Unpublished) } \\
\text { (Thorsrud, 2018) }\end{array}$ & $\begin{array}{l}\text { 28-day oral toxicity study } \\
\text { (GLP) }\end{array}$ & $\begin{array}{l}\text { Juvenile dogs (test animals: } \\
\text { 4/sex per group; TK satellite } \\
\text { animals: } 2 / \text { sex per group) }\end{array}$ & $\begin{array}{l}0,100,300 \text { or } 1,000 \mathrm{mg} / \mathrm{kg} \\
\text { bw per day, by gavage }\end{array}$ & $\begin{array}{l}\mathrm{m}+\mathrm{f} \text { : bw } \downarrow \text { and salivation after dosing, } \\
\text { abdominal contractions, diarrhoea and } \\
\text { vomiting (high-dose group). After } \\
\text { lowering the dose from } 1,000 \text { to } 500 \\
\mathrm{mg} / \mathrm{kg} \text { bw per day, salivation and } \\
\text { vomiting still occurred. } \\
\text { m: prothrombin time } \downarrow \text { (low-dose group, } \\
\text { not clearly dose-related); glucose } \downarrow \text { (mid- } \\
\text { dose group, not clearly dose-related); Na } \\
\downarrow, \mathrm{K} \downarrow \text {, eosinophils } \downarrow \text {, absolute and } \\
\text { relative testes and thyroid weights } \downarrow \\
\text { (high-dose group) } \\
\text { f: } \uparrow \text { AST, } \downarrow \text { phosphate, } \downarrow \text { fibrin, } \uparrow \text { relative } \\
\text { ovary weight (high-dose group) } \\
\text { NOAEL }=300 \text { mg/kg bw per day }\end{array}$ \\
\hline
\end{tabular}




\begin{tabular}{|c|c|c|c|c|}
\hline Reference & Type of study & Test system & Dose of NRC & Findings and conclusions $^{(a)}$ \\
\hline $\begin{array}{l}\text { Study No. S14022 (Unpublished) } \\
\text { (Bhoite et al., 2015; Conze et al., } \\
\text { 2016) }\end{array}$ & $\begin{array}{l}\text { 90-day repeated dose oral } \\
\text { toxicity study (GLP, OECD TG } \\
408)\end{array}$ & $\begin{array}{l}\text { Sprague-Dawley rats (10/sex } \\
\text { per group) }\end{array}$ & $\begin{array}{l}0,100,300 \text { or } 3,000 \mathrm{mg} / \mathrm{kg} \\
\text { bw per day }\end{array}$ & $\begin{array}{l}\mathrm{m}+\mathrm{f} \text { : neutrophils } \uparrow \text {, ALT } \uparrow \text {, triglycerides } \\
\uparrow, \text { rel. liver weight } \uparrow \text {, rel. kidney weight } \uparrow \\
\text { (mid and high-dose groups); } \\
\text { hepatocellular hypertrophy and necrosis, } \\
\text { thyroid follicular cell hypertrophy, } \\
\text { hypertrophy of cortical zona glomerulosa } \\
\text { in adrenals (high-dose group) } \\
\text { m: bw } \downarrow \text { (dose-related), feed } \\
\text { consumption } \downarrow \text { (high-dose group; low } \\
\text { and mid dose groups sometimes); } \\
\text { leucocytes } \uparrow \text { (mid and high-dose } \\
\text { groups); ALP } \uparrow, \text { bile acids } \uparrow \text {, absolute } \\
\text { liver weight } \uparrow, \text { absolute and relative } \\
\text { testes weight } \downarrow \text {, absolute and relative } \\
\text { epididymis weight } \downarrow \text {, chronic progressive } \\
\text { nephropathy, tubular degeneration/ } \\
\text { atrophy of testes, reduced luminal sperm } \\
\text { in epididymis and cellular debris (high- } \\
\text { dose group) } \\
\text { f: AST } \uparrow, \text { ALP } \uparrow, \text { leucocytes } \uparrow \text { (mid and } \\
\text { high dose group); feed consumption } \downarrow \\
\text { (sometimes), monocytes } \uparrow, \text { GGT } \uparrow, \\
\text { relative ovary weight } \uparrow, \text { hypertrophy of } \\
\text { corpora lutea (high-dose group) } \\
\text { NOAEL = } 300 \text { mg/kg bw per day }\end{array}$ \\
\hline $\begin{array}{l}\text { Study No. G10959 (Unpublished) } \\
\text { (Ganiger, 2016) }\end{array}$ & $\begin{array}{l}\text { One generation reproduction } \\
\text { toxicity study (GLP, OECD TG } \\
415 \text { ) }\end{array}$ & $\begin{array}{l}\text { Sprague-Dawley rats ( } 25 / \text { sex } \\
\text { per group) }\end{array}$ & $\begin{array}{l}0,3,000,6,000 \text { and } \\
12,000 \mathrm{mg} / \mathrm{kg} \text { feed in the } \\
\text { diet (ad libitum) } \\
\text { (corresponding to } 169,334 \\
\text { and } 675 \mathrm{mg} / \mathrm{kg} \text { bw per day } \\
\text { in males and } 273,543 \text { and } \\
1,088 \mathrm{mg} / \mathrm{kg} \text { bw per day in } \\
\text { females) }\end{array}$ & $\begin{array}{l}\text { m: bw } \downarrow \text {, feed consumption } \downarrow \text { (at two } \\
\text { time points) (high dose group) } \\
\text { No effect on precoital time, gestation } \\
\text { length, fertility parameters, pathological } \\
\text { and histopathological examinations of } \\
\text { reproductive organs of adult rats, } \\
\text { survival and abnormalities in life and } \\
\text { death at any dose } \\
\text { NOAEL }=675 \mathrm{mg} / \mathrm{kg} \text { bw per day in } \\
\text { males and } 1,088 \mathrm{mg} / \mathrm{kg} \text { bw per day in } \\
\text { females for fertility and reproductive } \\
\text { performance }\end{array}$ \\
\hline
\end{tabular}




\begin{tabular}{|c|c|c|c|c|}
\hline Reference & Type of study & Test system & Dose of NRC & Findings and conclusions $^{(a)}$ \\
\hline $\begin{array}{l}\text { Study No. G10957 (Unpublished) } \\
\text { (Geetha Rao, 2016) }\end{array}$ & $\begin{array}{l}\text { Embryo-fetal developmental } \\
\text { toxicity study (GLP, OECD TG } \\
\text { 414) }\end{array}$ & $\begin{array}{l}\text { Sprague-Dawley pregnant rats } \\
\text { (24/group) }\end{array}$ & $\begin{array}{l}0,325,750 \text { and } 1,500 \mathrm{mg} / \\
\mathrm{kg} \text { bw per day, by gavage }\end{array}$ & $\begin{array}{l}\text { Maternal feed consumption } \downarrow \text {, maternal } \\
\text { bw } \downarrow \text {, maternal bw gain } \downarrow \text { (mid and high } \\
\text { dose groups); gravid uterine weight } \downarrow \\
\text { (high-dose group); late weight resorption } \\
\uparrow \text { (dose-related); mean fetal weight } \downarrow \\
\text { (mid- and high-dose groups) } \\
\text { Incidence of fetal anasarca } \uparrow, 2 \text { cases of } \\
\text { small fetuses, } 1 \text { fetus with moderate } \\
\text { flexed right forelimb, } 1 \text { fetus with thread- } \\
\text { like tail (high-dose group) } \\
\text { Delayed, incomplete or poor ossification } \\
\text { (dose-related) } \\
\text { Embryo/fetotoxicity findings observed at } \\
\text { a dose of } 750 \mathrm{mg} / \mathrm{kg} \text { bw per day } \\
\text { considered secondary to maternal } \\
\text { toxicity } \\
\text { NOAEL }=325 \mathrm{mg} / \mathrm{kg} \text { bw per day for } \\
\text { maternal and embryo/fetotoxicity }\end{array}$ \\
\hline
\end{tabular}

$\downarrow$ : decrease; $\uparrow$ : increase; bw: body weight; f: females; GLP: good laboratory practice; m: males; NRC: nicotinamide riboside chloride; OECD TG: Organisation for Economic Co-operation and Development test guidelines.

(a): Studies evaluated in the previous evaluation (EFSA NDA Panel, 2019). 


\section{Appendix B - Literature search on health effects of the intake of nicotinamide riboside chloride, nicotinamide and methyl nicotinamide}

An outsourced literature search following a search strategy and standard operating procedure as described by UCT Prague (Dibusz and Vejvodova, 2020) was conducted to investigate four main categories of health outcomes following exposure to nicotinamide riboside chloride: hepatic function, haematology parameters, methyl balance and carcinogenicity.

Four databases were searched on 28 October 2020. Due to the very small number of articles available for nicotinamide riboside chloride, the search string also included three related metabolites. The search terms were: "nicotinamide riboside chloride" or "23111-00-4" or "nicotinamide" or "98-920 " or "nicotinamide riboside" or "1341-23-7" or "methyl-nicotinamide" or "114-33-0". The number of articles available for nicotinamide being very large, the following restrictions was applied for this compound only:

- Scopus: added the search term "toxic".

- Pubmed: added the search term "toxic actions" [Medical Subject Headings (MeSH $\left.{ }^{\circledR}\right)$ Major Topic].

- Web of Science: search limited to Toxicology.

- SciFinder: search limited to CAS number and Toxicology.

The number of hits in each database is reported below.

\begin{tabular}{l|c}
\hline Database & Number of hits in the database \\
\hline Web of Science & 5,989 \\
\hline Scopus & 687 \\
\hline Chemical Abstracts (SciFinder) & 5,443 \\
\hline Pubmed & 1,012 \\
\hline Unique number of articles & 10,400 \\
\hline
\end{tabular}

A stepwise abstract evaluation methodology was carried out as follows:

1) Articles were sorted by default weighed keywords (predefined for chemicals by the EFSA NF team) as well as custom-weighed keywords applicable to the particular NF (transaminase, aminotransferase, AST, ASAT, ALT, ALAT, alkaline phosphatase, ALP, bilirubin, BR, serum, blood, thrombocytopenia, platelet, homocysteine, S-adenosylmethionine, SAM, Sadenosylhomocysteine, SAH, betaine, SAM/SAH) [10,400 articles].

2) A list of articles containing the names 'nicotinamide riboside chloride' or '23111-00-4' OR 'nicotinamide' or ' $98-92-0$ ' or 'nicotinamide riboside' or '1341-23-7' or 'methyl-nicotinamide' or '114-33-0' in the title or in the abstract excluding patents was created [5,349 articles; referred to as standard list hereafter].

3) Several sublists of the standard list were created to focus the search on the desired areas of interest:

a) Hepatic function (using liver, hepat, transaminase, aminotransferase, AST, ASAT, ALT, ALAT, alkaline phosphatase, ALP, bilirubin or BR as keywords) [sublist 1; 1,002 articles].

b) Haematology (using serum, blood, haemat, heamat, thrombocytopenia or platelet as keywords) [sublist 2; 802 articles].

c) Methyl balance (using methyl, homocysteine, S-adenosylmethionine, SAM, Sadenosylhomocysteine, SAH, betaine, SAM/SAH as keywords) [sublist 3; 1337 articles].

d) Carcinogenicity (using cancer, carcino, tumo(u)r as keywords) [sublist 4; 681 articles].

4) Following a review of the abstracts in the top 100 of the standard list and the abstracts in the four sublists, several additional sublists of the standard list were created to capture relevant articles related to:

a) Haematology (using thrombocytopenia or platelet as keywords [sublist 5; 49 articles].

b) Methyl balance (using homocysteine as keyword) [sublist 6; 30 articles].

c) Carcinogenicity (using carcino as keyword) [sublist 7; 177 articles].

d) Carcinogenicity (using tumour as keyword) [sublist 8; 47 articles]. 
e) Sublist 9 was created to capture relevant articles specific to the NF (using nicotinamide riboside chloride as keyword) [7 articles].

f) Sublist 10 was created to reduce the noise brought in by the very large nicotinamide data set (using nicotinamide riboside or methyl-nicotinamide as keywords) [1,473 articles].

5) Within the sublists, evaluation of titles and abstracts sorted by their relevance (keywords) was carried out by both the contractor (varying number of references for each sublist) and the SO in charge of the dossier (top 100 references for each sublist).

6) In total, 51 relevant articles were identified by the contractor, and 27 additional articles were identified by the SO in charge of the dossier, bringing the total to 78 articles of interest, listed hereafter.

\section{List of articles identified through the LS}

1) Al-Gayyar MMH, Bagalagel A, Noor AO, Almasri DM and Diri R, 2019. The therapeutic effects of nicotinamide in hepatocellular carcinoma through blocking IGF-1 and effecting the balance between Nrf2 and PKB. Biomedicine and Pharmacotherapy, 112, 108653. https:// doi.org/10.1016/j.biopha.2019.108653

2) Bashandy $S A E$, Ebaid $H$, Abdelmottaleb Moussa SA, Alhazza IM, Hassan I, Alaamer A and Al Tamimi J, 2018. Potential effects of the combination of nicotinamide, vitamin B2 and vitamin $\mathrm{C}$ on oxidative-mediated hepatotoxicity induced by thioacetamide. Lipids in Health and Disease, 17, 29. https://doi.org/10.1186/s12944-018-0674-z

3) Bernier J, Denekamp J, Rojas A, Trovo M, Horiot JC, Hamers H, Antognoni P, Dahl O, Richaud P, Kaanders J, van Glabbeke M and Pierart M, 1999. ARCON: accelerated radiotherapy with carbogen and nicotinamide in non small cell lung cancer: a phase I/II study by the EORTC. Radiotherapy and Oncology, 52, 149-156. https://doi.org/10.1016/ s0167-8140(99)00106-1

4) Braidy $\mathrm{N}$ and Liu $\mathrm{Y}, 2020$ a. Can nicotinamide riboside protect against cognitive impairment? Current Opinion in Clinical Nutrition and Metabolic Care, 23, 413-420. https://doi.org/10. 1097/MCO.0000000000000691

5) Braidy $N$ and Liu $Y, 2020 \mathrm{~b}$. NAD ${ }^{+}$therapy in age-related degenerative disorders: a benefit/ risk analysis. Experimental Gerontology, 132, 110831. https://doi.org/10.1016/j.exger.2020. 110831

6) Bryan GT, 1986. The influence of niacin and nicotinamide on in vivo carcinogenesis. Advances in Experimental Medicine and Biology, 206, 331-338. https://doi.org/10.1007/9781-4613-1835-4_24

7) Chen AC, Martin AJ, Choy B, Fernandez-Penas $P$, Dalziell RA, McKenzie CA, Scolyer RA, Dhillon HM, Vardy JL, Kricker A, St George G, Chinniah N, Halliday GM and Damian DL, 2015. A phase 3 randomized trial of nicotinamide for skin-cancer chemoprevention. The New England Journal of Medicine, 373, 1618-1626. https://doi.org/10.1056/ NEJMoa1506197

8) Chlopicki S, Swies J, Mogielnicki A, Buczko W, Bartus M, Lomnicka M, Adamus J and Gebicki J, 2007. 1-Methylnicotinamide (MNA), a primary metabolite of nicotinamide, exerts antithrombotic activity mediated by a cyclooxygenase-2/prostacyclin pathway. British Journal of Pharmacology, 152, 230-239. https://doi.org/10.1038/sj.bjp.0707383

9) Conze $D$, Brenner $C$ and Kruger $C L$, 2019. Safety and metabolism of long-term administration of NIAGEN (nicotinamide riboside chloride) in a randomized, double-blind, placebo-controlled clinical trial of healthy overweight adults. Scientific Reports, 9, 9772. https://doi.org/10.1038/s41598-019-46120-z

10) Conze $\mathrm{DB}$, Crespo-Barreto $\mathrm{J}$ and Kruger $\mathrm{CL}$, 2016. Safety assessment of nicotinamide riboside, a form of vitamin B3. Human and Experimental Toxicology, 35, 1149-1160. https://doi.org/10.1177/0960327115626254

11) Cosmetic Ingredient Review Expert $P, 2005$. Final report of the safety assessment of niacinamide and niacin. International Journal of Toxicology, 24(Suppl 5), 1-31. https://doi. org/10.1080/10915810500434183

12) Damian $D L$, 2017. Nicotinamide for skin cancer chemoprevention. Australasian Journal of Dermatology, 58, 174-180. https://doi.org/10.1111/ajd.12631 
13) de Castro JM, Assumpcao JAF, Stein DJ, Toledo RS, da Silva LS, Caumo W, Carraro CC, da Rosa Araujo AS and Torres ILS, 2020. Nicotinamide riboside reduces cardiometabolic risk factors and modulates cardiac oxidative stress in obese Wistar rats under caloric restriction. Life Sciences, 263, 118596. https://doi.org/10.1016/j.lfs.2020.118596

14) Delabie W, Maes W, Devloo R, Van den Hauwe MR, Vanhoorelbeke K, Compernolle V and Feys HB, 2020. The senotherapeutic nicotinamide riboside raises platelet nicotinamide adenine dinucleotide levels but cannot prevent storage lesion. Transfusion, 60, 165-174. https://doi.org/10.1111/trf.15556

15) Eckert MA, Coscia F, Chryplewicz A, Chang JW, Hernandez KM, Pan S, Tienda SM, Nahotko DA, Li G, Blazenovic I, Lastra RR, Curtis M, Yamada SD, Perets R, McGregor SM, Andrade J, Fiehn O, Moellering RE, Mann M and Lengyel E, 2019. Proteomics reveals NNMT as a master metabolic regulator of cancer-associated fibroblasts. Nature, 569, 723-728. https://doi.org/ 10.1038/s41586-019-1173-8

16) EFSA NDA Panel (EFSA Panel on Dietetic Products, Nutrition and Allergies), Allergies, Turck $D$, Bresson JL, Burlingame B, Dean T, Fairweather-Tait S, Heinonen M, Hirsch-Ernst KI, Mangelsdorf I, McArdle HJ, Naska A, Neuhauser-Berthold M, Nowicka G, Pentieva K, Sanz Y, Siani A, Sjodin A, Stern M, Tome D, Vinceti M, Willatts P, Engel KH, Marchelli R, Poting A, Poulsen M, Schlatter JR, Gelbmann W, Ververis E and van Loveren H, 2017. Safety of 1methylnicotinamide chloride (1-MNA) as a novel food pursuant to Regulation (EC) No 258/ 97. EFSA Journal 2017;15(10):e05001. https://doi.org/10.2903/j.efsa.2017.5001

17) Fania L, Mazzanti C, Campione E, Candi E, Abeni D and Dellambra E, 2019. Role of nicotinamide in genomic stability and skin cancer chemoprevention. International Journal of Molecular Sciences, 20. https://doi.org/10.3390/ijms20235946

18) Gong B, Pan $Y$, Vempati $P$, Zhao W, Knable L, Ho L, Wang J, Sastre M, Ono K, Sauve AA and Pasinetti GM, 2013. Nicotinamide riboside restores cognition through an upregulation of proliferator-activated receptor-gamma coactivator 1alpha regulated beta-secretase 1 degradation and mitochondrial gene expression in Alzheimer's mouse models. Neurobiol Aging, 34, 1581-1588. https://doi.org/10.1016/j.neurobiolaging.2012.12.005

19) Hageman GJ and Stierum RH, 2001. Niacin, poly(ADP-ribose) polymerase-1 and genomic stability. Mutation Research, 475, 45-56. https://doi.org/10.1016/s0027-5107(01)00078-1

20) Hageman GJ, Stierum RH, van Herwijnen MH, van der Veer MS and Kleinjans JC, 1998. Nicotinic acid supplementation: effects on niacin status, cytogenetic damage, and poly(ADPribosylation) in lymphocytes of smokers. Nutrition and Cancer, 32, 113-120. https://doi.org/ $10.1080 / 01635589809514728$

21) Han X, Bao X, Lou Q, Xie X, Zhang M, Zhou S, Guo H, Jiang G and Shi Q, 2019. Nicotinamide riboside exerts protective effect against aging-induced NAFLD-like hepatic dysfunction in mice. Peer], 7, e7568. https://doi.org/10.7717/peerj.7568

22) Horsman MR, Hoyer M, Honess DJ, Dennis IF and Overgaard J, 1993. Nicotinamide pharmacokinetics in humans and mice: a comparative assessment and the implications for radiotherapy. Radiotherapy and Oncology, 27, 131-139. https://doi.org/10.1016/0167-8140 (93)90133-s

23) Horsman MR, Khalil AA, Chaplin DJ and Overgaard J, 1995. The ability of nicotinamide to inhibit the growth of a C3H mouse mammary carcinoma. Acta Oncologica, 34, 443-446. https://doi.org/10.3109/02841869509094006

24) Hoskin PJ, Rojas AM, Saunders MI, Bentzen SM, Motohashi KJ and investigators B, 2009. Carbogen and nicotinamide in locally advanced bladder cancer: early results of a phase-III randomized trial. Radiotherapy and Oncology, 91, 120-125. https://doi.org/10.1016/j. radonc.2008.10.001

25) Hoskin PJ, Stratford MR, Saunders MI, Hall DW, Dennis MF and Rojas A, 1995. Administration of nicotinamide during chart: pharmacokinetics, dose escalation, and clinical toxicity. International Journal of Radiation Oncology, Biology, Physics, 32, 1111-1119. https://doi.org/10.1016/0360-3016(95)00022-q

26) Huang J, Schaefer J, Wang $Y$, Gioia L, Pei $Y$, Shi $X$, Waris S, Zhao C, Nguyen J and Du J, 2020. Metabolic signature of eyelid basal cell carcinoma. Experimental Eye Research, 198, 108140. https://doi.org/10.1016/j.exer.2020.108140

27) Jablonska P, Mierzejewska P, Kutryb-Zajac B, Rzyman W, Dziadziuszko R, Polanska J, Sitkiewicz M, Smolenski RT and Slominska EM, 2019. Increased plasma concentration of 4pyridone-3-carboxamide-1-ss-D-ribonucleoside (4PYR) in lung cancer. Preliminary studies. 
Nucleosides, Nucleotides and Nucleic Acids, 38, 781-787. https://doi.org/10.1080/ 15257770.2019 .1600705

28) Jackson TM, Rawling JM, Roebuck BD and Kirkland JB, 1995. Large supplements of nicotinic acid and nicotinamide increase tissue $\mathrm{NAD}^{+}$and poly(ADP-ribose) levels but do not affect diethylnitrosamine-induced altered hepatic foci in Fischer-344 rats. The Journal of Nutrition, 125, 1455-1461. https://doi.org/10.1093/jn/125.6.1455

29) Jacobson EL, Shieh WM and Huang AC, 1999. Mapping the role of NAD metabolism in prevention and treatment of carcinogenesis. Molecular and Cellular Biochemistry, 193, 69-74.

30) Jiang $Y$, Liu $Y$, Wang $Z$, Xue $M$, Chang $Z$ and Liang $H$, 2020. Alleviating effect of nicotinamide ribose on depressed-like behavior and intestinal mucosal permeability in alcohol-exposed mice. 41. https://doi.org/10.7506/spkx1002-6630-20190630-439

31) Kjellen $E$, Joiner MC, Collier JM, Johns $H$ and Rojas A, 1991. A therapeutic benefit from combining normobaric carbogen or oxygen with nicotinamide in fractionated X-ray treatments. Radiotherapy and Oncology, 22, 81-91. https://doi.org/10.1016/0167-8140(91) 90002-x

32) Knip $M$, Douek IF, Moore WP, Gillmor HA, McLean AE, Bingley PJ, Gale EA and European Nicotinamide Diabetes Intervention Trial G, 2000. Safety of high-dose nicotinamide: a review. Diabetologia, 43, 1337-1345. https://doi.org/10.1007/s001250051536

33) Kourtzidis IA, Stoupas AT, Gioris IS, Veskoukis AS, Margaritelis NV, Tsantarliotou M, Taitzoglou I, Vrabas IS, Paschalis V, Kyparos A and Nikolaidis MG, 2016. The NAD(+) precursor nicotinamide riboside decreases exercise performance in rats. Journal of the International Society of Sports Nutrition, 13, 32. https://doi.org/10.1186/s12970-016-0143-x

34) Kroger $\mathrm{H}$ and Gratz $\mathrm{R}$, 1983. [Effect of L-tryptophan, nicotinamide, L-methionine and 1methylnicotinamide on the embryotoxic effect of various substances]. Arzneimittelforschung, 33, 915-919.

35) Lecomte C, Vendrely B, Miremont-Salame G, Combe C and Haramburu F, 2006. Nicotinamide and thrombocytopenia? Drug Safety, 29.

36) Lee HJ, Hong YS, Jun $W$ and Yang SJ, 2015. Nicotinamide riboside ameliorates hepatic metaflammation by modulating NLRP3 inflammasome in a rodent model of type 2 diabetes. Journal of Medicinal Food, 18, 1207-1213. https://doi.org/10.1089/jmf.2015.3439

37) Lee $\mathrm{HJ}$ and Yang SJ, 2019. Nicotinamide riboside regulates inflammation and mitochondrial markers in AML12 hepatocytes. Nutrition Research and Practice, 13, 3-10. https://doi.org/ 10.4162/nrp.2019.13.1.3

38) Li D, Tian YJ, Guo J, Sun WP, Lun YZ, Guo M, Luo N, Cao Y, Cao JM, Gong XJ and Zhou SS, 2013. Nicotinamide supplementation induces detrimental metabolic and epigenetic changes in developing rats. British Journal of Nutrition, 110, 2156-2164. https://doi.org/10.1017/ S0007114513001815

39) Mateuszuk L, Jasztal A, Maslak E, Gasior-Glogowska M, Baranska M, Sitek B, Kostogrys R, Zakrzewska A, Kij A, Walczak M and Chlopicki S, 2016. Antiatherosclerotic effects of 1methylnicotinamide in apolipoprotein E/low-density lipoprotein receptor-deficient mice: a comparison with nicotinic acid. Journal of Pharmacology and Experimental Therapeutics, 356, 514-524. https://doi.org/10.1124/jpet.115.228643

40) Miralbell R, Mornex F, Greiner R, Bolla M, Storme G, Hulshof M, Bernier J, Denekamp J, Rojas AM, Pierart M, van Glabbeke M and Mirimanoff RO, 1999. Accelerated radiotherapy, carbogen, and nicotinamide in glioblastoma multiforme: report of European Organization for Research and Treatment of Cancer trial 22933. Journal of Clinical Oncology, 17, 3143-3149. https://doi.org/10.1200/JCO.1999.17.10.3143

41) Mogielnicki $A$, Kramkowski K, Pietrzak $L$ and Buczko W, 2007. N-methylnicotinamide inhibits arterial thrombosis in hypertensive rats. Journal of Physiology and Pharmacology, 58, 515527.

42) Mori $Y$, Sugawara A, Tsuji M, Kakamu T, Tsuboi S, Kanda H, Hayakawa $T$ and Fukushima $T$, 2012. Toxic effects of nicotinamide methylation on mouse brain striatum neuronal cells and its relation to manganese. Environmental Health and Preventive Medicine, 17, 371-376. https://doi.org/10.1007/s12199-011-0262-6

43) Nakagawa K, Miyazaki M, Okui K, Kato N, Moriyama $Y$ and Fujimura S, 1991. N1methylnicotinamide level in the blood after nicotinamide loading as further evidence for malignant tumor burden. Japanese Journal of Cancer Research, 82, 1277-1283. https://doi. org/10.1111/j.1349-7006.1991.tb01793.x 
44) Nofer J and Wronska-Szpakowa T, 1964. Biochemical disturbances produced by [chronic] carbon disulfide poisoning. Proceedings of the Intern. Congr. Occupational Health, 14th, Madrid, $803 \mathrm{pp}$.

45) Okabe $K$, Yaku K, Tobe $K$ and Nakagawa $T$, 2019. Implications of altered NAD metabolism in metabolic disorders. Journal of Biomedical Science, 26, 34. https://doi.org/10.1186/s12929019-0527-8

46) Olsson AR, Sheng Y, Pero RW, Chaplin DJ and Horsman MR, 1996. DNA damage and repair in tumour and non-tumour tissues of mice induced by nicotinamide. British Journal of cancer, 74, 368-373. https://doi.org/10.1038/bjc.1996.367

47) Park $\mathrm{KH}$ and $\mathrm{Kim} \mathrm{SH}, 2020$. Adult zebrafish as an in vivo drug testing model for ethanol induced acute hepatic injury. Biomedicine \& Pharmacotherapy, 132, 110836. https://doi.org/ 10.1016/j.biopha.2020.110836

48) Patwa J, Khan S and Jena G, 2020. Nicotinamide attenuates cyclophosphamide-induced hepatotoxicity in SD rats by reducing oxidative stress and apoptosis. Journal of Biochemical and Molecular Toxicology, 34, e22558. https://doi.org/10.1002/jbt.22558

49) Pelikant-Malecka I, Sielicka A, Kaniewska E, Smolenski RT and Slominska EM, 2015. Endothelial toxicity of unusual nucleotide metabolites. Pharmacological Reports, 67, 818 822. https://doi.org/10.1016/j.pharep.2015.03.020

50) Pham T, Bae M, Kim M-B, Lee Y, Hu S, Kang H, Park Y-K and Lee J-Y, 2019a. Nicotinamide riboside, an NAD + precursor, reduces hepatic stellate cell activation and attenuates liver fibrosis in a diet-induced mouse model of liver fibrosis (OR24-06-19). Current Developments in Nutrition, 3. https://doi.org/10.1093/cdn/nzz031.OR24-06-19

51) Pham TX, Bae M, Kim MB, Lee Y, Hu S, Kang H, Park YK and Lee JY, 2019b. Nicotinamide riboside, an $\mathrm{NAD}^{+}$precursor, attenuates the development of liver fibrosis in a diet-induced mouse model of liver fibrosis. Biochimica et Biophysica Acta (BBA)-Molecular Basis of Disease, 1865, 2451-2463. https://doi.org/10.1016/j.bbadis.2019.06.009

52) Pour PM and Lawson T, 1984. Modification of pancreatic carcinogenesis in the hamster model. XV. Preventive effect of nicotinamide. Journal of the National Cancer Institute, 73, 767-770.

53) Rawat D, Shrivastava S, Naik RA, Chhonker SK and Koiri RK, 2020. SIRT1-mediated amelioration of oxidative stress in kidney of alcohol-aflatoxin-B1-induced hepatocellular carcinoma by resveratrol is catalase dependent and GPx independent. Journal of Biochemical and Molecular Toxicology, 34, e22576. https://doi.org/10.1002/jbt.22576

54) Ray SD, Balasubramanian G, Bagchi D and Reddy CS, 2001. Ca(2+)-calmodulin antagonist chlorpromazine and poly(ADP-ribose) polymerase modulators 4-aminobenzamide and nicotinamide influence hepatic expression of $\mathrm{BCL}-\mathrm{XL}$ and $\mathrm{P} 53$ and protect against acetaminophen-induced programmed and unprogrammed cell death in mice. Free Radical Biology and Medicine, 31, 277-291. https://doi.org/10.1016/s0891-5849(01)00562-7

55) Reshma CS, Sruthi S, Syama S, Gayathri V and Mohanan PV, 2015. Assessing the systemic toxicity in rabbits after sub acute exposure to ocular irritant chemicals. Toxicological Research, 31, 49-59. https://doi.org/10.5487/TR.2015.31.1.049

56) Rottembourg JB, Launay-Vacher $\mathrm{V}$ and Massard J, 2005. Thrombocytopenia induced by nicotinamide in hemodialysis patients. Kidney International, 68, 2911-2912. https://doi.org/ 10.1111/j.1523-1755.2005.00583_8.x

57) Salic K, Gart E, Seidel F, Verschuren L, Caspers M, van Duyvenvoorde W, Wong KE, Keijer J, Bobeldijk-Pastorova I, Wielinga PY and Kleemann R, 2019. Combined Treatment with Lcarnitine and nicotinamide riboside improves hepatic metabolism and attenuates obesity and liver steatosis. International Journal of Molecular Sciences, 20. https://doi.org/10.3390/ ijms20184359

58) Schoental $R, 1977$. The role of nicotinamide and of certain other modifying factors in diethylnitrosamine carcinogenesis: fusaria mycotoxins and "spontaneous" tumors in animals and man. Cancer, 40, 1833-1840. https://doi.org/10.1002/1097-0142(197710)40:4+ $<1833:$ :aid-cncr2820400810>3.0.c0;2-I

59) Shahbazian H, Zafar Mohtashami A, Ghorbani A, Abbaspour MR, Belladi Musavi SS, Hayati F and Lashkarara GR, 2011. Oral nicotinamide reduces serum phosphorus, increases $\mathrm{HDL}$, and induces thrombocytopenia in hemodialysis patients: a double-blind randomized clinical trial. Nefrologia, 31, 58-65. https://doi.org/10.3265/Nefrologia.pre2010.Nov.10734 
60) Shi Y, Zhang L, Jiang R, Chen W, Zheng W, Chen L, Tang L, Li L, Li L, Tang W, Wang Y and Yu $Y$, 2012. Protective effects of nicotinamide against acetaminophen-induced acute liver injury. International Immunopharmacology, 14, 530-537. https://doi.org/10.1016/j.intimp. 2012.09.013

61) Siavashpour A, Khalvati B, Azarpira N, Mohammadi H, Niknahad H and Heidari R, 2020. Poly (ADP-ribose) polymerase-1 (PARP-1) overactivity plays a pathogenic role in bile acidsinduced nephrotoxicity in cholestatic rats. Toxicology Letters, 330, 144-158. https://doi.org/ 10.1016/j.toxlet.2020.05.012

62) Slomka M, Zieminska E and Lazarewicz J, 2008. Nicotinamide and 1-methylnicotinamide reduce homocysteine neurotoxicity in primary cultures of rat cerebellar granule cells. Acta Neurobiologiae Experimentalis, 68, 1-9.

63) Snaidr VA, Damian DL and Halliday GM, 2019. Nicotinamide for photoprotection and skin cancer chemoprevention: a review of efficacy and safety. Experimental Dermatology, 28 Suppl 1, 15-22. https://doi.org/10.1111/exd.13819

64) Sun WP, Zhai MZ, Li D, Zhou Y, Chen NN, Guo M and Zhou SS, 2017. Comparison of the effects of nicotinic acid and nicotinamide degradation on plasma betaine and choline levels. Clinical Nutrition, 36, 1136-1142. https://doi.org/10.1016/j.clnu.2016.07.016

65) Surjana D, Halliday GM and Damian DL, 2010. Role of nicotinamide in DNA damage, mutagenesis, and DNA repair. Journal of Nucleic Acids, 2010. https://doi.org/10.4061/2010/ 157591

66) Surjana D, Halliday GM and Damian DL, 2013. Nicotinamide enhances repair of ultraviolet radiation-induced DNA damage in human keratinocytes and ex vivo skin. Carcinogenesis, 34, 1144-1149. https://doi.org/10.1093/carcin/bgt017

67) Szepeshazi K, Lapis K, Jeney A, Szende B, Schawartz J, Ujhelyi E, Takacs J, Kovalszky I and Tompa A, 1978. Testing the effects of liver protection agents by a complex morphologicalbiochemical method. Kiserletes Orvostudomany, 30.

68) Tian YJ, Luo N, Chen NN, Lun YZ, Gu XY, Li Z, Ma Q and Zhou SS, 2014. Maternal nicotinamide supplementation causes global DNA hypomethylation, uracil hypo-incorporation and gene expression changes in fetal rats. British Journal of Nutrition, 111, 1594-1601. https://doi.org/10.1017/S0007114513004054

69) Weidele $K$, Beneke $S$ and Burkle $A, 2017$. The $N A D(+)$ precursor nicotinic acid improves genomic integrity in human peripheral blood mononuclear cells after X-irradiation. DNA Repair, 52, 12-23. https://doi.org/10.1016/j.dnarep.2017.02.001

70) Williams AC, Cartwright LS and Ramsden DB, 2005. Parkinson's disease: the first common neurological disease due to auto-intoxication? QJM, 98, 215-226. https://doi.org/10.1093/ qjmed/hci027

71) Williams AC and Ramsden DB, 2005. Nicotinamide homeostasis: a xenobiotic pathway that is key to development and degenerative diseases. Medical Hypotheses, 65, 353-362. https://doi.org/10.1016/j.mehy.2005.01.042

72) Xie J, Wan J, Jiang R, Lu H, Peng $X$ and Zhang L, 2013. Upregulation of Sirt1 in carbontetrachloride-induced acute liver injury. Drug and Chemical Toxicology, 36, 277-283. https:// doi.org/10.3109/01480545.2012.710630

73) Yang $Y$, Mohammed FS, Zhang $N$ and Sauve AA, 2019. Dihydronicotinamide riboside is a potent $\mathrm{NAD}(+)$ concentration enhancer in vitro and in vivo. Journal of Biological Chemistry, 294, 9295-9307. https://doi.org/10.1074/jbc.RA118.005772

74) Yin H, Hu M, Liang X, Ajmo JM, Li X, Bataller R, Odena G, Stevens SM, Jr. and You M, 2014. Deletion of SIRT1 from hepatocytes in mice disrupts lipin-1 signaling and aggravates alcoholic fatty liver. Gastroenterology, 146, 801-811. https://doi.org/10.1053/j.gastro.2013. 11.008

75) Yuan H, Wan J, Li L, Ge P, Li H and Zhang L, 2012. Therapeutic benefits of the group B3 vitamin nicotinamide in mice with lethal endotoxemia and polymicrobial sepsis. Pharmacological Research, 65, 328-337. https://doi.org/10.1016/j.phrs.2011.11.014

76) Zackrisson B, Franzen L, Henriksson R, Littbrand B, Stratford M, Dennis M, Rojas AM and Denekamp J, 1994. Acute effects of accelerated radiotherapy in combination with carbogen breathing and nicotinamide (ARCON). Acta Oncologica, 33, 377-381. https://doi.org/10. 3109/02841869409098432

77) Zhang C, Bjornson E, Arif M, Tebani A, Lovric A, Benfeitas R, Ozcan M, Juszczak K, Kim W, Kim JT, Bidkhori G, Stahlman M, Bergh PO, Adiels M, Turkez H, Taskinen MR, Bosley J, 
Marschall HU, Nielsen J, Uhlen M, Boren J and Mardinoglu A, 2020. The acute effect of metabolic cofactor supplementation: a potential therapeutic strategy against non-alcoholic fatty liver disease. Molecular Systems Biology, 16, e9495. https://doi.org/10.15252/msb. 209495

78) Zhang $Y, M a ~ T$ and Zhang $P, 2018$. Efficacy and safety of nicotinamide on phosphorus metabolism in hemodialysis patients: A systematic review and meta-analysis. Medicine (Baltimore), 97, e12731. https://doi.org/10.1097/MD.0000000000012731 


\section{Appendix C - Animal experiments on nicotinamide effect on chemical- and UV-induced tumours}

Adapted from Surjana et al. (2010) and Hwang and Song, (2020).

\begin{tabular}{|c|c|c|c|c|c|c|}
\hline Authors & Year & Species & Carcinogen & Form of nicotinamide (dose) & Organ & $\begin{array}{l}\text { Effect on } \\
\text { tumour }\end{array}$ \\
\hline Rosenberg et al. (1985) & 1985 & Rat & Diethylnitrosamine (DEN) & Oral $(0.082 \% ; 0.37 \%)$ & Kidney & Increase \\
\hline Kim et al. $(2011 a, b)$ & 2011 & Mouse & $\begin{array}{l}\text { N-butyl-N-(4-hydroxybutyl)- } \\
\text { nitrosamine (BBN) }\end{array}$ & $\begin{array}{l}\text { Oral }(0.1 \% ; 0.25 \% ; 0.5 \% ; 1 \% \text {; } \\
\text { drinking water) }\end{array}$ & Bladder & Inhibition \\
\hline Roe (1962) & 1962 & Mouse & DMBA and croton oil & Oral $(0.2 \%$ diet $)$ & Skin & None \\
\hline \multirow[t]{2}{*}{ French (1977) } & \multirow[t]{2}{*}{1978} & \multirow[t]{2}{*}{ Mouse } & \multirow[t]{2}{*}{ Urethane } & Oral $(0.25 \% ; 0.4 \%$ diet $)$ & Lung & Inhibition \\
\hline & & & & Oral (niacin; $0,25 \%$ diet) & Lung & None \\
\hline Bartleman et al. (2008) & 2008 & Rat & Ethylnitrosourea & Oral (niacin; $0.4 \%$ diet) & Bone marrow (haemopoietic cells) & Inhibition \\
\hline \multirow[t]{2}{*}{ Pamukcu et al. (1981) } & \multirow[t]{2}{*}{1981} & \multirow[t]{2}{*}{ Rat } & \multirow[t]{2}{*}{ Bracken fern } & \multirow[t]{2}{*}{ Oral $(0.5 \%$ diet $)$} & Intestine & Inhibition \\
\hline & & & & & Bladder & Inhibition \\
\hline Gensler et al. (1999) & 1999 & Mouse & UVB & Oral (niacin; $0.5 \% ; 1 \%$ diet) & Skin & Inhibition \\
\hline Gotoh et al. (1988) & 1988 & Mouse & Urethane & Oral (1\%; $2.5 \%$ diet) & Lung & Inhibition \\
\hline Gotoh et al. (1993) & 1993 & Mouse & $\begin{array}{l}\text { Transplanted murine breast } \\
\text { adenocarcinoma }\end{array}$ & Oral $(2.5 \% ; 5 \%)$ & Recipient subcutaneous tissue & Inhibition \\
\hline $\begin{array}{l}\text { Schmahl and Stackelberg } \\
\text { (1968) }\end{array}$ & 1968 & Rat & Diethylnitrosamine (DEN) & Oral (200 mg/kg; drinking water) & Liver & None \\
\hline Pour and Lawson (1984) & 1984 & Hamster & $\begin{array}{l}\text { N-nitrosobis(2-oxopropyl) } \\
\text { amine (BOP) }\end{array}$ & IP (30 mg/kg bw) & Pancreas & Inhibition \\
\hline Al-Gayyar et al. (2019) & 2019 & Rats & Thioacetamide & IP $(30 \mathrm{mg} / \mathrm{kg})$ & Liver & Inhibition \\
\hline Rakieten et al. (1971) & 1971 & Rat & Streptozotocin & IP (350 mg/kg bw) & Pancreas & Increase \\
\hline Rakieten et al. (1976) & 1976 & Rat & Streptozotocin & IP (350 mg/kg bw) & Kidney & Inhibition \\
\hline \multirow[t]{2}{*}{ Schoental (1977) } & \multirow[t]{2}{*}{1977} & \multirow[t]{2}{*}{ Rat } & \multirow[t]{2}{*}{ Diethylnitrosamine (DEN) } & \multirow[t]{2}{*}{ IP $(350-500 \mathrm{mg} / \mathrm{kg} \mathrm{bw})$} & Kidney & Increase \\
\hline & & & & & Liver & Inhibition \\
\hline Horsman et al. (1995) & 1995 & Mouse & $\begin{array}{l}\text { Transplanted murine breast } \\
\text { adenocarcinoma }\end{array}$ & IP $(1,000 \mathrm{mg} / \mathrm{kg} \mathrm{bw})$ & Recipient subcutaneous tissue & Inhibition \\
\hline Gensler (1997) & 1997 & Mouse & UV & Topical (200 nM) & Skin & Inhibition \\
\hline Ludwig et al. (1990) & 1990 & Mouse & $\begin{array}{l}\text { 12-O-tetradecanoylphorbol- } \\
\text { 13-acetate (TPA) }\end{array}$ & Topical $(150 \mu \mathrm{M})$ & Skin & Inhibition \\
\hline
\end{tabular}




\section{Appendix D - Benchmark dose modelling reports with a 5\% BMR}

\section{D.1. Body weight}

\section{Marinescu et al. (2020)}

\section{A. Data description}

The endpoint analysed was terminal body weight in male rats. The BMD analysis was performed using summary data as reported below.

\begin{tabular}{|c|c|c|c|}
\hline Dose & Mean body weight (males, g) & SD & $\mathbf{N}$ \\
\hline $\mathbf{0}$ & 534.3 & 72.4 & 10 \\
\hline 300 & 518.6 & 39.2 & 10 \\
\hline 500 & 506.1 & 39.4 & 10 \\
\hline 1,200 & 463.6 & 40.3 & 10 \\
\hline
\end{tabular}

\section{B. Selection of the BMR}

The BMR (benchmark response) used is a $5 \%$ change in mean response compared to the controls. The BMD (benchmark dose) is the dose corresponding with the BMR of interest. A $90 \%$ confidence interval around the BMD was estimated; the lower bound is reported by BMDL and the upper bound by BMDU.

\section{Software used}

Results are obtained using the EFSA web-tool for BMD analysis, which uses the R-package PROAST, version 69.0 , for the underlying calculations.

\section{Results}

Fitted models

\begin{tabular}{|c|c|c|c|}
\hline Model & Log-likelihood & Number of parameters & AIC \\
\hline full model & 38.76 & 5 & -67.52 \\
\hline null model & 33.26 & 2 & -62.52 \\
\hline Expon. m3- & 38.76 & 4 & -69.52 \\
\hline Expon. m5- & 38.76 & 5 & -67.52 \\
\hline Hill m3- & 38.76 & 4 & -69.52 \\
\hline Hill m5- & 38.76 & 5 & -67.52 \\
\hline Inv.Expon. m3- & 38.76 & 4 & -69.52 \\
\hline Inv.Expon. m5- & 38.76 & 5 & -67.52 \\
\hline LN m3- & 38.76 & 4 & -69.52 \\
\hline LN m5- & 38.76 & 5 & -67.52 \\
\hline
\end{tabular}

Estimated model parameters

\begin{tabular}{l|c|c|c|c}
\hline Estimate & EXP & HILL & INVEXP & LOGN \\
\hline var- & 0.00843 & 0.00843 & 0.008429 & 0.008429 \\
\hline a- & 529.7 & 529.7 & 529.5 & 529.6 \\
\hline CED- & 534.6 & 534.5 & 526.4 & 529.9 \\
\hline d- & 1.217 & 1.219 & 0.1921 & 0.3796 \\
\hline
\end{tabular}


Weights for Model Averaging

\begin{tabular}{l|ccc}
\hline EXP & HILL & INVEXP & LOGN \\
\hline 0.25 & 0.25 & 0.25 & 0.25 \\
\hline
\end{tabular}

Final BMD Values

\begin{tabular}{l|c|c}
\hline Endpoint & BMDL & BMDU \\
\hline Absolute body weight $(\mathrm{g})$ & 104 & 1,110 \\
\hline
\end{tabular}

Confidence intervals for the BMD are based on 200 bootstrap data sets.

\section{E. Visualisation}
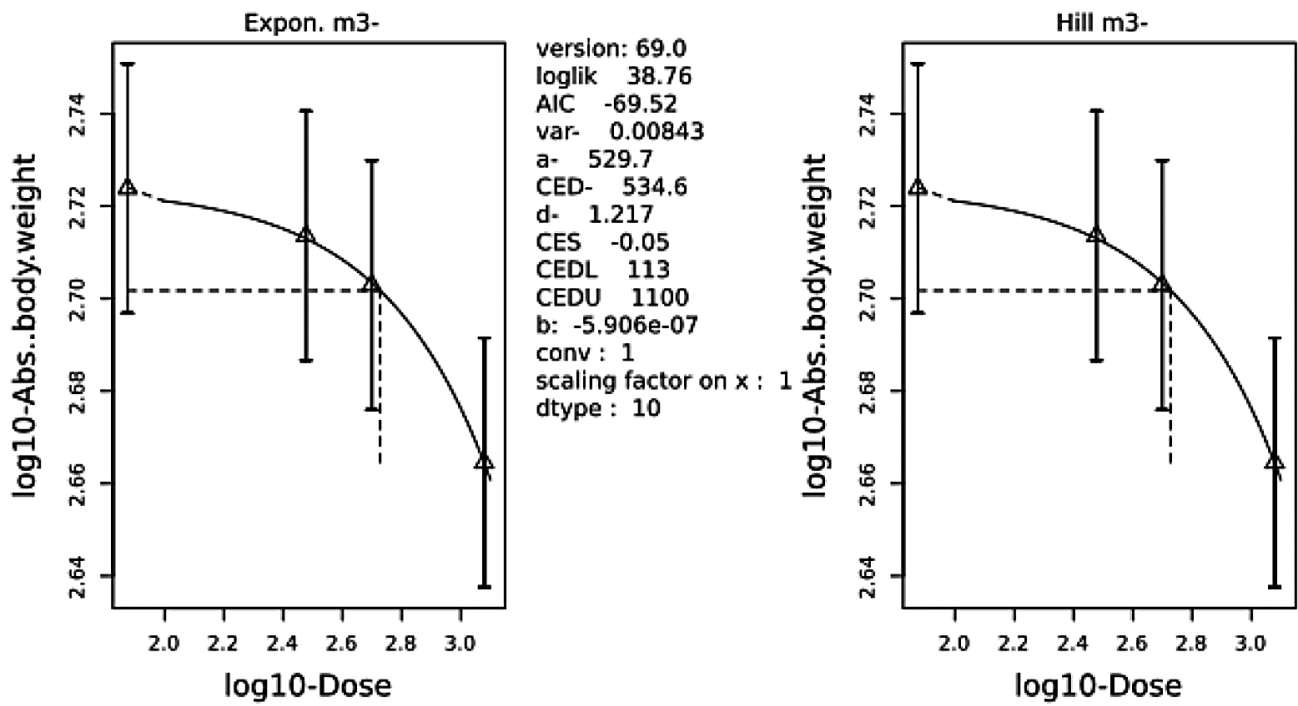

version: 69.0

version: 69.0

Ioglik 38.76

AIC -69.52

var- 0.00843

a- 529.7

CED- 534.6

d. 1.217

CES -0.05

CEDL 113

CEDU 1100

b: $-5.906 \mathrm{e}-07$

conv: 1

scaling factor on $x$ :

dtype: 10

oglik 38.76

AIC -69.52

var- 0.00843

a- 529.7

CED- 534.5

d. 1.219

CES -0.05

CEDL 113

CEDU 1100

b: 135300

conv: 1

scaling factor on $x: 1$

dtype : 10
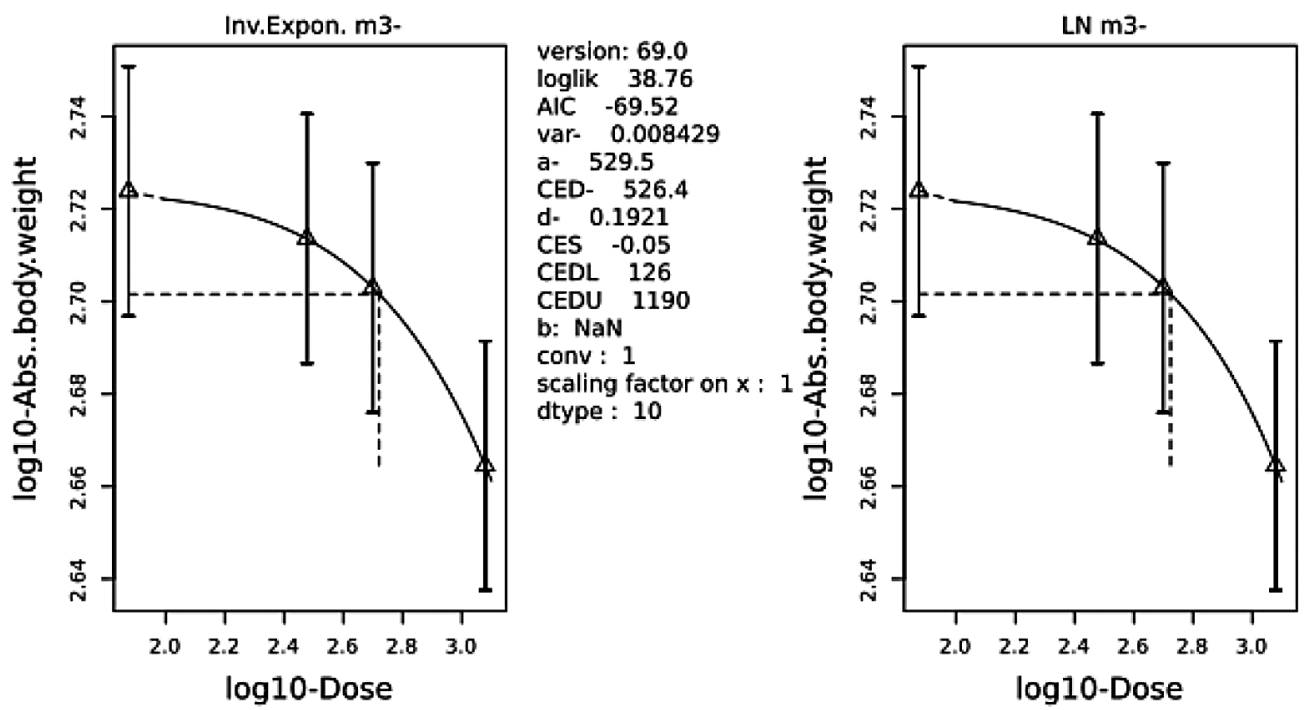

version: 69.0

oglik 38.76

version: 69.0

loglik 38.76

AIC -69.52

var- 0.008429

a- $\mathbf{5 2 9 . 5}$

CED- 526.4

d. 0.1921

CES $\quad-0.05$

CEDL 126

CEDU 1190

b: NaN

conv: 1

scaling factor on $x$ :

dtype : 10

AIC -69.52

var- 0.008429

a- 529.6

CED- 529.9

d. 0.3796

CES -0.05

CEDL 120

CEDU 1140

b: NaN

conv: 1

caling factor on $x$ : 1

dtype : 10

Figure D.1: Visualisation of the individual BMD model curves 


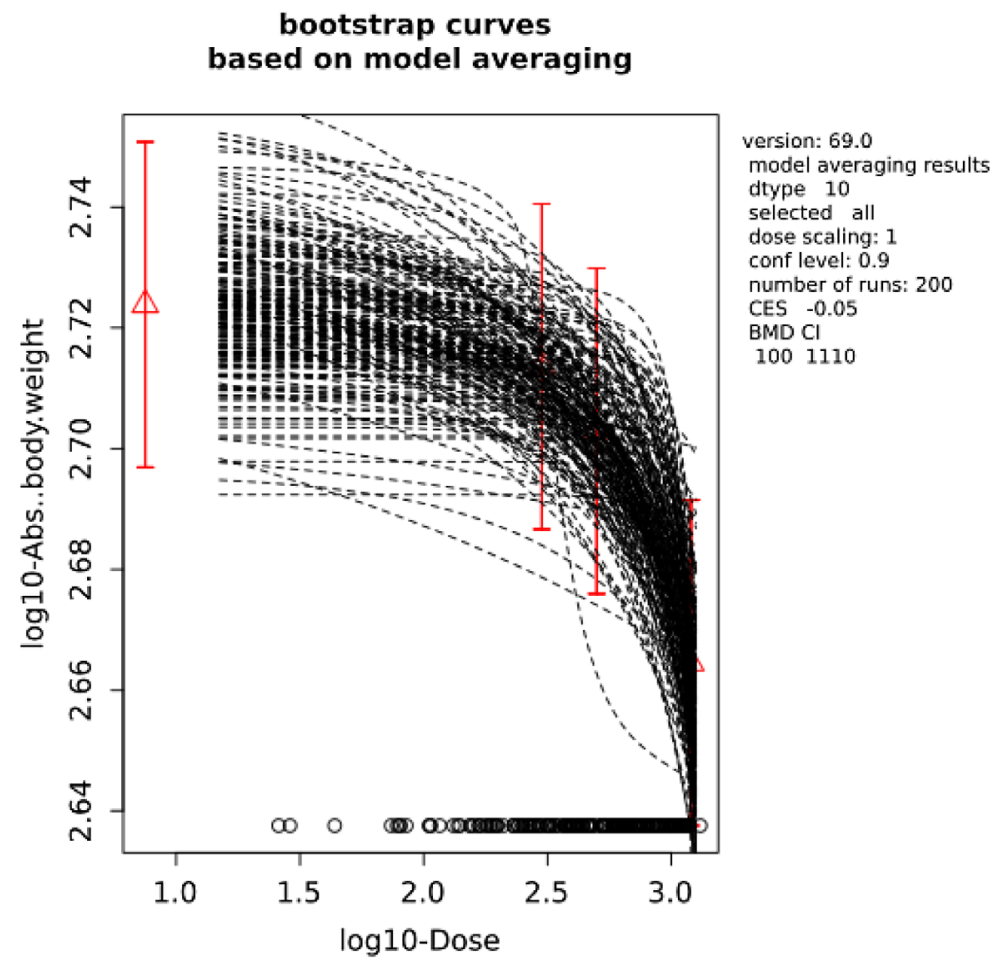

Figure D.2: Visualisation of bootstrap curves based on BMD model averaging

\section{F. Conclusions}

Conclusions on the BMD modelling are discussed in the opinion.

II. Conze et al. (2016)

\section{A. Data description}

The endpoint analysed was terminal body weight in male and female rats. The BMD analysis was performed using summary data as reported below.

\begin{tabular}{l|l|r|r|l}
\hline Dose & Sex & Mean body weight, $\mathbf{g}$ & SD & N \\
\hline $\mathbf{0}$ & M & 395.70 & 18.36 & 10 \\
\hline $\mathbf{3 0 0}$ & M & 363.56 & 23.22 & 10 \\
\hline $\mathbf{1 , 0 0 0}$ & M & 354.22 & 21.86 & 10 \\
\hline $\mathbf{3 , 0 0 0}$ & M & 317.21 & 25.80 & 10 \\
\hline $\mathbf{0}$ & F & 232.29 & 8.10 & 10 \\
\hline $\mathbf{3 0 0}$ & F & 234.43 & 23.28 & 10 \\
\hline $\mathbf{1 , 0 0 0}$ & F & 219.51 & 9.92 & 10 \\
\hline $\mathbf{3 , 0 0 0}$ & F & 216.19 & 14.75 & 10 \\
\hline
\end{tabular}

\section{B. Selection of the BMR}

The BMR (benchmark response) used is a $5 \%$ change in mean response compared to the controls. The BMD (benchmark dose) is the dose corresponding with the BMR of interest. A $90 \%$ confidence interval around the BMD will be estimated, the lower bound is reported by BMDL and the upper bound by BMDU.

\section{Software used}

Results are obtained using the EFSA web-tool for BMD analysis, which uses the R-package PROAST, version 69.0 , for the underlying calculations. 


\section{Results}

Fitted models

\begin{tabular}{l|c|c|c}
\hline Model & Log-likelihood & Number of parameters & AIC \\
\hline full model & 108.75 & 9 & -199.50 \\
\hline full-v & 108.77 & 10 & -197.54 \\
\hline null model & -1.10 & 2 & 6.20 \\
\hline null model-a & 81.49 & 3 & -156.98 \\
\hline Expon. m3- & 0.96 & 4 & 6.08 \\
\hline Expon. m3-a & 101.70 & 5 & -193.40 \\
\hline Expon. m3-ab & 107.00 & 6 & -202.00 \\
\hline Expon. m5-a & 101.72 & 6 & -191.44 \\
\hline Expon. m5-ab & 107.00 & 7 & -200.00 \\
\hline Hill m3-a & 101.70 & 5 & -193.40 \\
\hline Hill m3-ab & 107.00 & 6 & -202.00 \\
\hline Hill m5-a & 101.72 & 6 & -191.44 \\
\hline Hill m5-ab & 107.00 & 7 & -200.00 \\
\hline Inv.Expon. m3-a & 101.72 & 5 & -193.44 \\
\hline Inv.Expon. m3-ab & 106.98 & 6 & -201.96 \\
\hline Inv.Expon. m5-a & 101.72 & 6 & -191.44 \\
\hline Inv.Expon. m5-ab & 106.96 & 7 & -199.92 \\
\hline LN m3-a & 101.71 & 5 & -193.42 \\
\hline LN m3-ab & 106.99 & 6 & -201.98 \\
\hline LN m5-a & 101.72 & 6 & -191.44 \\
\hline LN m5-ab & 106.99 & 7 & -199.98 \\
\hline
\end{tabular}

Estimated model parameters

\begin{tabular}{l|c|c|c|c}
\hline Estimate & EXP & HILL & INVEXP & LOGN \\
\hline var- & 0.004034 & 0.004034 & 0.004037 & 0.004035 \\
\hline a-f & 234 & 234 & 233.6 & 233.8 \\
\hline a-m & 393.4 & 393.4 & 393.9 & 393.7 \\
\hline CED-f & 1,144 & 1,145 & 1,238 & 1,199 \\
\hline CED-m & 189.5 & 189.6 & 192.2 & 191.5 \\
\hline d- & 0.5198 & 0.5206 & 0.08739 & 0.1681 \\
\hline
\end{tabular}

Weights for Model Averaging

\begin{tabular}{l|c|c|c}
\hline EXP & HILL & INVEXP & LOGN \\
\hline 0.25 & 0.25 & 0.25 & 0.25 \\
\hline
\end{tabular}

Final BMD Values

\begin{tabular}{l|l|c|c}
\hline Endpoint & Subgroup & BMDL & BMDU \\
\hline Absolute body weight & M & 54.6 & 563 \\
\hline Absolute body weight & F & 510.0 & 5,400 \\
\hline
\end{tabular}

Confidence intervals for the BMD are based on 200 bootstrap data sets. 


\section{E. Visualisation}

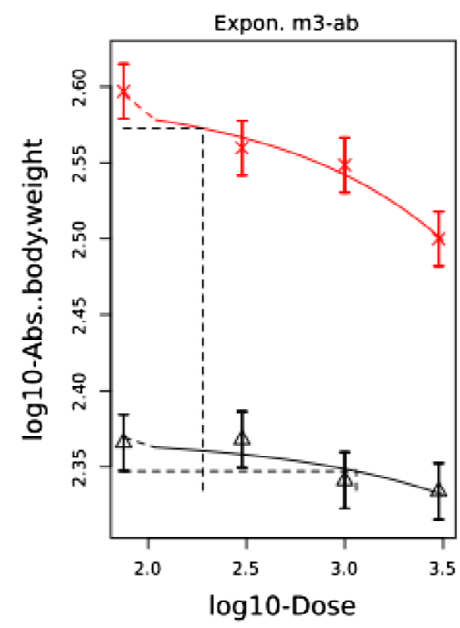

version: 69.0 loglik 107

AIC -202 var- 0.004034

a-f 234

a-m 393.4

CED-f 1144

CED-m 189.5

d. 0.5198

$\begin{array}{lr}\text { CES } & -0.05\end{array}$

CES ${ }^{-0.05}$

CEDU-f 5130

$\begin{array}{cc}\text { CEDU-f } & 5130 \\ \text { CEDL-m } & 37\end{array}$

CEDU-m 584

b: $-3.181 \mathrm{e}-05$

b: $-8.098 \mathrm{e}-05$

conv: 1

dtype : 10

covariate: Sex

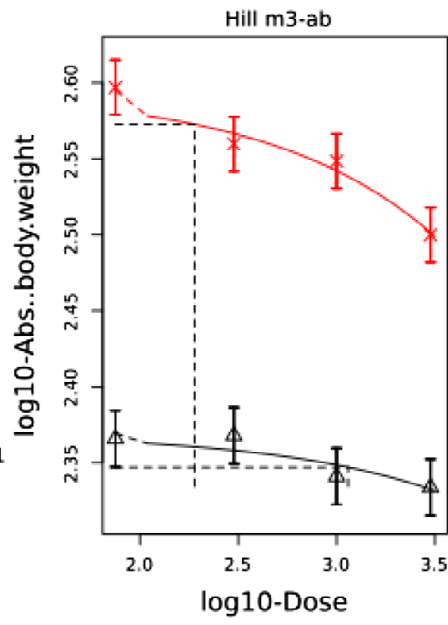

ersion: 69.0

loglik 107

AIC -202

var- 0.004034

a-f 234

a-m 393.4

CED-m 1145

CED-m 189.
d. 0.5206

d. 0.5206

CES -0.05

CEDL-f 5140

CEDU-f 5140

CEDL-m 37

CEDU-m 584

b: 483800000

b: 80140000

conv: 1

scaling factor on $x: 1$

dtype: 10

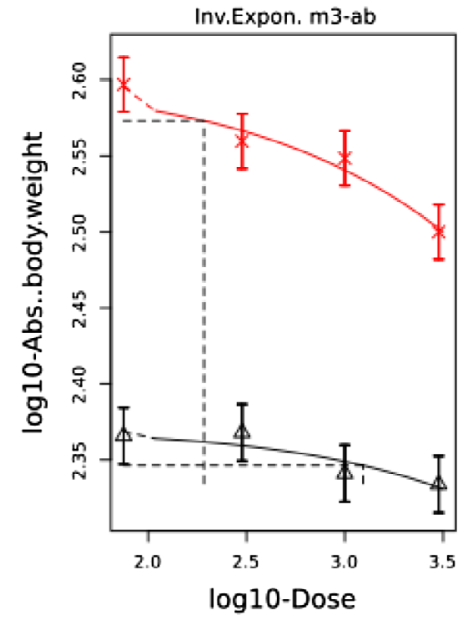

version: 69.0 loglik 106.98 AIC -201.96 $\begin{array}{ll}\text { Alc } & -201.96 \\ \text { var- } 0.004037\end{array}$ a-f 233.6 $\begin{array}{lr}\text { a-f } & 233.6 \\ \text { a-m } & 393.9\end{array}$ a-m 393.9 CED-f 1238 CED-m 192.2 d. 0.08739 CES -0.05 CEDL-f 418 CEDU-f 4710 CEDL-m 43

CEDU-m 553

b: $\mathrm{NaN}$

b: $\mathrm{NaN}$

conv: 1

dtype : 10

covariate: Sex

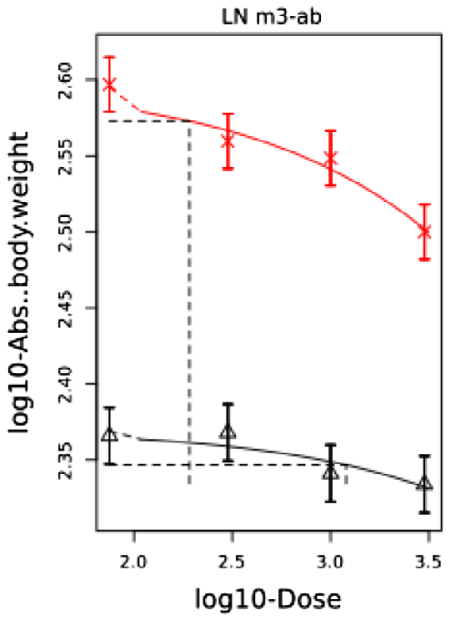

version: 69.0 loglik 106.99 AIC -201.98

a 233.8

a-f 233.8

a-m 393.7

CED-f 1199

CED-m 191.5

d. 0.1681

CES -0.05

$\begin{array}{ll}\text { CEDL-f } & 391 \\ \text { CEDU- } & 4880\end{array}$

CEDL-m 40.6

CEDU-m 571

b: $\mathrm{NaN}$

b: $\mathrm{NaN}$

scaling factor on $x$ :

dtype: 10

covariate: Sex

Figure D.3: Visualisation of the individual BMD model curves 


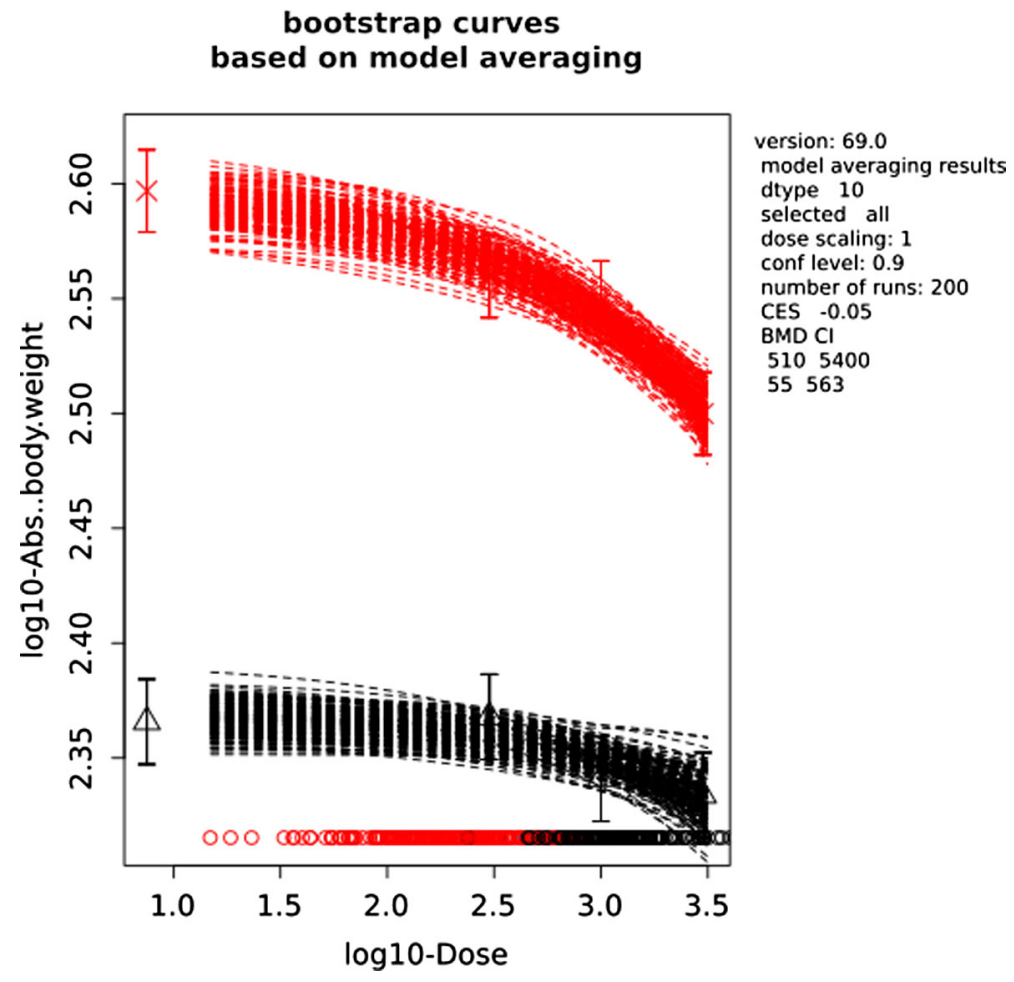

Figure D.4: Visualisation of bootstrap curves based on BMD model averaging

\section{F. Conclusions}

Conclusions on the BMD modelling are discussed in the opinion.

\section{D.2. Relative liver weight (Conze et al., 2016)}

\section{A. Data description}

The endpoint analysed was terminal liver weight relative to body weight in male and female rats. The BMD analysis was performed using summary data as reported below.

\begin{tabular}{l|l|l|l|l}
\hline Dose & Sex & Relative liver weight & SD & N \\
\hline $\mathbf{0}$ & M & 2.958 & 0.143 & 10 \\
\hline $\mathbf{3 0 0}$ & M & 3.013 & 0.163 & 10 \\
\hline $\mathbf{1 , 0 0 0}$ & M & 3.200 & 0.180 & 10 \\
\hline $\mathbf{3 , 0 0 0}$ & M & 3.600 & 0.272 & 10 \\
\hline $\mathbf{0}$ & F & 2.902 & 0.191 & 10 \\
\hline $\mathbf{3 0 0}$ & F & 3.003 & 0.327 & 10 \\
\hline $\mathbf{1 , 0 0 0}$ & F & 3.295 & 0.181 & 10 \\
\hline $\mathbf{3 , 0 0 0}$ & F & 4.046 & 0.174 & 10 \\
\hline
\end{tabular}

\section{B. Selection of the BMR}

The BMR (benchmark response) used is a $5 \%$ change in mean response compared to the controls. The BMD (benchmark dose) is the dose corresponding with the BMR of interest. A $90 \%$ confidence interval around the BMD will be estimated; the lower bound is reported by BMDL and the upper bound by BMDU.

\section{Software used}

Results are obtained using the EFSA web-tool for BMD analysis, which uses the R-package PROAST, version 69.0 , for the underlying calculations. 


\section{Results}

Fitted models

\begin{tabular}{|c|c|c|c|}
\hline Model & Log-likelihood & Number of parameters & AIC \\
\hline full model & 107.88 & 9 & -197.76 \\
\hline full-v & 108.66 & 10 & -197.32 \\
\hline null model & 52.96 & 2 & -101.92 \\
\hline null model-a & 53.55 & 3 & -101.10 \\
\hline Expon. m3- & 98.97 & 4 & -189.94 \\
\hline Expon. m3-a & 100.84 & 5 & -191.68 \\
\hline Expon. m3-b & 107.00 & 5 & -204.00 \\
\hline Expon. m3-ab & 107.65 & 6 & -203.30 \\
\hline Expon. m5- & 99.14 & 5 & -188.28 \\
\hline Expon. m5-a & 101.03 & 6 & -190.06 \\
\hline Expon. m5-b & 107.00 & 6 & -202.00 \\
\hline Expon. m5-ab & 107.72 & 7 & -201.44 \\
\hline Hill m3- & 98.97 & 4 & -189.94 \\
\hline Hill m3-a & 100.84 & 5 & -191.68 \\
\hline Hill m3-b & 107.00 & 5 & -204.00 \\
\hline Hill m3-ab & 107.65 & 6 & -203.30 \\
\hline Hill m5- & 99.14 & 5 & -188.28 \\
\hline Hill m5-a & 101.03 & 6 & -190.06 \\
\hline Hill m5-b & 107.00 & 6 & -202.00 \\
\hline Hill m5-ab & 107.73 & 7 & -201.46 \\
\hline Inv.Expon. m3- & 99.11 & 4 & -190.22 \\
\hline Inv.Expon. m3-a & 100.99 & 5 & -191.98 \\
\hline Inv.Expon. m3-b & 106.95 & 5 & -203.90 \\
\hline Inv.Expon. m3-ab & 107.76 & 6 & -203.52 \\
\hline Inv.Expon. m5- & 99.14 & 5 & -188.28 \\
\hline Inv.Expon. m5-a & 101.03 & 6 & -190.06 \\
\hline Inv.Expon. m5-b & 106.90 & 6 & -201.80 \\
\hline Inv.Expon. m5-ab & 107.75 & 7 & -201.50 \\
\hline LN m3- & 99.06 & 4 & -190.12 \\
\hline LN m3-a & 100.94 & 5 & -191.88 \\
\hline LN m3-b & 106.99 & 5 & -203.98 \\
\hline LN m3-ab & 107.74 & 6 & -203.48 \\
\hline LN m5- & 99.14 & 5 & -188.28 \\
\hline LN m5-a & 101.03 & 6 & -190.06 \\
\hline LN m5-b & 106.98 & 6 & -201.96 \\
\hline LN m5-ab & 107.76 & 7 & -201.52 \\
\hline
\end{tabular}

\section{Estimated model parameters}

\begin{tabular}{l|c|c|c|c}
\hline Estimate & EXP & HILL & INVEXP & LOGN \\
\hline var- & 0.004035 & 0.004035 & 0.00404 & 0.004035 \\
\hline a- & 2.922 & 2.922 & 2.929 & 2.926 \\
\hline CED-f & 387.3 & 387.6 & 424.1 & 408.3 \\
\hline CED-m & 614.6 & 615.3 & 692.5 & 659 \\
\hline d- & 0.925 & 0.927 & 0.1666 & 0.3111 \\
\hline
\end{tabular}


Weights for Model Averaging

\begin{tabular}{l|c|c|c}
\hline EXP & HILL & INVEXP & LOGN \\
\hline 0.25 & 0.25 & 0.24 & 0.25 \\
\hline
\end{tabular}

Final BMD Values

\begin{tabular}{l|l|c|c}
\hline Endpoint & Subgroup & BMDL & BMDU \\
\hline Relative liver weight & M & 399 & 1,120 \\
\hline Relative liver weight & $\mathrm{F}$ & 226 & 721 \\
\hline
\end{tabular}

Confidence intervals for the BMD are based on 200 bootstrap data sets.

\section{E. Visualisation}

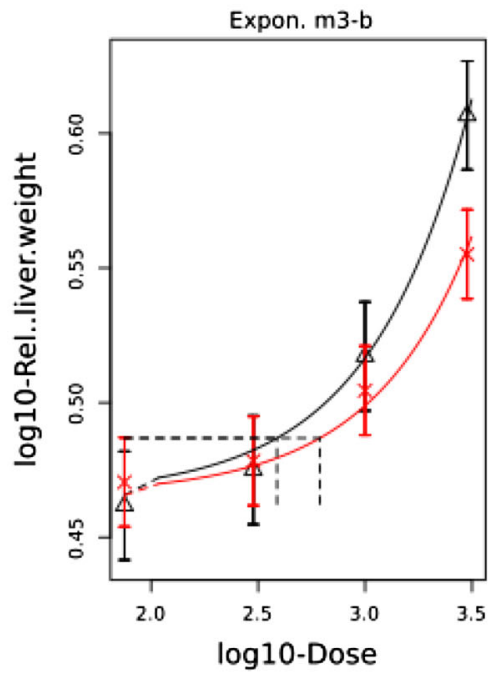

version: 69.0

loglik 107

$\begin{array}{ll}\text { AlC } & -204 \\ \text { var- } & 0.004035\end{array}$

a. 2.922

CED-f 387.3

CED-m 614.6

d- 0.925

CES 0.05

CEDL-f 208

CEDU-f 660

CEDL-m 349

CEDU-m 987

b: $4.755 \mathrm{e}-06$

b: $3.102 \mathrm{e}-06$

conv: 1

scaling factor on $x$ : 1 으

dtype : 10

covariate: Sex

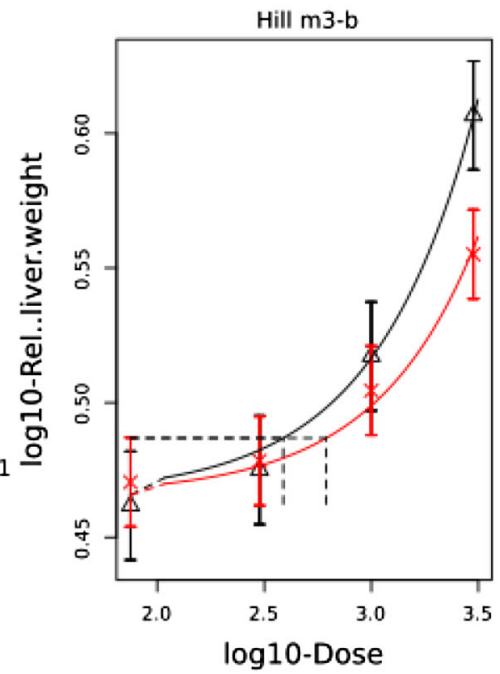

version: 69.0

loglik 107

AIC -204

var- 0.004035

a- 2.922

CED-f 387.6

CED-m 615.3

d- 0.927

CES 0.05

CEDL-f 208

CEDU-f 660

CEDL-m 349

CEDU-m 988

b: 559400

b: 888200

conv: 1

scaling factor on $x: 1$

dtype: 10

covariate: Sex

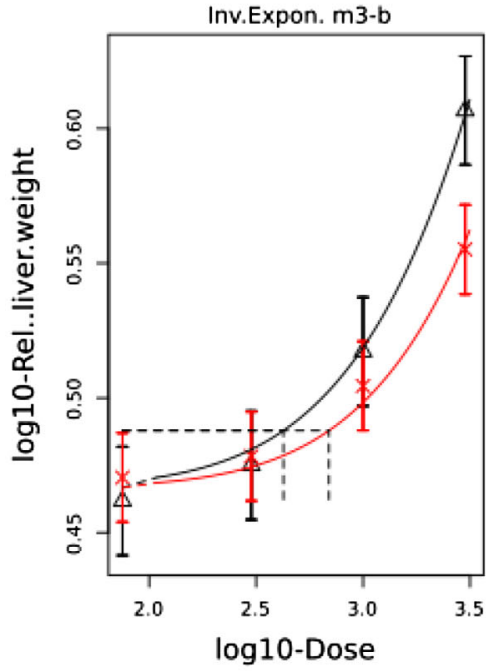

version: 69.0

loglik 106.95

AIC -203.9

var- 0.00404

a- 2.929

CED-f 424.1

CED-m 692.5

d- 0.1666

CES 0.05

CEDL-f 243

CEDU-f 683

CEDL-m 416

CEDU-m 1060

b: 18.48

b: 20.05

conv: 1

scaling factor on $x$ : 1 으

dtype : 10

covariate: Sex

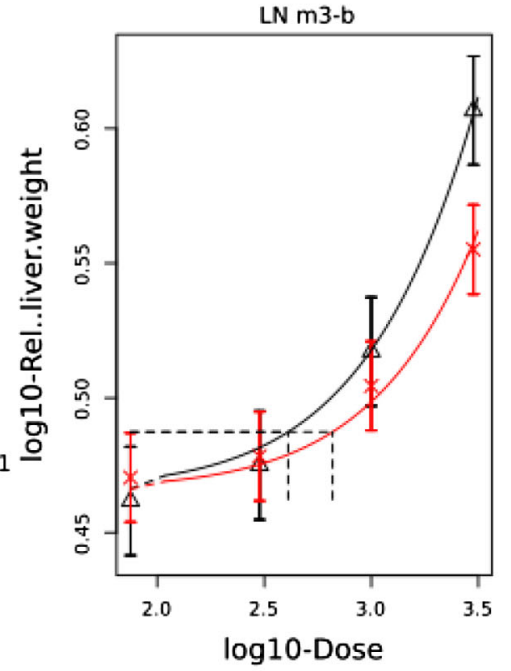

version: 69.0

loglik 106.99

AIC -203.98

var- 0.004035

a- 2.926

CED-f 408.3

CED-m 659

d- 0.3111

CES 0.05

CEDL- $f 228$

CEDU-f 673

CEDL-m 387

CEDU-m 1030

b: 0.007361

b: 0.006343

conv : 1

scaling factor on $x: 1$

dtype : 10

covariate: Sex

Figure D.5: Visualisation of the individual BMD model curves

\section{F. Conclusions}

Conclusions on the BMD modelling are discussed in the opinion. 


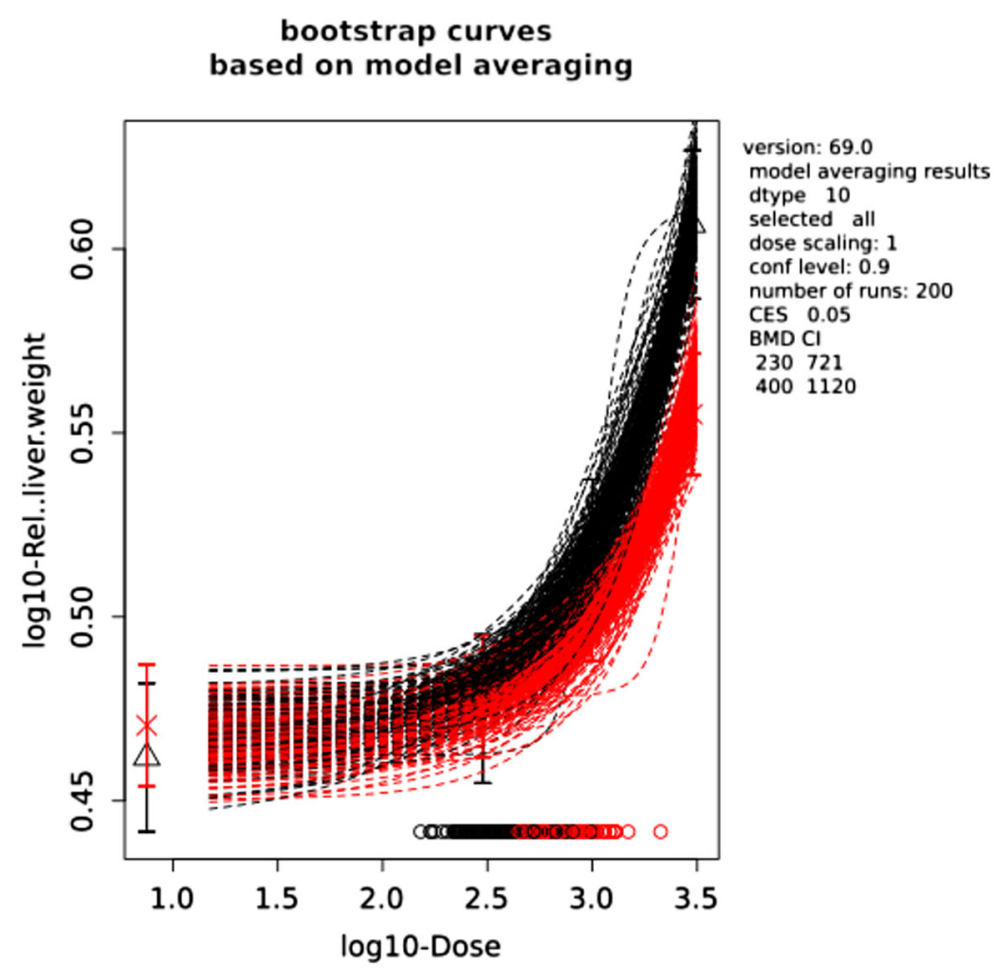

Figure D.6: Visualisation of bootstrap curves based on BMD model averaging

\section{D.3. Relative kidney weight (Conze et al., 2016)}

\section{A. Data description}

The endpoint analysed was terminal kidney weight relative to body weight in male and female rats. The BMD analysis was performed using summary data as reported below.

\begin{tabular}{l|l|l|l|l}
\hline Dose & Sex & Relative kidney weight & SD & N \\
\hline 0 & M & 0.715 & 0.047 & 10 \\
\hline 300 & M & 0.701 & 0.033 & 10 \\
\hline 1,000 & M & 0.777 & 0.020 & 10 \\
\hline 3,000 & M & 0.876 & 0.063 & 10 \\
\hline 0 & F & 0.676 & 0.053 & 10 \\
\hline 300 & F & 0.645 & 0.060 & 10 \\
\hline 1,000 & F & 0.678 & 0.058 & 10 \\
\hline 3,000 & F & 0.822 & 0.044 & 10 \\
\hline
\end{tabular}

\section{B. Selection of the BMR}

The BMR (benchmark response) used is a $5 \%$ change in mean response compared to the controls. The BMD (benchmark dose) is the dose corresponding with the BMR of interest. A $90 \%$ confidence interval around the BMD will be estimated, the lower bound is reported by BMDL and the upper bound by BMDU.

\section{Software used}

Results are obtained using the EFSA web-tool for BMD analysis, which uses the R-package PROAST, version 69.0, for the underlying calculations. 


\section{Results}

Fitted models

\begin{tabular}{l|c|c|c}
\hline Model & Log-likelihood & Number of parameters & AIC \\
\hline full model & 105.49 & 9 & -192.98 \\
\hline full-v & 107.90 & 10 & -195.80 \\
\hline null model-v & 56.90 & 3 & -107.80 \\
\hline null model-a-v & 62.48 & 4 & -116.96 \\
\hline Expon. m3-v & 89.66 & 5 & -169.32 \\
\hline Expon. m3-av & 102.57 & 6 & -193.14 \\
\hline Expon. m3-abv & 102.65 & 7 & -191.30 \\
\hline Expon. m5-av & 103.39 & 7 & -192.78 \\
\hline Expon. m5-abv & 103.60 & 8 & -191.20 \\
\hline Hill m3-av & 102.58 & 6 & -193.16 \\
\hline Hill m3-abv & 102.65 & 7 & -191.30 \\
\hline Hill m5-av & 103.98 & 7 & -193.96 \\
\hline Hill m5-abv & 105.00 & 8 & -194.00 \\
\hline Inv.Expon. m3-av & 103.12 & 6 & -194.24 \\
\hline Inv.Expon. m3-abv & 103.14 & 7 & -192.28 \\
\hline Inv.Expon. m5-av & 104.44 & 7 & -194.88 \\
\hline Inv.Expon. m5-abv & 105.81 & 8 & -195.62 \\
\hline LN m3-av & 102.88 & 6 & -193.76 \\
\hline LN m3-abv & 102.93 & 7 & -191.86 \\
\hline LN m5-av & 104.22 & 7 & -194.44 \\
\hline LN m5-abv & 105.03 & 8 & -194.06 \\
\hline
\end{tabular}

Estimated model parameters

\begin{tabular}{l|c|c|c|c}
\hline Estimate & EXP & HILL & INVEXP & LOGN \\
\hline var-f & 0.006255 & 0.00604 & 0.005994 & 0.006303 \\
\hline var-m & 0.003247 & 0.002978 & 0.002881 & 0.002967 \\
\hline a-f & 0.6508 & 0.6568 & 0.6593 & 0.6508 \\
\hline a-m & 0.7095 & 0.7004 & 0.7036 & 0.7095 \\
\hline CED- & 855.3 & N/A & N/A & 821.5 \\
\hline CED-f & N/A & 1045 & 1093 & N/A \\
\hline CED-m & N/A & 704.4 & 763.8 & N/A \\
\hline c- & N/A & 1.3 & 1.3 & 1.3 \\
\hline d- & 1.196 & 2.67 & 1.862 & 1.425 \\
\hline
\end{tabular}

Weights for Model Averaging

\begin{tabular}{|c|c|c|c|}
\hline EXP & HILL & INVEXP & LOGN \\
\hline 0.13 & 0.19 & 0.44 & 0.24 \\
\hline
\end{tabular}

Final BMD Values

\begin{tabular}{l|l|c|c}
\hline Endpoint & Subgroup & BMDL & BMDU \\
\hline Relative kidney weight & M & 425 & 1,040 \\
\hline Relative kidney weight & F & 427 & 1,410 \\
\hline
\end{tabular}

Confidence intervals for the BMD are based on 200 bootstrap data sets. 


\section{E. Visualisation}
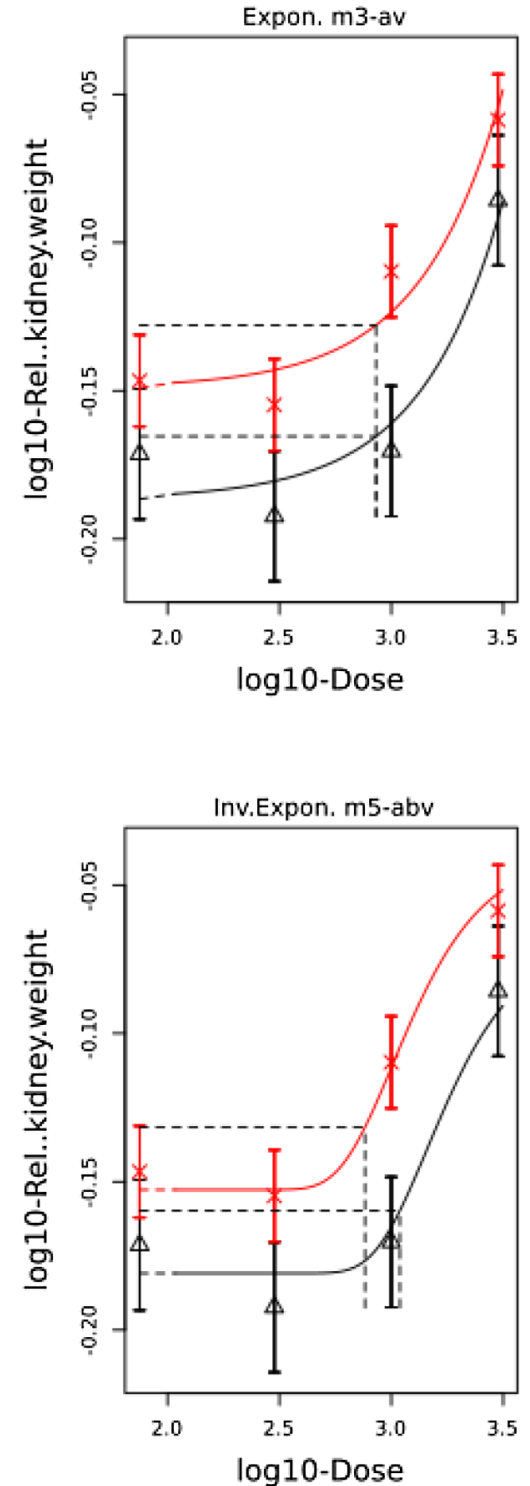

version: 69.0

loglik 102.57

AIC -193.14

var-f 0.006255

var-m 0.003247

a-f 0.6508

$\mathrm{a}=\mathrm{m} \quad 0.7095$

CED- 855.3

d- 1.196

CES 0.05

CEDL 506

CEDU 1340

b: $3.679 \mathrm{e}-07$

conv : 1

scaling factor on $x: 10$

dtype: 10

covariate: Sex

version: 69.0

loglik 105.81

AIC -195.62

var-f 0.005994

var-m 0.002881

a-f 0.6593

$\mathrm{a}-\mathrm{m} \quad 0.7036$

CED-f 1093

CED-m 763.8

c- 1.3

d- 1.862

CES 0.05

CEDL-f 776

CEDU-f 1570

CEDL-m 589

CEDU-m 940

b: 764600

b: 392300

conv: 1

scaling factor on $x: 1$

dtype: 10

covariate: Sex

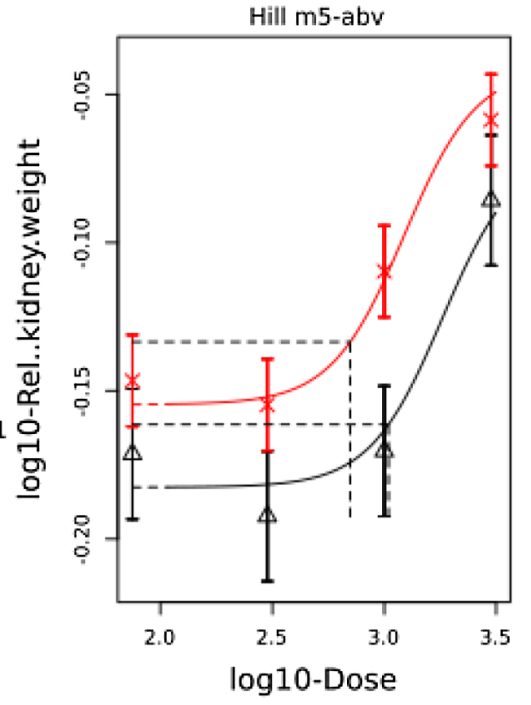

version: 69.0

loglik 105

AIC -194

var-f 0.00604

var-m $\quad 0.002978$

a-f 0.6568

$\mathrm{a}-\mathrm{m} \quad 0.7004$

CED-f 1045

CED-m 704.4

C- 1.3

d. 2.67

CES 0.05

CEDL-f 704

CEDU-f 1640

CEDL-m 528

CEDU-m 954

b: 1816

b: 1224

conv: 1

scaling factor on $x: 1$

dtype: 10

covariate: Sex

Figure D.7: Visualisation of the individual BMD model curves 


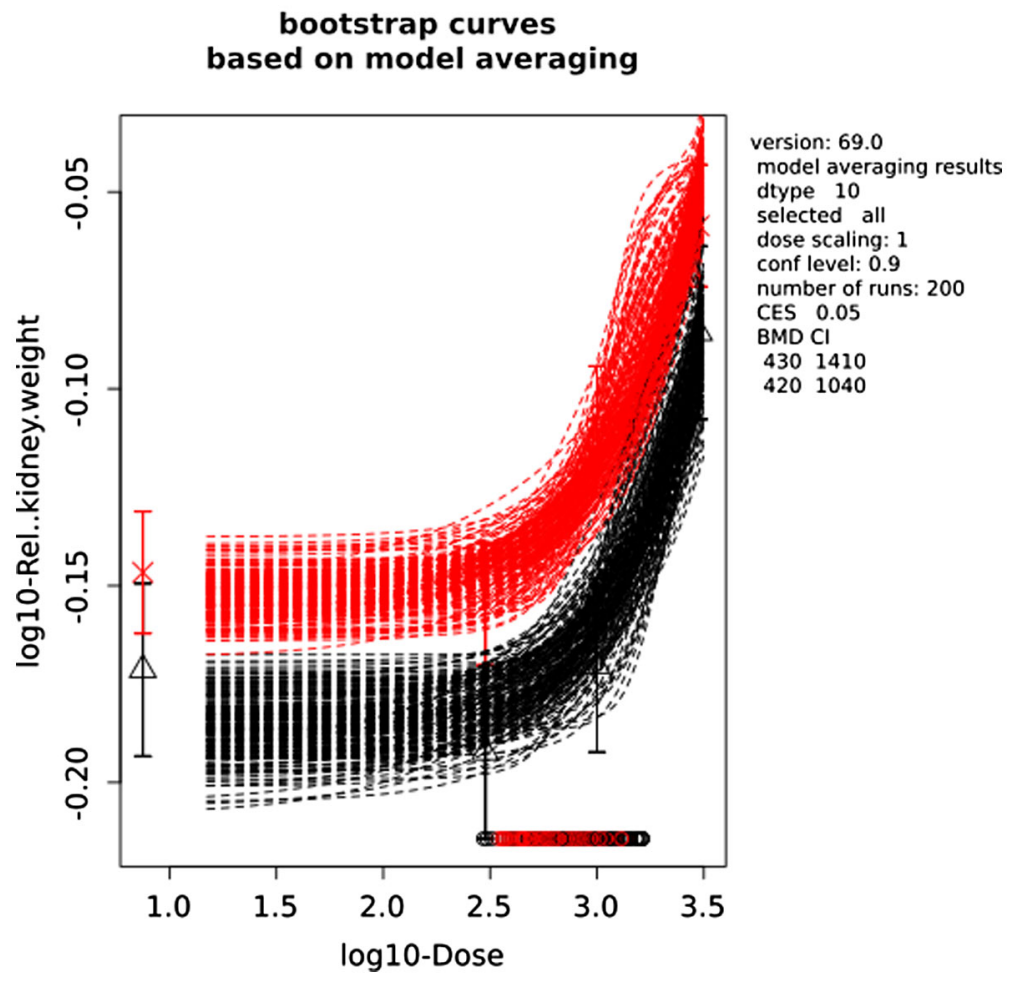

Figure D.8: Visualisation of bootstrap curves based on BMD model averaging

\section{F. Conclusions}

Conclusions on the BMD modelling are discussed in the opinion. 